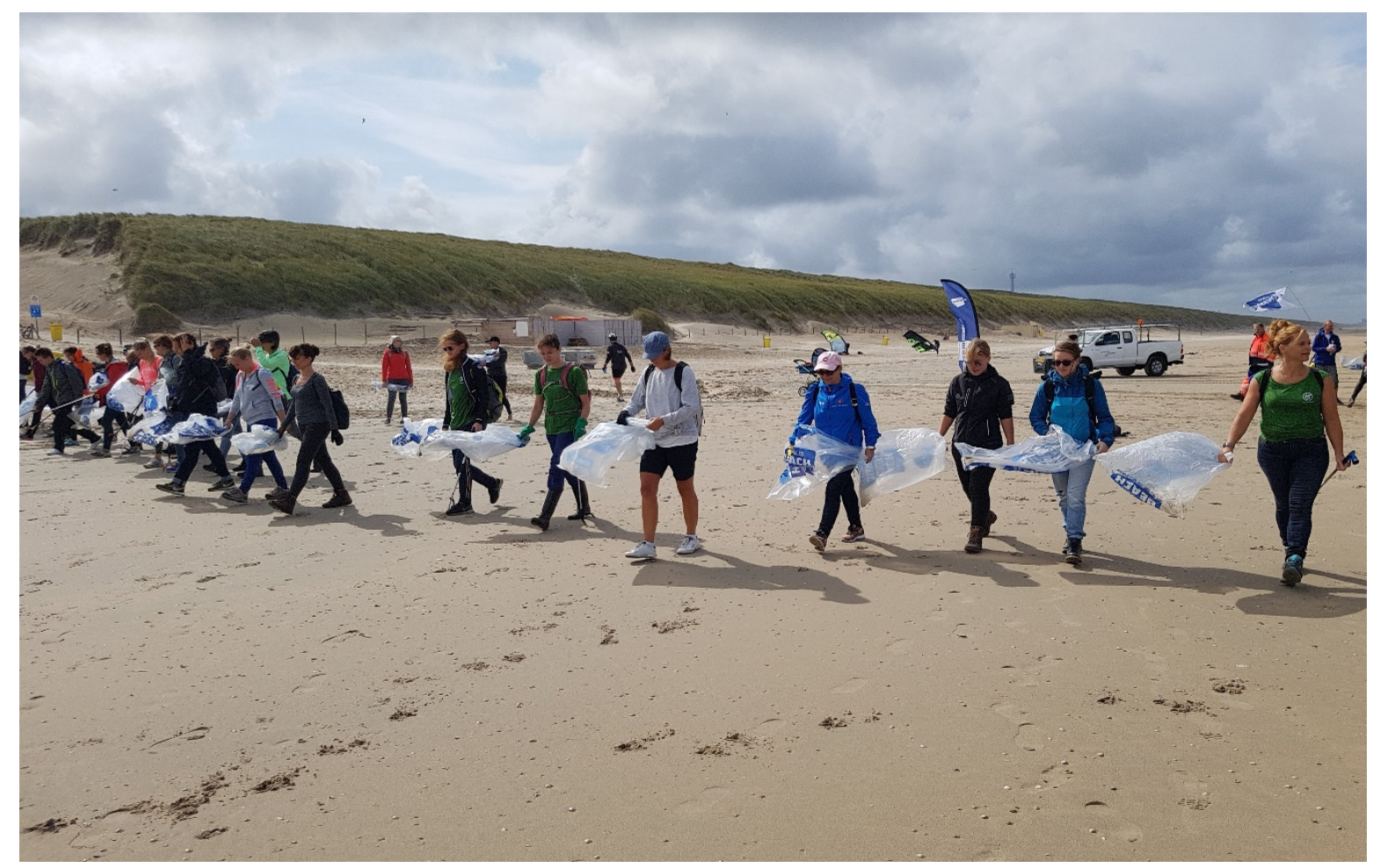

De kust opruimen met de Boskalis Beach Clean Up tour: Analyse van kenmerken en motivaties van deelnemers (2013-2019). 


\section{De kust opruimen met de Boskalis Beach Clean Up tour: Analyse van kenmerken en motivaties van deelnemers (2013-2019)}

Auteurs: Jacqueline Tamis, Susan de Koning

Dit project is uitgevoerd door Wageningen Marine Research als onderdeel van het Kennisbasis programma Natuurinclusieve Transities, project Citizens for Biodiversity (KB-36-005-001). 
Keywords: Boskalis Beach Clean Up Tour, plastic soep, zwerfafval, Noordzee, burgerbetrokkenheid, Stichting De Noordzee.

Opdrachtgever: Ministerie van Landbouw, Natuur en Voedselkwaliteit

Postbus 20401

2500 EK, Den Haag

Projectnummer: KB-36-005-001

Dit rapport is gratis te downloaden van https://doi.org/10.18174/521761.

Wageningen Marine Research verstrekt geen gedrukte exemplaren van rapporten.

Wageningen Marine Research is ISO 9001:2015 gecertificeerd.

Foto omslag: Stichting De Noordzee.

(C) Wageningen Marine Research

Wageningen Marine Research, instituut binnen de rechtspersoon Stichting Wageningen Research, hierbij vertegenwoordigd door Dr. M.C.Th. Scholten, Algemeen directeur

KvK nr. 09098104,

WMR BTW nr. NL 8113.83.696.B16.

Code BIC/SWIFT address: RABONL2U

IBAN code: NL 73 RABO 0373599285
Wageningen Marine Research aanvaardt geen aansprakelijkheid voor gevolgschade, noch voor schade welke voortvloeit uit toepassingen van de resultaten van werkzaamheden of andere gegevens verkregen van Wageningen Marine Research. Opdrachtgever vrijwaart Wageningen Marine Research van aanspraken van derden in verband met deze toepassing.

Alle rechten voorbehouden. Niets uit deze uitgave mag weergegeven en/of gepubliceerd worden, gefotokopieerd of op enige andere manier gebruikt worden zonder schriftelijke toestemming van de uitgever of auteur. 


\section{Inhoud}

Samenvatting

$\begin{array}{llr}1 & \text { Introductie } & 7\end{array}$

$\begin{array}{lll}1.1 & \text { Doel en kader } & 7\end{array}$

$\begin{array}{lll}1.2 & \text { Onderzoeksvragen } & 7\end{array}$

2 Methode $\quad 8$

2.1 Overzicht van alle gestelde vragen $\quad 8$

2.2 Selectie relevante vragen $\quad 8$

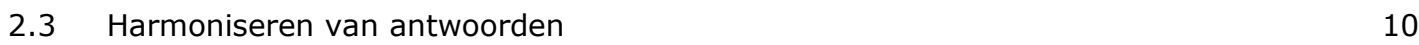

2.3.1 Persoonlijk 11

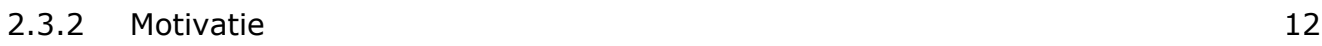

2.3.3 Waar/wanneer/hoe 15

$\begin{array}{ll}2.4 & \text { Extra vragen burgerbetrokkenheidsonderzoek } \\ \end{array}$

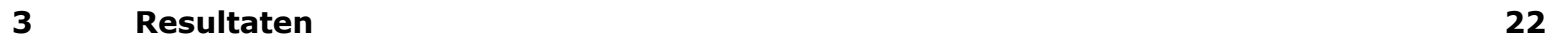

3.1 Aantal respondenten $\quad 22$

$\begin{array}{ll}3.2 & \text { Persoonlijk } \\ & 3.2 .12\end{array}$

$\begin{array}{lll}3.2 .1 & \text { Frequentie strandbezoek } & 23\end{array}$

3.2.2 Hobby's en aandacht voor milieu $\quad 23$

3.2.3 Werk en opleiding $\quad 24$

$\begin{array}{lll}3.2 .4 & \text { Media } & 24\end{array}$

$\begin{array}{ll}3.2 .5 & \text { Leeftijd, geslacht, gezinssituatie }\end{array}$

3.2.6 Woonplaats $\quad 28$

$\begin{array}{ll}3.3 \text { Waar/wanneer/hoe } & 29\end{array}$

$\begin{array}{lll}3.3 .1 & \text { Etappes } & 29\end{array}$

3.3.2 Reisafstand $\quad 32$

3.3.3 Speciaal er naartoe $\quad 33$

$\begin{array}{lll}3.3 .4 & \text { Vrij genomen van werk } & 34\end{array}$

3.3.5 Wijze van transport

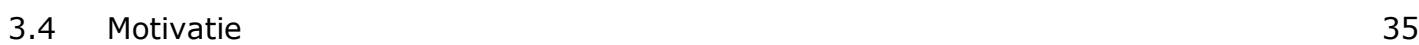

3.4.1 Aantal motivaties $\quad 35$

3.4.2 Type motivaties $\quad 36$

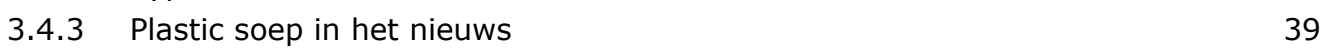

$\begin{array}{lll}3.4 .4 & \text { Invloed seizoen en weer } & 40\end{array}$

3.4.5 Volgend jaar weer? $\quad 41$

3.5 Extra vragen burgerbetrokkenheidsonderzoek (2019) 42

3.5.1 Betrokkenheid bij het milieu $\quad 42$

3.5.2 Verandering van gedrag na deelname $\quad 43$

3.5.3 Bijdrage Beach Clean-up aan verminderen plastic soep 43

$4 \quad$ Conclusies

4.1 Conclusies jaarlijkse deelnemers enquête 2013-2019 44

4.1.1 Wat voor type mensen doe mee met de Beach Clean-up? 44

4.1.2 Waar komen de deelnemers vandaan? 44

4.1.3 Welke etappes worden gelopen? $\quad 44$

4.1.4 Hoe ver reizen de deelnemers? $\quad 44$

4.1.5 Met welk vervoersmiddel? $\quad 45$

4.1.6 Zijn de deelnemers speciaal voor de Beach Clean-up gekomen? 45 
4.2 Extra vragen onderzoek Burgerbetrokkenheid

4.2.1 Betrokkenheid bij milieu naast deelname Clean-Up $\quad 45$

4.2.2 Verandering van gedrag met betrekking tot (zwerf)afval 46

4.2.3 Bijdrage aan oplossen van de plastic soep 46

$\begin{array}{lll}4.3 & \text { Aanbevelingen } & 46\end{array}$

Kwaliteitsborging

Literatuur

Verantwoording

49

Bijlage 1 Enquêtevragen

50

Bijlage 2 Etappes

Bijlage 3 Motivaties

55 


\section{Samenvatting}

Betrokken burgers leveren een belangrijke bijdrage aan de ontwikkeling, behoud en bescherming van natuur en biodiversiteit. We weten echter nog weinig over de voorwaarden waaronder burgerbetrokkenheid leidt tot substantiële resultaten en systeemveranderingen, bijvoorbeeld in het beleid. In het Kennisbasis-project 'Citizens for Biodiversity' onderzoekt Wageningen Research hoe initiatieven of activiteiten van burgers een bijdrage leveren aan veranderingen in het natuurbeleid. Een van de casussen in dit project is 'burgerbetrokkenheid bij het voorkomen van plastic soep in zeeën en oceanen'.

Een enquête onder de deelnemers van de landelijke Boskalis Beach Clean-up Tour, die sinds 2013 jaarlijks door Stichting De Noordzee wordt georganiseerd, levert belangrijke informatie voor het onderzoek naar de rol van burgerbetrokkenheid in het natuurbeheer. Stichting De Noordzee heeft de ruwe gegevens van de jaarlijkse enquête vertrouwelijk beschikbaar gesteld voor analyse voor dit onderzoek. Dit rapport beschrijft de resultaten van de analyse van de Beach Clean-up deelnemers enquête over de periode 2013-2019.

In het jaar 2019 zijn extra vragen voor het onderzoek naar de rol van burgerbetrokkenheid in het natuurbeheer opgenomen. Hieronder worden de conclusies weergegeven uit de analyse van de jaarlijkse enquête die Stichting De Noordzee heeft gehouden (2013-2019) en voor de additionele vragen (2019). Hierbij moet worden opgemerkt dat de enquêtes sterk verschillen per jaar, ook in de periode 2013-2018. De resultaten geven daarom niet altijd een representatief overzicht van de hele periode.

\section{Deelnemers enquête 2013-2019: Kenmerken en motivatie deelnemers}

De gemiddelde leeftijd van de deelnemers is ongeveer 50 jaar en de verdeling tussen mannen en vrouwen is ongeveer gelijk. E-mail, Facebook en LinkedIn waren de meest gebruikte media onder de deelnemers.

- De meeste deelnemers van de Beach Clean-up:

zijn ouder dan 40 jaar;

- bezoeken één tot enkele keren per jaar het Nederlandse strand aan de Noordzee;

hebben meestal natuur / dier(bescherming) als hobby;

zijn veelal thuis en/of in de vrije tijd ook bezig met het milieu;

zijn werkzaam in de sector Zorg en Gezondheid;

lezen een krant;

komen uit Noord- en Zuid-Holland;

zijn met de auto naar de Beach Clean-up gekomen;

hebben de reis speciaal voor de Beach Clean-up gemaakt;

hebben daar niet speciaal een vrije dag voor genomen;

hebben aangegeven volgend jaar weer mee te willen doen;

hebben plezier gehad;

hebben aangegeven dat ze denken dat de Beach Clean-up op de lange termijn

bijdraagt aan het verminderen van de plastic soep.

- De motivatie om deel te nemen:

- iets doen aan de plastic soep is in bijna alle jaren het meest genoemd als motivatie;

- deze motivatie heeft op basis van totaalaantal een stijgende trend over de periode 2013-2019, maar is relatief per respondent stabiel over de jaren;

- de motivatie voor een schoon strand en actie te ondernemen is relatief gezien (per respondent) wel sterk gestegen in de periode 2013 tot 2019;

- er is een stijgende trend in de verhouding natuur- versus mensgerichte (sportief/gezellig) motivatie. De natuur lijkt dus een steeds grotere rol te spelen voor mensen om in actie te komen. 


\section{Extra vragen onderzoek Burgerbetrokkenheid}

- Ongeveer 40\% van de deelnemers aan de Beach Clean-up in 2019 is naast deelname aan de Clean-up ook op andere manieren bij het milieu betrokken. Veelgenoemde vormen van betrokkenheid zijn hierbij:

- zwerfafval opruimen;

- afval scheiden;

- vegetarisch of biologisch eten;

- financieel steunen van goede doelen;

- vrijwilligerswerk;

- natuurvriendelijk tuinieren;

- lid van politieke partij.

- $\quad 75 \%$ van de deelnemers in 2019 geeft aan dat hun deelname aan de Clean-up de manier waarop ze dagelijks met zwerfafval omgaan heeft beïnvloed. Deelnemers zijn onder andere:

- zelf beter gaan opletten met recycling van plastic;

- minder plastic(artikelen) kopen;

○ in gesprek gaan met vrienden en familie over het plastic probleem;

- het opruimen van plastic op straat;

- mensen aanspreken wanneer afval op straat wordt gegooid.

- $\quad 74 \%$ van de deelnemers denkt dat hun deelname aan de Beach Clean-Up op de lange termijn bijdraagt aan het verminderen van de plastic soep.

\section{Aanbevelingen toekomstige enquête}

Om de enquêteresultaten op een eenvoudigere manier, met minder inspanning en met meer betrouwbaarheid beschikbaar te maken bevelen we aan om in de toekomst te werken met vaste basisvragen en een meerkeuzesysteem met vaste antwoord categorieën. 


\section{$1 \quad$ Introductie}

\subsection{Doel en kader}

Naast overheden en bedrijven leveren ook burgers een belangrijke bijdrage aan de ontwikkeling, behoud en bescherming van natuur en biodiversiteit. Betrokken burgers hebben aan de basis gestaan van de natuur- en milieubeweging in Nederland, en het succes van keurmerken zoals FSC (Forest Stewardship Council), MSC (Marine Stewardship Council) en Fair Trade is te danken aan politieke druk en veranderend aankoopgedrag van kritische consumenten. We weten echter nog weinig over de voorwaarden waaronder burgerbetrokkenheid leidt tot substantiële resultaten en systeemverandering.

In het Kennisbasis-project 'Citizens for biodiversity' ('De rol van burgers in het natuurbeheer') onderzoekt Wageningen Research hoe initiatieven of activiteiten van burgers een bijdrage leveren aan veranderingen in het natuurbeleid. In dit onderzoek staan twee casussen centraal (Kennisonline, 2019). De eerste casus onderzoekt burgerbetrokkenheid bij het voorkomen van plastic soep in zeeën en oceanen. Een belangrijke bron van informatie voor deze casus is de landelijke Boskalis Beach Clean-up Tour die sinds 2013 jaarlijks door Stichting De Noordzee wordt georganiseerd. De stichting houdt na afloop van iedere Beach Clea-up Tour een enquête onder de deelnemers, waarin onder andere wordt gevraagd naar motivaties om deel te nemen. Dit is belangrijke informatie voor het onderzoek naar de rol van burgerbetrokkenheid in het natuurbeheer. Stichting De Noordzee heeft de ruwe data van de enquêtes (geanonimiseerd) voor nadere analyse ter beschikking gesteld aan het onderzoeksteam van Wageningen Research. In dit rapport beschrijven we de resultaten van de analyse van de Beach Clean-up deelnemers enquête over de periode 2013-2019. Hierbij ligt de focus op de enquêtevragen die relevant zijn voor het onderzoek naar burgerbetrokkenheid. In 2019 heeft Stichting De Noordzee op verzoek van Wageningen Research extra vragen gericht op het Kennisbasisproject extra vragen opgenomen in de enquête.

\subsection{Onderzoeksvragen}

Om inzicht te verkrijgen in de bereidheid van burgers om maatschappelijke milieuproblemen aan te pakken willen we vooral een beeld krijgen van waarom mensen meedoen met de Beach Clean-up Tour (motivatie) en hoeveel moeite ze daar voor (willen) doen. Door gebruik te maken van de enquêtes proberen we antwoord te geven op de volgende vragen:

- Wat voor type mensen doen mee met de Beach clean-up?

- Wat is hun motivatie?
- Is de motivatie afhankelijk van/ beïnvloedt door media?
- Verandert de motivatie over de jaren?
- Volgend jaar weer meedoen?
- Bijdragen aan het op de lange termijn verminderen van de plasticsoep?
- Met plezier meegedaan?

- Aan welke etappe hebben ze mee gedaan? (Welk deel van het strand/ geografische ligging/ regio)

- Hoeveel moeite is gedaan om hieraan mee te doen?

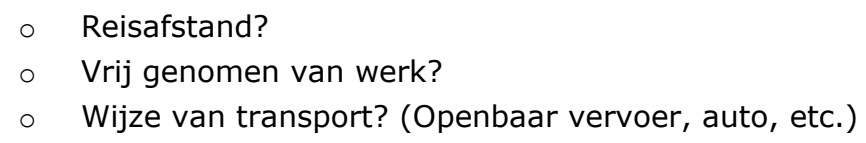




\section{Methode}

\subsection{Overzicht van alle gestelde vragen}

De ingevulde enquêtes van de Beach Clean-up Tour van de jaren 2013 t/m 2019 zijn door Stichting De Noordzee toegestuurd in de vorm van losse Excel-bestanden per jaar. Aangezien de enquête jaarlijks verschilt in zowel aantal als type vragen, is eerst een overzicht gemaakt van alle vragen die zijn gesteld (Bijlage 1 Enquêtevragen). Om vergelijking mogelijk te maken zijn de oorspronkelijke vragen iets aangepast tot een zoveel mogelijk uniforme vraagstelling. Aanpassingen zijn als volgt (indien relevant):

- Nummer van de vraag is verwijderd

- Jaartal is verwijderd

- Specificaties, die niet relevant zijn voor het onderzoek, zijn verwijderd zodat een generieke vraag ontstaat. Bijvoorbeeld de vraag "Wat vond je van de beschikbare materialen voor deelnemers?" is samengesteld uit de volgende originele enquêtevragen:

- 11. Wat vond je van de beschikbare materialen voor deelnemers? (Mueslireep)

- 10. Wat vond je van de beschikbare materialen voor deelnemers? (KRNWTR-bidons)

- 9. Wat vond je van de beschikbare materialen voor deelnemers? (Ansichtkaarten)

- 8. Wat vond je van de beschikbare materialen voor deelnemers? (Campagnekrant) Zo is het bijvoorbeeld ook mogelijk dat dezelfde vraag meerdere keren voorkomt in een jaar.

- Overige (kleine) tekstuele aanpassingen.

\subsection{Selectie relevante vragen}

Aangezien niet alle 64 vragen relevant zijn voor het onderzoek naar de rol van burgerbetrokkenheid in het natuurbeheer, is een selectie gemaakt. Daarvoor zijn de vragen eerst ingedeeld in 5 categorieën (Figuur 1):
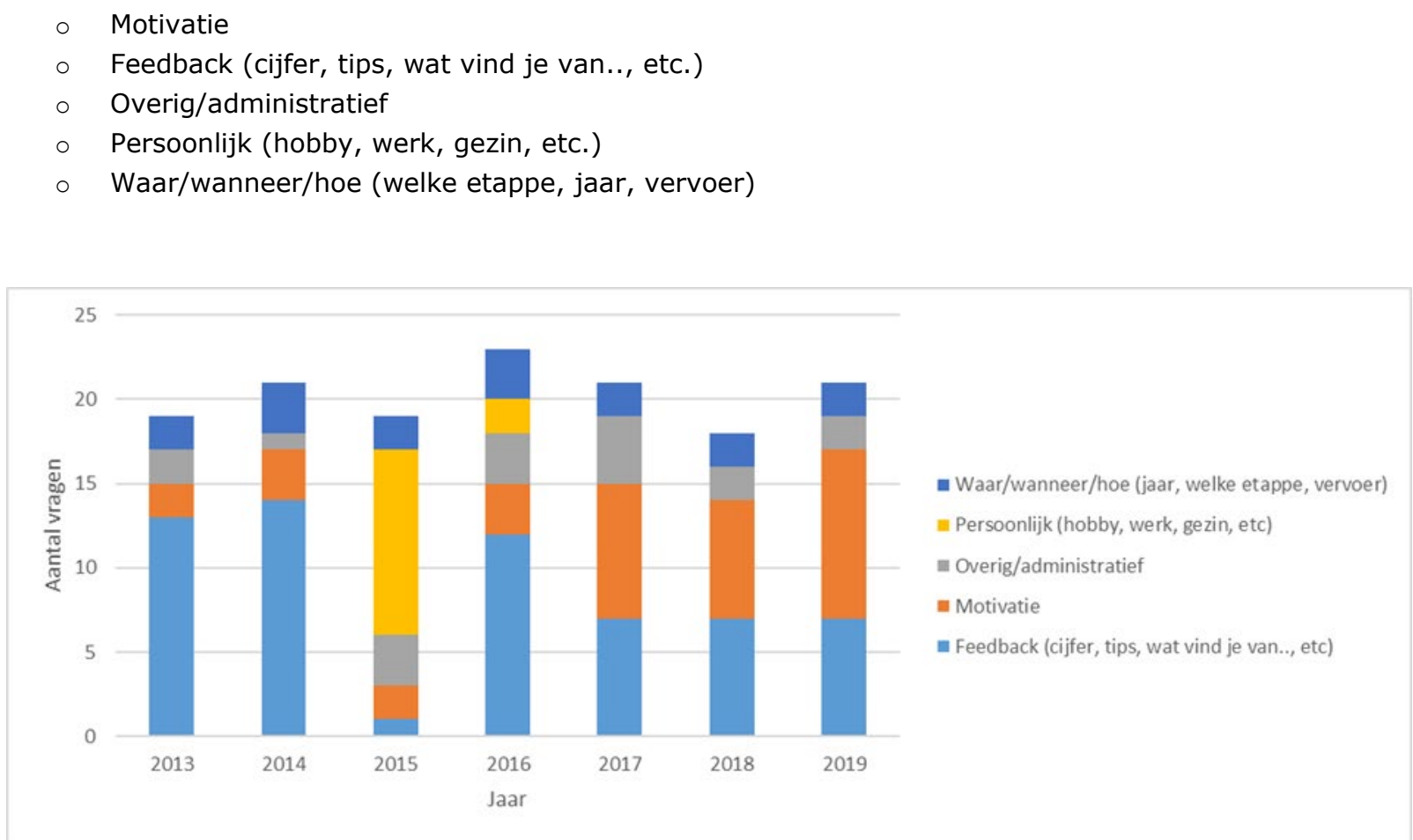

Figuur 1 Aantal vragen per categorie in de jaarlijkse enquête 
Per onderzoeksvraag is gekeken welke categorie enquêtevragen daar informatie over zou kunnen geven (Tabel 1). De potentieel interessante categorieën zijn motivatie, persoonlijk en waar/wanneer/hoe. De categorie 'overig/administratief' is niet relevant (dit gaat om vragen als naam, emailadres, wil je informatie ontvangen?, etc.). Ook de feedback categorie is niet relevant aangezien hier alle vragen zijn ondergebracht die gericht zijn op de organisatie (vragen als, hoe waren de snacks, wat vond je van de lengte van een etappe, de starttijd, etc.).

Tabel 1 Overzicht van de onderzoeksvragen waarbij is aangegeven welke categorie van de enquêtevragen daar mogelijk informatie over zou kunnen geven

\begin{tabular}{|c|c|}
\hline Onderzoeksvraag & Categorie enquêtevraag \\
\hline Wat voor type mensen doen mee met de Beach clean-up? & Persoonlijk \\
\hline \multicolumn{2}{|l|}{ Waarom doen ze mee? } \\
\hline Wat is hun motivatie? & Motivatie \\
\hline Is de motivatie afhankelijk van / beïnvloedt door media? & Motivatie \\
\hline Verandert de motivatie over de jaren? & Motivatie \\
\hline Volgend jaar weer meedoen? & Motivatie \\
\hline Bijdragen aan het op de lange termijn verminderen van de plasticsoep? & Motivatie \\
\hline $\begin{array}{l}\text { Aan welke etappe hebben ze mee gedaan? (Welk deel van het strand/ geografische } \\
\text { ligging/ regio) }\end{array}$ & Waar/wanneer/hoe \\
\hline \multicolumn{2}{|l|}{ Hoeveel moeite is gedaan om hieraan mee te doen? } \\
\hline Reisafstand? & Waar/wanneer/hoe \\
\hline Vrij genomen van werk? & Motivatie \\
\hline Wijze van transport? (Openbaar vervoer, georganiseerde reis, etc.) & Waar/wanneer/hoe \\
\hline \multicolumn{2}{|l|}{ Wat krijgen ze ervoor terug/denken ze ermee te bereiken? } \\
\hline Met plezier meegedaan? & Motivatie \\
\hline Volgend jaar weer meedoen? & Motivatie \\
\hline Bijdragen aan het op de lange termijn verminderen van de plasticsoep? & Motivatie \\
\hline
\end{tabular}

Voor de uiteindelijke selectie van vragen is gebruik gemaakt van de categorieën, maar is ook nog gekeken naar de individuele vragen. In totaal zijn er 27 vragen meegenomen in de analyse (Tabel 2) en zijn er 29 van de 64 vragen als niet relevant beoordeeld (Bijlage 1 Enquêtevragen). De overige 8 vragen zijn mogelijk interessant en kunnen eventueel in een later stadium worden meegenomen.

In 2019 zijn er voor het onderzoek naar burgerbetrokkenheid extra vragen opgenomen (zie 2.4). Een van deze vragen was of de deelnemer toestemming geeft dat de informatie die wordt gegeven ook door anderen dan Stichting De Noordzee mogen worden gebruikt voor analyse en onderzoek. Alle respondenten die daar nee op hebben geantwoord zijn uit de analyse voor het jaar 2019 gehaald. Dit ging om 47 van de in totaal 338 respondenten.

Voor elk jaar zijn van de enquêtes de relevante vragen geselecteerd en in een Excel sheet gekopieerd, met daarbij vermelding van het jaar en een uniek ID (jaar_volgnummer) om de originele volgorde van de respondenten te kunnen blijven behouden. Elke rij staat voor een respondent in een bepaald jaar en in kolommen staan de vragen.

Tabel 2 Overzicht van de enquêtevragen over de Beach clean-up tour 2013 t/m 2019 die zijn meegenomen in de analyse, ingedeeld per categorie. Om vergelijking mogelijk te maken zijn de oorspronkelijke vragen iets aangepast tot een uniforme opzet.

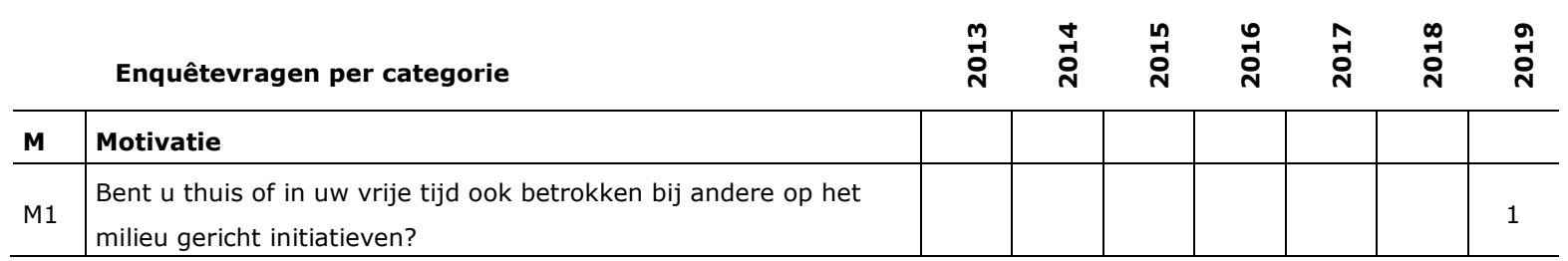




\begin{tabular}{|c|c|c|c|c|c|c|c|c|}
\hline M2 & $\begin{array}{l}\text { Denkt u dat uw meehelpen aan de Beach Clean-up Tour bijdraagt } \\
\text { aan het op de lange termijn verminderen van de plasticsoep? }\end{array}$ & & & & & & & 1 \\
\hline M3 & $\begin{array}{l}\text { Heb je een dag vrij genomen om deel te nemen aan dit } \\
\text { evenement? }\end{array}$ & & & & & 1 & 1 & 1 \\
\hline M4 & $\begin{array}{l}\text { Heeft het weer invloed op jouw deelname? Zou je ook het strand } \\
\text { willen schoonmaken bij slecht(er) weer? }\end{array}$ & & & & & 1 & & \\
\hline M5 & $\begin{array}{l}\text { Hoe groot is de kans dat je Boskalis Beach Clean-up Tour } \\
\text { aanbeveelt bij vrienden, familie en/of collega's? }\end{array}$ & & & 1 & & & & \\
\hline M6 & $\begin{array}{l}\text { Wat is jouw belangrijkste motivatie geweest om met een etappe } \\
\text { mee te helpen? }\end{array}$ & 1 & 1 & 1 & 1 & 1 & 1 & 1 \\
\hline M7 & Wil je volgend jaar weer meedoen? & & & & & 1 & 1 & 1 \\
\hline M8 & Zou je de Beach Clean-up Tour aanraden aan anderen? & & & & & 1 & 1 & 1 \\
\hline M9 & $\begin{array}{l}\text { Zou je ook meedoen als we de Beach Clean-up Tour in een ander } \\
\text { seizoen zouden organiseren? }\end{array}$ & & & & & 1 & 1 & 1 \\
\hline $\mathbf{P}$ & Persoonlijk (hobby, werk, gezin, etc.) & & & & & & & \\
\hline P1 & $\begin{array}{l}\text { Hoe vaak bezoek je gemiddeld het Nederlandse strand aan de } \\
\text { Noordzee? }\end{array}$ & & & 1 & & & & \\
\hline P2 & $\begin{array}{l}\text { In welke categorie valt jouw hobby? (Meerdere antwoorden } \\
\text { mogelijk) }\end{array}$ & & & 1 & & & & \\
\hline P3 & $\begin{array}{l}\text { In welke sector ben je werkzaam? (Meerdere antwoorden } \\
\text { mogelijk) }\end{array}$ & & & 1 & & & & \\
\hline P4 & Lees je een krant? Zo ja welke: (Meerdere antwoorden mogelijk) & & & 1 & & & & \\
\hline P5 & $\begin{array}{l}\text { Van welke (social) media maak je gebruik? (Meerdere antwoorden } \\
\text { mogelijk) }\end{array}$ & & & 1 & & & & \\
\hline P6 & Wat is je geboortedatum? & & & 1 & & & & \\
\hline P7 & Wat is je geslacht? & & & 1 & & & & \\
\hline P8 & Wat is je gezinssituatie? (Meerdere antwoorden mogelijk) & & & 1 & & & & \\
\hline P9 & Wat is je leeftijd? & & & & 1 & & & \\
\hline P10 & Wat is je woonplaats? & & & 1 & 1 & & & \\
\hline P11 & $\begin{array}{l}\text { Wat voor opleiding(en) heb je gevolgd? (Meerdere antwoorden } \\
\text { mogelijk) }\end{array}$ & & & 1 & & & & \\
\hline P12 & Welk(e) strand(en) en strandpaviljoen(s) bezoek je het meeste? & & & 1 & & & & \\
\hline $\mathbf{w}$ & Waar/wanneer/hoe (jaar, welke etappe, vervoer) & & & & & & & \\
\hline W1 & Heb je de hele etappe of een gedeelte meegelopen? & 1 & 1 & & 1 & & & \\
\hline W2 & Hoeveel etappes heb je in totaal meegelopen? & & & 1 & & & & \\
\hline W3 & $\begin{array}{l}\text { In welk jaar heb je meegedaan aan de Beach Clean-up Tour? } \\
\text { (Meerdere antwoorden mogelijk) }\end{array}$ & & & 1 & & & & \\
\hline W4 & Met welk vervoersmiddel ben je naar de etappe gekomen? & & 1 & & 1 & & & \\
\hline W5 & Was je tijdens jouw etappe van de Beach Clean-up: & & & & & 1 & 1 & 1 \\
\hline \multirow[t]{2}{*}{ W6 } & Welke etappe(s) heb je gelopen? & 1 & 1 & & 1 & 1 & 1 & 1 \\
\hline & Totaal & 3 & 4 & 15 & 6 & 8 & 7 & 9 \\
\hline
\end{tabular}

\subsection{Harmoniseren van antwoorden}

Voor de selectie van vragen is vervolgens is getracht zoveel mogelijk uniformiteit te verkrijgen in de antwoorden op een vraag. Per categorie is hieronder aangegeven welke aanpassingen zijn gedaan. 


\subsubsection{Persoonlijk}

Voor de categorie persoonlijk zijn 12 vragen geselecteerd (Tabel 3), waarvan bijna alle vragen in 2015 zijn gesteld. Eventuele aanpassingen aan de antwoorden staan onder de tabel aangegeven.

Tabel 3 Overzicht van de geselecteerde enquêtevragen over de Beach clean-up tour 2013 t/m 2019 in de categorie persoonlijk.

\begin{tabular}{l|l|l|l|l|l|l|l}
\hline \\
Enquêtevragen
\end{tabular}

$\underline{P 1 .}$ Hoe vaak bezoek je gemiddeld het Nederlandse strand aan de Noordzee?

De antwoorden zijn vrij gestructureerd en er is geen aanpassing nodig.

P2. In welke categorie valt jouw hobby? (Meerdere antwoorden mogelijk)

Alle antwoorden waarbij meerdere hobby categorieën zijn aangegeven zijn opgesplitst in meerdere kolommen zodat er maar één categorie per kolom staat aangegeven. Het maximum aan genoemde hobby categorieën per respondent is 10 . Deze staan genoemd in de kolommen 'Hobby_1' $t / m$ 'Hobby_10'.

P3. In welke sector ben je werkzaam? (Meerdere antwoorden mogelijk)

Alle antwoorden waarbij meerdere sectoren zijn aangegeven zijn opgesplitst in meerdere kolommen zodat er maar één sector per kolom staat aangegeven. Het maximum aan genoemde sectoren per respondent is 3. Deze staan genoemd in de kolommen 'Werk_1' $t / m$ 'Werk_3'. De genoemde sectoren zijn in sommige gevallen iets aangepast om zoveel mogelijk uniformiteit te verkrijgen.

\section{P4. Lees je een krant? Zo ja welke: (Meerdere antwoorden mogelijk)}

Antwoorden zijn aangepast in 'ja' en 'nee', zonder vermelding van welke krant. Er worden er namelijk veel genoemd en de bijdrage daarvan aan dit onderzoek is minimaal.

\section{P5. Van welke (social) media maak je gebruik? (Meerdere antwoorden mogelijk)}

Meerdere antwoorden (Mail, Facebook, LinkedIn, Instagram, etc.) zijn opgesplitst in afzonderlijke kolommen. Het maximum aan genoemde media per respondent is 6 . Deze staan genoemd in de kolommen 'Media_1' t/m 'Media_6'. 


\section{P6. Wat is je geboortedatum?}

Deze vraag kan gebruikt worden om de leeftijd van de deelnemers te achterhalen. De leeftijd wordt in een extra kolom gezet ("P6. Leeftijd"). Op basis daarvan wordt de leeftijd ingedeeld in categorieën, om aan te sluiten bij het antwoord op de vraag 'Wat is je leeftijd?' (Zie P9 hieronder). In een extra kolom gezet 'P6. Leeftijd categorie'.

\section{P7. Wat is je geslacht?}

Geen aanpassing nodig.

P8. Wat is je gezinssituatie? (Meerdere antwoorden mogelijk)

Vanwege de combinatie van antwoorden is deze vraag opgesplitst in 2 afzonderlijke vragen: 1) Partner of alleenstaand? Antwoord: 'Partner' 'Alleenstaand' of 'Onbekend'. De $2^{\text {de }}$ vraag is zijn er kinderen? Antwoord: 'Geen', 'Kinderen, jonger dan 12 jaar' , 'Kinderen, jonger en ouder dan 12 jaar', 'Kinderen, ouder dan 12 jaar' en 'Onbekend'.

P9. Wat is je leeftijd?

Antwoord in categorieën van telkens 10 jaar. Geen aanpassing nodig.

\section{P10. Wat is je woonplaats?}

De woonplaatsen geven weinig informatie omdat het te divers is en geen direct inzicht geeft in de ligging ten opzichte van de kust. Alle plaatsen afzonderlijk plotten en afstanden tot de kust berekenen is veel werk. Daarom zijn eerst de plaatsen ingedeeld per provincie, om daarmee inzichtelijk te krijgen of mensen in dezelfde regio (provincie) blijven voor deelname of dat er ook provincie overschrijdende deelnames zijn. Een extra kolom is toegevoegd om de provincie aan te geven ('P11 Provincie').

\section{P11. Wat voor opleiding(en) heb je gevolgd? (Meerdere antwoorden mogelijk)}

De antwoorden zijn bijna gelijk aan P3 (in welke sector ben je werkzaam). Deze vraag wordt daarom in dit stadium verder niet meegenomen.

\section{P12. Welk(e) strand(en) en strandpaviljoen(s) bezoek je het meeste?}

De antwoorden op deze vraag zijn heel divers en hebben veel combinaties. Het is tijdrovend om hier structuur in aan te brengen en de meerwaarde is niet heel groot. Deze vraag wordt daarom in dit stadium verder niet meegenomen.

\subsubsection{Motivatie}

Voor de categorie motivatie zijn 9 vragen geselecteerd (Tabel 4), waarvan er 5 meerdere jaren zijn gesteld. Eventuele aanpassingen aan de antwoorden staan onder de tabel aangegeven.

Tabel 4 Overzicht van de geselecteerde enquêtevragen over de Beach clean-up tour 2013 t/m 2019 in de categorie motivatie.

\begin{tabular}{|c|c|c|c|c|c|c|c|c|}
\hline \multicolumn{2}{|c|}{ Enquêtevragen } & \multirow[t]{2}{*}{$\stackrel{m}{\stackrel{m}{N}}$} & \multirow[t]{2}{*}{ 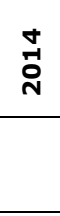 } & \multirow[t]{2}{*}{ 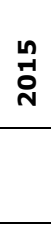 } & \multirow[t]{2}{*}{$\begin{array}{l}0 \\
0 \\
0 \\
\end{array}$} & \multirow[t]{2}{*}{$\hat{\circ}$} & \multirow[t]{2}{*}{$\stackrel{\infty}{\infty}$} & \multirow[t]{2}{*}{ ?ำ } \\
\hline M1 & $\begin{array}{l}\text { Bent } u \text { thuis of in uw vrije tijd ook betrokken bij andere } \\
\text { op het milieu gericht initiatieven? }\end{array}$ & & & & & & & \\
\hline M2 & $\begin{array}{l}\text { Denkt u dat uw meehelpen aan de Beach Clean-up Tour } \\
\text { bijdraagt aan het op de lange termijn verminderen van } \\
\text { de plasticsoep? }\end{array}$ & & & & & & & 1 \\
\hline M3 & $\begin{array}{l}\text { Heb je een dag vrij genomen om deel te nemen aan dit } \\
\text { evenement? }\end{array}$ & & & & & 1 & 1 & 1 \\
\hline M4 & $\begin{array}{l}\text { Heeft het weer invloed op jouw deelname? Zou je ook } \\
\text { het strand willen schoonmaken bij slecht(er) weer? }\end{array}$ & & & & & 1 & & \\
\hline M5 & $\begin{array}{l}\text { Hoe groot is de kans dat je Boskalis Beach Clean-up } \\
\text { Tour aanbeveelt bij vrienden, familie en/of collega's? }\end{array}$ & & & 1 & & & & \\
\hline
\end{tabular}




\begin{tabular}{|c|c|c|c|c|c|c|c|c|}
\hline \multicolumn{2}{|c|}{ Enquêtevragen } & $\stackrel{m}{\stackrel{m}{+}}$ & 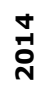 & Ln & $\underset{\substack{0\\
}}{\stackrel{N}{N}}$ & 今ે & $\stackrel{\infty}{\underset{1}{\infty}}$ & 穴 \\
\hline M6 & $\begin{array}{l}\text { Wat is jouw belangrijkste motivatie geweest om met een } \\
\text { etappe mee te helpen? }\end{array}$ & 1 & 1 & 1 & 1 & 1 & 1 & 1 \\
\hline M7 & Wil je volgend jaar weer meedoen? & & & & & 1 & 1 & 1 \\
\hline M8 & Zou je de Beach Clean-up Tour aanraden aan anderen? & & & & & 1 & 1 & 1 \\
\hline M9 & $\begin{array}{l}\text { Zou je ook meedoen als we de Beach Clean-up Tour in } \\
\text { een ander seizoen zouden organiseren? }\end{array}$ & & & & & 1 & 1 & 1 \\
\hline
\end{tabular}

M1. Bent u thuis of in uw vrije tijd ook betrokken bij andere op het milieu gericht initiatieven? Alle antwoorden ingedeeld in ja en nee (en blanco). Alle toelichting, met name waarbij men is betrokken, is per initiatief in aparte kolommen gezet. Het maximum aan genoemde initiatieven per respondent is 7 . Deze staan genoemd in de kolommen 'Milieu vrije tijd_1' $t / m$ 'Milieu vrije tijd_7'.

\section{M2. Denkt u dat uw meehelpen aan de Beach Clean-up Tour bijdraagt aan het op de lange termijn} verminderen van de plasticsoep?

Alle antwoorden ingedeeld in ja, weet niet en nee (en blanco). Met toelichting in (meerdere)

kolom(men) erbij gezet, getiteld 'Clean up draagt bij_1' $t / m$ 'Clean up draagt bij_4'.

\section{M3. Heb je een dag vrij genomen om deel te nemen aan dit evenement?}

Alleen antwoorden 'ja' en 'nee'. Geen aanpassing nodig.

M4. Heeft het weer invloed op jouw deelname? Zou je ook het strand willen schoonmaken bij slecht(er) weer?

Alleen antwoorden 'ja' en 'nee'. Geen aanpassing nodig.

M5. Hoe groot is de kans dat je Boskalis Beach Clean-up Tour aanbeveelt bij vrienden, familie en/of collega's?

Antwoorden zijn gegeven in de vorm van een score van 0 tot 10. Geen aanpassing nodig.

\section{M6. Wat is jouw belangrijkste motivatie geweest om met een etappe mee te helpen?}

De respondenten is gevraagd naar de motivatie om mee te doen aan de Beach Clean-up waarbij keuze kon worden gemaakt uit een aantal standaardantwoorden (die per jaar verschillend zijn) maar waarbij ook een vrij antwoord mogelijk was. Hierdoor zijn het aantal verschillende antwoorden groot. Om analyse mogelijk te maken zijn de motivaties onderverdeeld in categorieën, waarbij ook onderscheid gemaakt kan worden tussen motivatie vooral gericht op bijdragen aan natuur en milieu en motivatie vooral gericht op menselijke aspecten (Tabel 5). In Bijlage 1 en Bijlage 3 staan alle motivaties ingedeeld per categorie. Aangezien er meerdere motivaties per respondent mogelijk waren zijn eerst alle opgegeven motivaties (indien relevant) opgesplitst in afzonderlijke motivaties en in extra kolommen gezet. Het maximum aan genoemde motivaties per respondent is 8 . Deze staan genoemd in de kolommen 'Motivatie_1' $\mathrm{t} / \mathrm{m}$ 'Motivatie_8'.

\section{Tabel 5 Motivatie categorieën}

\begin{tabular}{l|c|c}
\hline \multicolumn{1}{c|}{ Categorie } & Natuur en milieu & Mens \\
\hline Bewustwording & $\mathrm{X}$ & \\
\hline Combinatie natuur/milieu en sportief/gezond/gezellig & $\mathrm{X}$ & $\mathrm{X}$ \\
\hline Educatief & $\mathrm{X}$ & $\mathrm{X}$ \\
\hline Goed doen (natuur, milieu, samenleving, St. de NZ) & $\mathrm{X}$ & \\
\hline Netwerken & & $\mathrm{X}$ \\
\hline Opruimen, schoon strand, actie ondernemen & $\mathrm{X}$ & \\
\hline Overig & & \\
\hline
\end{tabular}




\begin{tabular}{l|c|c}
\hline Categorie & Natuur en milieu & Mens \\
\hline Sportief, gezond en gezellig & & $\mathrm{X}$ \\
\hline Werk & & $\mathrm{X}$ \\
\hline
\end{tabular}

\section{M7. Wil je volgend jaar weer meedoen?}

Alle antwoorden zijn "ja", "nee", of "weet niet". Geen aanpassing nodig.

M8 Zou je de Beach Clean-up Tour aanraden aan anderen?

Alle antwoorden zijn "ja", "nee", of "weet niet". Geen aanpassing nodig.

M9. Zou je ook meedoen als we de Beach Clean-up Tour in een ander seizoen zouden organiseren? Op deze vraag was een vrij antwoord mogelijk en zijn het aantal verschillende antwoorden groot. Om analyse mogelijk te maken zijn de antwoorden onderverdeeld in categorieën: Nee (alleen zomer of niet meer mee willen doen); Ja, altijd (zonder restricties); Ja, behalve winter/slecht weer (uitgezonderd winter, vrieskou en/of slecht weer); Ja, mits in schoolvakantie/weekend; Ja, mits in schoolvakantie/weekend en goed weer; Misschien (andere redenaties). Andere redenaties dan seizoen/weersafhankelijk en vakantie/weekend zijn rekening houden met broedseizoen; de impact van zichtbaarheid bij strandgasten; en invloed van wind/storm op onderstuiven van afval.

Tabel 6 Indelen van antwoorden op vraag M9 (Zou je ook meedoen als we de Beach Clean-up Tour in een ander seizoen zouden organiseren?) in categorieën.

\begin{tabular}{|c|c|}
\hline Antwoorden op vraag M9 & Categorie \\
\hline Alle seizoenen mits het niet vriest :) & Ja, behalve winter/slecht weer \\
\hline Alleen in de schoolvakanties zuid & Ja, mits in schoolvakantie/weekend \\
\hline Als het bijvoorbeeld in vakantie of op zondag valt. & Ja, mits in schoolvakantie/weekend \\
\hline Als het boven de 12 graden is en in een schoolvakantie valt. & Ja, mits in schoolvakantie/weekend en goed weer \\
\hline Behalve winter & Ja, behalve winter/slecht weer \\
\hline \multicolumn{2}{|c|}{$\begin{array}{l}\text { Bij voorkeur niet in de zomer. Te warm. Maar ik realiseer me wel dat Ja } \\
\text { je dan minder aandacht krijgt. }\end{array}$} \\
\hline $\begin{array}{l}\text { Eind lente of begin herfst kan; maar zomer waarschijnlijk beste } \\
\text { weergarantie }\end{array}$ & Ja, behalve winter/slecht weer \\
\hline Het liefst met goed weer en niet te koud & Ja, behalve winter/slecht weer \\
\hline $\begin{array}{l}\text { Ik deed dit met jonge kleinkinderen (basisschool) en e.e.a. hangt } \\
\text { dus af van schoolvakanties en redelijk weer. }\end{array}$ & Ja, mits in schoolvakantie/weekend \\
\hline Ik denk alleen in de winter niet & Ja, behalve winter/slecht weer \\
\hline $\begin{array}{l}\text { Ik moet minimaal } 100 \mathrm{~km} \text { rijden naar het strand. Als het slecht weer } \\
\text { is; sneeuwt en/of veel file staat; is het voor mij geen optie. Dus } \\
\text { zomervakantie is meest geschikt; maar niet per se. }\end{array}$ & Ja, behalve winter/slecht weer \\
\hline Ik weet het niet. & Weet het niet \\
\hline Ik weet sowieso niet of ik nogmaals mee zou doen & Weet het niet \\
\hline Impact van zichtbaarheid is bij strandgasten nu wel groot & Misschien \\
\hline In lente en herfst & Ja, behalve winter/slecht weer \\
\hline$\underline{\mathrm{Ja}}$ & $\mathrm{ja}$ \\
\hline $\begin{array}{l}\text { Ja in alle seizoenen; maar in de winter moeten de etappes wel } \\
\text { korter zijn. De gelopen etappe was een goede afstand; langer was } \\
\text { niet prettig geweest }\end{array}$ & Ja \\
\hline Ja; in alle seizoenen & Ja \\
\hline Ja; in de herfst & Ja, behalve winter/slecht weer \\
\hline Ja; in de lente & Ja, behalve winter/slecht weer \\
\hline Ja; in de lente en de herfst & Ja, behalve winter/slecht weer \\
\hline $\begin{array}{l}\text { Ja; niet zozeer seizoensafhankelijk; meer agenda-gerelateerd (een } \\
\text { beetje weersverwachting ook; het moet wel te doen zijn) }\end{array}$ & Ja, behalve winter/slecht weer \\
\hline 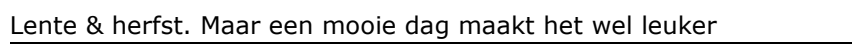 & Ja, behalve winter/slecht weer \\
\hline Lente en herfst & Ja, behalve winter/slecht weer \\
\hline
\end{tabular}




\begin{tabular}{|c|c|}
\hline Antwoorden op vraag M9 & Categorie \\
\hline Lente en zomer & Ja, behalve winter/slecht weer \\
\hline Lente of herfst & Ja, behalve winter/slecht weer \\
\hline Lente zomer en herfst & Ja, behalve winter/slecht weer \\
\hline Ligt eraan of het in een vakantie is & Ja, mits in schoolvakantie/weekend \\
\hline Maakt mij niet uit & Ja \\
\hline Maakt niet uit voor mij & $\mathrm{Ja}$ \\
\hline Nee; alleen de zomer & Nee \\
\hline $\begin{array}{l}\text { Nu was er m.i. de pech dat het gestormd had en dat we daardoor } \\
\text { veel afval gemist hebben; onder gestoven of de zee in!? }\end{array}$ & Misschien \\
\hline Ook in herfst en lente & Ja, behalve winter/slecht weer \\
\hline $\begin{array}{l}\text { Rekening houdend met broedseizoen zou het ook in een ander } \\
\text { seizoen kunnen. }\end{array}$ & Misschien \\
\hline Voor mij alleen te combineren met schoolvakanties & Ja, mits in schoolvakantie/weekend \\
\hline Voorjaar en herfst; winter niet zeker & Ja, behalve winter/slecht weer \\
\hline
\end{tabular}

Om na te gaan of de motivatie 'iets doen aan de plastic soep' toeneemt met de aandacht over plastic soep in het nieuws is gebruik gemaakt van de zoekmachine 'google'. Er is gezocht naar de zoektermen 'plastic soep soup' en de resultaten zijn per jaar gefilterd (2013-2019). Het aantal hits per jaar is gebruikt als representant voor de hoeveelheid aandacht in het nieuws.

\subsubsection{Waar/wanneer/hoe}

Voor de categorie waar/wanneer/hoe zijn 6 vragen geselecteerd (Tabel 7), waarvan er 4 meerdere jaren zijn gesteld. Eventuele aanpassingen aan de antwoorden staan onder de tabel aangegeven.

Tabel 7 Overzicht van de geselecteerde enquêtevragen over de Beach clean-up tour 2013 t/m 2019 in de categorie waar/wanneer/hoe.

\begin{tabular}{|c|c|c|c|c|c|c|c|c|}
\hline \multicolumn{2}{|c|}{ Enquêtevragen } & 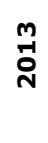 & $\stackrel{\text { N }}{\stackrel{4}{+}}$ & $\stackrel{\text { non }}{\text { no }}$ & $\stackrel{0}{0}$ & กั & $\stackrel{\infty}{\infty}$ & क्̀ \\
\hline W1 & Heb je de hele etappe of een gedeelte meegelopen? & 1 & 1 & & 1 & & & \\
\hline W2 & Hoeveel etappes heb je in totaal meegelopen? & & & 1 & & & & \\
\hline w3 & $\begin{array}{l}\text { In welk jaar heb je meegedaan aan de Beach Clean-up Tour? } \\
\text { (Meerdere antwoorden mogelijk) }\end{array}$ & & & 1 & & & & \\
\hline W4 & Met welk vervoersmiddel ben je naar de etappe gekomen? & & 1 & & 1 & & & \\
\hline W5 & Was je tijdens jouw etappe van de Beach Clean-up: & & & & & 1 & 1 & 1 \\
\hline W6 & Welke etappe(s) heb je gelopen? & 1 & 1 & & 1 & 1 & 1 & 1 \\
\hline
\end{tabular}

Per afzonderlijke vraag worden de aanpassingen genoemd:

W1 Heb je de hele etappe of een gedeelte meegelopen?

Er zijn verschillende antwoorden mogelijk. Deze antwoorden zijn iets aangepast om tot 2 verschillende antwoorden te komen: 


\begin{tabular}{l|l}
\hline Originele antwoord & Aangepaste antwoord \\
\hline De hele etappe & Hele etappe \\
\hline Deel van een etappe & Deel van een etappe \\
\hline Gedeelte & Deel van een etappe \\
\hline Hele etappe & Hele etappe \\
\hline Ongeveer 1 - 2 uur meegelopen & Deel van een etappe \\
\hline Ongeveer 2 - 3 uur meegelopen & Deel van een etappe \\
\hline Ongeveer 3 - 4 uur meegelopen & Deel van een etappe \\
\hline
\end{tabular}

\section{W2. Hoeveel etappes heb je in totaal meegelopen?}

Antwoord varieert van $1 \mathrm{t} / \mathrm{m} 5$ en meer dan 5 . Geen aanpassingen nodig.

W3. In welk jaar heb je meegedaan aan de Beach Clean-up Tour? (Meerdere antwoorden mogelijk) Deze vraag is relevant aangezien het aangeeft of iemand 1 of meerdere keren heeft meegedaan. Dit geeft inzicht in de motivatie aangezien meerdere keren meedoen een grotere motivatie aangeeft. Deze vraag wordt daarom aangepast tot: "hoeveel keer meegedaan?". De vraag is alleen in 2015 gesteld en het antwoord varieert daarom van 1 tot maximaal 3.

\section{W4. Met welk vervoersmiddel ben je naar de etappe gekomen?}

Geen aanpassing nodig.

\section{W5. Was je tijdens jouw etappe van de Beach Clean-up:}

Er zijn veel verschillende antwoorden gegeven, waarvoor harmonisatie nodig is. De volgende categorieën zijn gehanteerd (in de volgorde van weinig moeite tot veel moeite): in de buurt; gecombineerd (met vakantie, werk of familiebezoek); speciaal naar toe gereisd. Soms zijn er dubbele antwoorden gegeven, die elkaar zelfs kunnen tegenspreken. $\mathrm{Er}$ is dan een keuze gemaakt tussen de categorieën en geen extra kolommen toegevoegd om meerdere antwoorden mee te kunnen nemen.

De indeling is als volgt:

\begin{tabular}{|c|c|}
\hline Originele antwoord & Aangepaste antwoord \\
\hline Bij m'n moeder gelogeerd & Gecombineerd \\
\hline Familiebezoek op het eiland & Gecombineerd \\
\hline Favoriet strand & Gecombineerd \\
\hline $\begin{array}{l}\text { Ik werk bij Aloha en het was een mooi moment om voordat ik moest werken even mee te } \\
\text { helpen }\end{array}$ & Gecombineerd \\
\hline In het weekend hadden we de mogelijkheid er een dag voor uit te trekken. & Gecombineerd \\
\hline Op vakantie? & Gecombineerd \\
\hline Op vakantie?;Speciaal naar toe gereisd & Speciaal naar toe gereisd \\
\hline Op vakantie?;Speciaal naartoe gereisd & Speciaal naar toe gereisd \\
\hline Op vakantie?;Speciaal naartoe gereisd; Met jouw bedrijf/organisatie mee & Speciaal naar toe gereisd \\
\hline Op vakantie?; Woon je in de buurt & Speciaal naar toe gereisd \\
\hline Pension & Speciaal naar toe gereisd \\
\hline Speciaal naar toe gereisd & Speciaal naar toe gereisd \\
\hline Speciaal naar toe gereisd; Ik ben in Monster geboren & Speciaal naar toe gereisd \\
\hline
\end{tabular}




\begin{tabular}{|c|c|}
\hline Originele antwoord & Aangepaste antwoord \\
\hline Speciaal naartoe gereisd; bij familie in de buurt verbleven voor/na & Speciaal naar toe gereisd \\
\hline Speciaal naartoe gereisd; Ik heb 15 dagen vrijgehouden om mee te kunnen doen & Speciaal naar toe gereisd \\
\hline Speciaal naartoe gereisd; Met jouw bedrijf/organisatie mee & Speciaal naar toe gereisd \\
\hline Vanwege de storm afgemeld......... & Niet gegaan \\
\hline Verblijf op jaarplaats op het eiland & Gecombineerd \\
\hline Vrijwillig gepensioneerd & Gecombineerd \\
\hline $\begin{array}{l}\text { Vrijwilligersverlof. Van mijn werkgever ABN-AMRO mag ik } 36 \text { uur vrijwilligerswerk doen } \\
\text { tijdens werktijd. }\end{array}$ & Gecombineerd \\
\hline Wij mogen eigen vrijwilligersdagen inplannen vanuit werk & Gecombineerd \\
\hline Woon in Noord-Holland; en het was weekend & In de buurt \\
\hline Woon je in de buurt & In de buurt \\
\hline Woon je in de buurt; en samen met de nieuwe IVN gidsen & In de buurt \\
\hline Woon je in de buurt; Ik mag van mijn baas 3 dagen per jaar inzetten voor een goed doel. & Gecombineerd \\
\hline Woon je in de buurt; Met jouw bedrijf/organisatie mee & Gecombineerd \\
\hline Woon je in de buurt; Speciaal naar toe gereisd & In de buurt \\
\hline Woon je in de buurt; Speciaal naartoe gereisd & In de buurt \\
\hline
\end{tabular}

\section{W6. Welke etappe(s) heb je gelopen?}

De vraag over welke etappe is gelopen is elk jaar gesteld, met uitzondering van 2015. Om de reisafstand te kunnen bepalen is het nodig om van de deelnemers zowel de woonplaats als de etappe te weten. De woonplaats is gevraagd in 2015 en 2016 (zie vraag P10). Dat betekent dat de reisafstand maar voor één van de zes clean-up tours bepaald kan worden, namelijk in 2016. Voor dat jaar is de reisafstand geschat door gebruik te maken van de site www.afstand-berekenen.nl, waarbij voor het vertrekpunt de ingevulde woonplaats is ingevoerd en het eindpunt de bijbehorende plaats van eerst genoemde etappe. Voor de plaats per etappe zie Bijlage 2. De vraag of de deelnemer speciaal voor de gelegenheid is gaan reizen of dat de reis is gecombineerd met vakantie, familiebezoek, etc. is niet gesteld in 2016.

De vraag naar de etappes is per jaar heel verschillend beantwoord. Dit is mede omdat de etappes zijn veranderd in de loop der tijd (Figuur 2 en Figuur 3). 


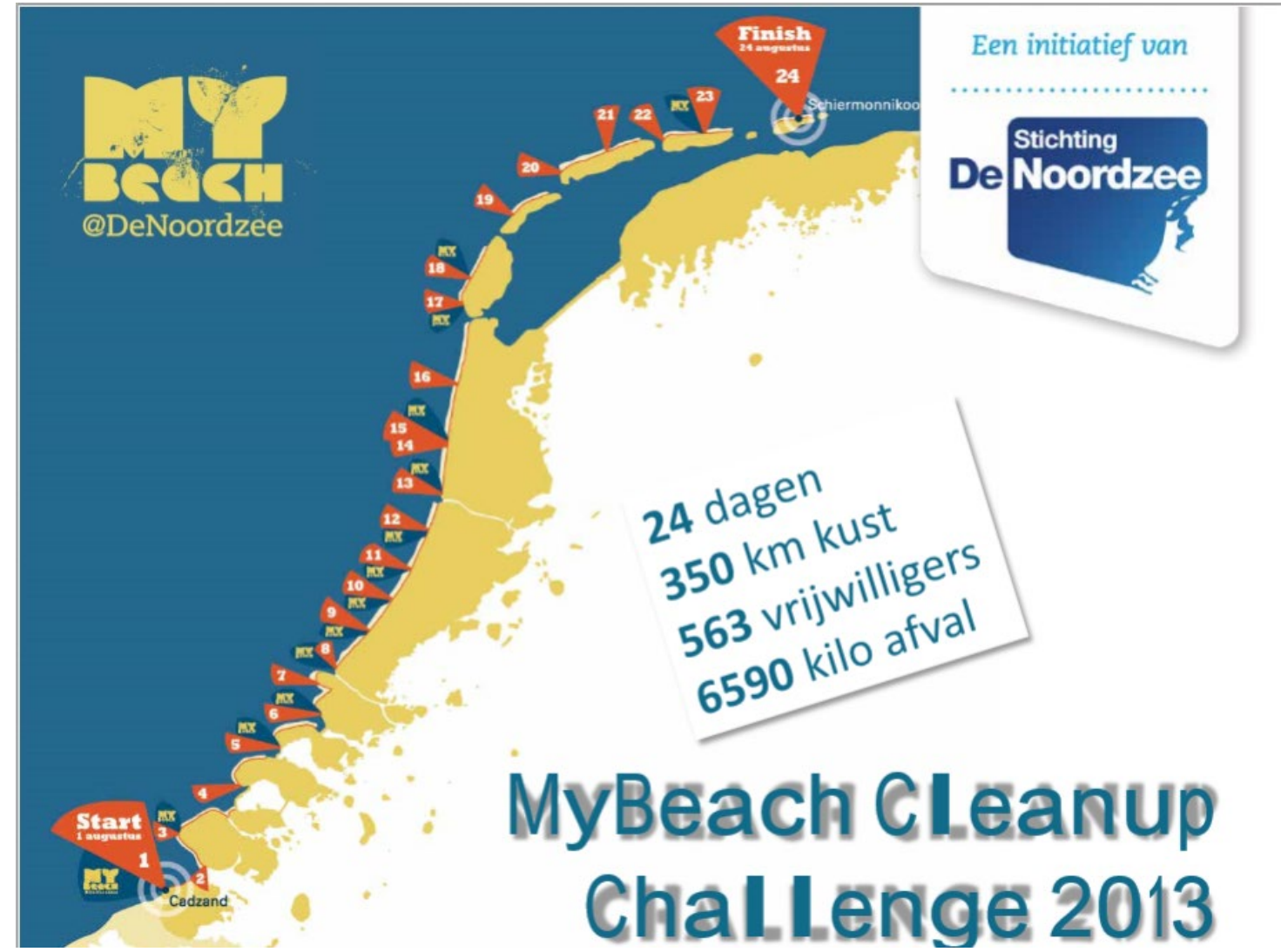

Figuur 2 Etappes van de Beach clean-up in de periode 2013-2016. Start vanuit het meest zuidelijke (Cadzand) en finish in het meest noordelijke punt (Schiermonnikoog).

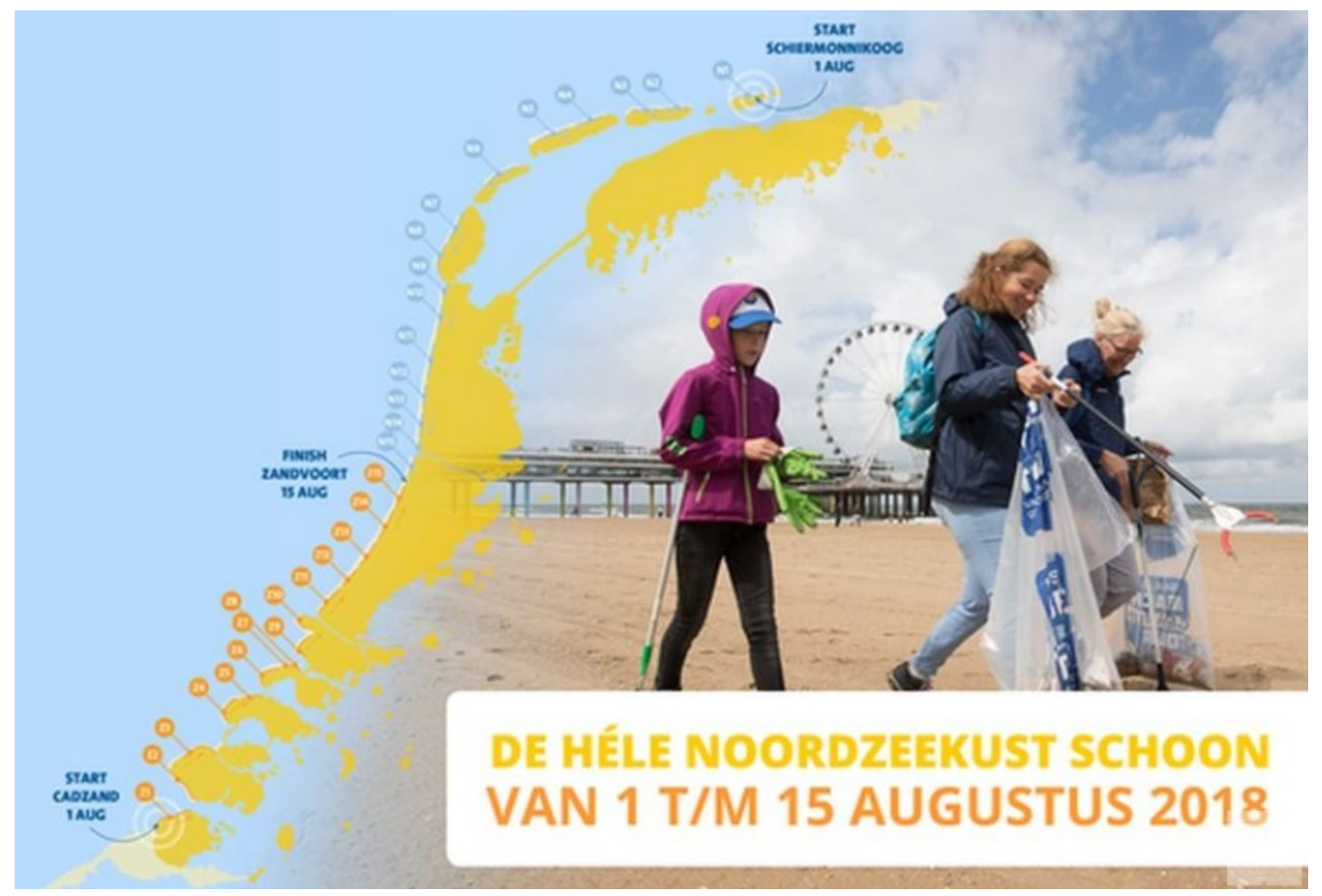

Figuur 4 Etappes van de Beach clean-up in de periode 2017-2019. Start vanuit het meest zuidelijke (Cadzand) en meest noordelijke punt (Schiermonnikoog) met de finish in het midden (Zandvoort).

Gekozen is om de etappes van de eerste jaren aan te houden en de zuid en noord etappes aan te passen aan de etappes $1 \mathrm{t} / \mathrm{m} 31$ (Tabel 8). Meer informatie over de etappes is gegeven in Bijlage 2 
Etappes. Indien meerdere etappes zijn gelopen zijn die in meerdere kolommen naast elkaar gezet. Het maximum gelopen etappes is 16 (Kolom 'Etappe_1' t/m 'Etappe_16').

Tabel 8 Zuid en noord etappes (2017-19) omzetten naar Etappes 1 t/m 31 (2013-16).

\begin{tabular}{|c|c|}
\hline Zuid en Noord etappes & Etappes 1 t/m 31 \\
\hline N1 & Etappe 31 \\
\hline N10 & Etappe 19 \\
\hline N11 & Etappe 19 \\
\hline N12 & Etappe 18 \\
\hline N13 & Etappe 17 \\
\hline N14 & Etappe 16 \\
\hline N15 & Etappe 15 \\
\hline N2 & Etappe 31 \\
\hline N3 & Etappe 29 \\
\hline N4 & Etappe 28 \\
\hline N5 & Etappe 26 \\
\hline N6 & Etappe 24 \\
\hline N7 & Etappe 23 \\
\hline N8 & Etappe 21 \\
\hline N9 & Etappe 20 \\
\hline $\mathrm{Z1}$ & Etappe 1 \\
\hline Z10 & Etappe 9 \\
\hline Z11 & Etappe 10 \\
\hline $\mathrm{Z} 12$ & Etappe 11 \\
\hline Z13 & Etappe 12 \\
\hline Z14 & Etappe 13 \\
\hline Z15 & Etappe 14 \\
\hline $\mathrm{Z2}$ & Etappe 2 \\
\hline Z3 & Etappe 3 \\
\hline Z4 & Etappe 4 \\
\hline $\mathrm{Z5}$ & Etappe 5 \\
\hline Z6 & Etappe 6 \\
\hline $\mathrm{Z7}$ & Etappe 6 \\
\hline Z8 & Etappe 7 \\
\hline$z 9$ & Etappe 8 \\
\hline
\end{tabular}

\subsection{Extra vragen burgerbetrokkenheidsonderzoek}

In overleg met Stichting De Noordzee zijn voor het project rond burgerbetrokkenheid in het natuurbeheer in 2019 vier extra vragen aan de deelnemers enquête toegevoegd (Tabel 9).

Tabel 9 Additionele vragen project burgerbetrokkenheid in de Beach Clean-up deelnemersenquete 2019.

\begin{tabular}{l|l}
\hline $\mathbf{N r}$. & Additionele vraag \\
\hline 16 & Bent u thuis of in uw vrije tijd ook betrokken bij andere op het milieu gericht initiatieven? \\
\hline 17 & $\begin{array}{l}\text { Hoe beïnvloedt uw deelname aan de Beach Clean-up Tour de manier waarop u in uw dagelijks leven omgaat met } \\
\text { zwerfafval? }\end{array}$ \\
\hline 18 & $\begin{array}{l}\text { Denkt u dat uw meehelpen aan de Beach Clean-up Tour bijdraagt aan het op de lange termijn verminderen van de } \\
\text { plasticsoep? }\end{array}$ \\
\hline 20 & $\begin{array}{l}\text { Ik geef toestemming dat de gegevens van deze enquête ook gebruikt mogen worden door andere partijen dan } \\
\text { Stichting De Noordzee voor data-analyse en onderzoek. }\end{array}$ \\
\hline
\end{tabular}

In totaal gaven 47 van de 338 respondenten geen toestemming voor het gebruik van andere partijen dan Stichting De Noordzee voor analyse en onderzoek (Tabel 9, Nr.20). De antwoorden van deze 47 
respondenten zijn in de analyses van zowel de oorspronkelijke enquêtevragen van Stichting De Noordzee als de vragen voor het burgerbetrokkenheidproject niet meegenomen (zie 2.2).

\section{B1 Betrokkenheid bij milieu}

Bij vraag 16 kon er ja of nee geantwoord worden, sommige deelnemers geven een uitgebreid antwoord, op basis van dit antwoord is er gekozen om de deelnemer in categorie ja of nee te plaatsen voor de analyse.

Tabel 10 Voorbeelden van aangepaste antwoorden naast het origenele antwoord met betrekking tot de betrokkenheid bij het milieu van deelnemers aan de Beach Clean-Up in 2019

\begin{tabular}{|c|c|}
\hline Aangepast & Origineel \\
\hline $\mathrm{Ja}$ & $1 \times$ dit jaar met it fryske gea bij earnewoude opgeruimd. \\
\hline $\mathrm{Ja}$ & Financiële ondersteuning \\
\hline $\mathrm{Ja}$ & Tijdens NL Doet ruimen we als gemeenschap ons dorp op. \\
\hline Nee & Niet actief \\
\hline $\mathrm{Ja}$ & Zeehondenonderzoek waddenzee \\
\hline $\mathrm{Ja}$ & Ruim altijd troep op op straat \\
\hline $\mathrm{Ja}$ & Doe mijn best thuis bewust te kiezen en leven \\
\hline $\mathrm{Ja}$ & Als ik een mogelijkheid heb pak ik wat op \\
\hline $\mathrm{Ja}$ & Doe zelf veel aan afvalscheiding \\
\hline $\mathrm{Ja}$ & Zeehondenonderzoek waddenzee \\
\hline $\mathrm{Ja}$ & Ruim vrijwillig rommel op tijdens hond uitlaten \\
\hline $\mathrm{Ja}$ & raap 1x per maand afval \\
\hline $\mathrm{Ja}$ & $\begin{array}{l}\text { Ga vaak wandelen met een plastic zak voor afval dat ik } \\
\text { tegenkom. En ben sponsor van Ocean Cleanup. }\end{array}$ \\
\hline $\mathrm{Ja}$ & Regelmatig opruim wandelingen in mijn omgeving \\
\hline $\mathrm{Ja}$ & $\begin{array}{l}\text { Ik loop elke maandag in Hoek van Holland van de stena } \\
\text { line tot de waterkering langs de Nieuwe Waterweg. }\end{array}$ \\
\hline Nee & Niet officieel \\
\hline $\mathrm{Ja}$ & Doe vaker spontaan iets voor de natuur \\
\hline Ja & $\begin{array}{l}\text { Plastic verspilling tegen gaan bij horecabedrijf waar ik } \\
\text { werkzaam ben }\end{array}$ \\
\hline $\mathrm{Ja}$ & $\begin{array}{l}\text { We proberen zo bewust mogelijk te leven: alleen } \\
\text { biologische producten kopen }\end{array}$ \\
\hline $\mathrm{Ja}$ & Draag mijn steentje bij door geen vlees of vis te eten \\
\hline Nee & $\begin{array}{l}\text { Zou ik graag meer willen doen maar ik weet de weg niet } \\
\text { goed. }\end{array}$ \\
\hline $\mathrm{Ja}$ & $\begin{array}{l}\text { Tijdens hond uitlaten ruim ik altijd plastic en andere } \\
\text { dingen op }\end{array}$ \\
\hline $\mathrm{Ja}$ & Privé sorteer ik mijn afval \\
\hline $\mathrm{Ja}$ & $\begin{array}{l}\text { meer bij een plantenwerkgroep en ga mee met vogelaars } \\
\text { en geven dus zaken door aan waarnemingen. }\end{array}$ \\
\hline
\end{tabular}




\begin{tabular}{|l|l|}
\hline Aangepast & Origineel \\
\hline Ja & eigen initiatieven \\
\hline Nee & $\begin{array}{l}\text { Ik zorg dat ik altijd een afval zakje bij me heb. Waar ik } \\
\text { dan ook ben }\end{array}$ \\
\hline
\end{tabular}

\section{B2 Verandering van omgang met zwerfafval}

Bij de vraag met betrekking tot een verandering van de omgang met zwerfafval in het dagelijks leven werden onderstaande opties aangeboden:

- Wanneer mensen plastic op straat afgooien spreek ik hun daarop aan

- Opruimen zwerfafval op straat of in mijn omgeving dat ik vroeger zouden negeren

Helemaal niet

Gebruik/koop minder wegwerpplastic

- $\quad \mathrm{Ga}$ in gesprek met familie/vrienden over hoe wij kunnen allemaal zwerfafval reduceren/voorkomen

- Beter opletten met het recyclen van mijn eigen plastic/afval

Ook kon er een andere verandering/reden gegeven worden. In de analyse hebben wij deze andere redenen geschaard onder de categorie 'overig'.

Voorbeelden van overige antwoorden zijn:

- als moeder en juf geef ik het goede voorbeeld aan de toekomst.

- Ben al jaren een milieufreak. Eet al v a $17 \mathrm{jr}$ vegetarisch. Ben nu 68. Erg zuinig met materiaal en grondstoffen. Boodschappen doe ik zo veel mogelijk op de fiets.

- Gezamenlijk gevoel aandacht milieu.

- Het is andersom: door hoe ik dagelijks omga met zwerfafval ben ik gaan meedoen.

\section{B3 Bijdrage Clean-Up aan vermindering plastic soep}

Bij de vraag naar of deelnemers denken dat hun deelname bijdraagt aan de vermindering van plastic soep hebben we de antwoorden in vier categorieën gesorteerd: ja, nee, weet niet, misschien/hoop van wel.

Tabel 11 Voorbeelden van aangepaste antwoorden naast het origenele antwoord met betrekking tot de verwachte bijdrage van deelname aan de Beach Clean-Up (in 2019) aan het verminderen van de plastic soep.

\begin{tabular}{|c|c|}
\hline Aangepast & Origineel \\
\hline $\mathrm{Ja}$ & Alles helpt \\
\hline $\begin{array}{l}\text { Misschien/hoop } \\
\text { het }\end{array}$ & Als door deze acties mensen die afval laten slingeren hun gedrag veranderen \\
\hline Weet niet & Ben bang dat het veel \\
\hline $\mathrm{Ja}$ & Beperkt \\
\hline $\begin{array}{l}\text { Misschien/hoop } \\
\text { het }\end{array}$ & Dat is mijn hoop. \\
\hline $\begin{array}{l}\text { Misschien/hoop } \\
\text { het }\end{array}$ & Dat kan ik alleen maar hopen \\
\hline $\begin{array}{l}\text { Misschien/hoop } \\
\text { het }\end{array}$ & Dat zou mooi zijn \\
\hline Nee & De afval die we van het strand hebben gehaald is een druppel op een gloeiende plaat \\
\hline Nee & $\begin{array}{l}\text { Het volume van plastic soep is te groot. Er moet een project komen vanuit de overheid en grote } \\
\text { bedrijven }\end{array}$ \\
\hline
\end{tabular}




\section{Resultaten}

\subsection{Aantal respondenten}

Het aantal respondenten varieert van een minimum van 88 in 2013 tot een maximum van 361 in 2017 en laat een stijgende trend zien (Tabel 10, Figuur 4).

Tabel 10 Aantal respondenten per jaar.

\begin{tabular}{l|l}
\hline Jaar & Aantal respondenten \\
\hline 2013 & 88 \\
\hline 2014 & 200 \\
\hline 2015 & 260 \\
\hline 2016 & 160 \\
\hline 2017 & 361 \\
\hline 2018 & 213 \\
\hline 2019 & 338 \\
\hline
\end{tabular}

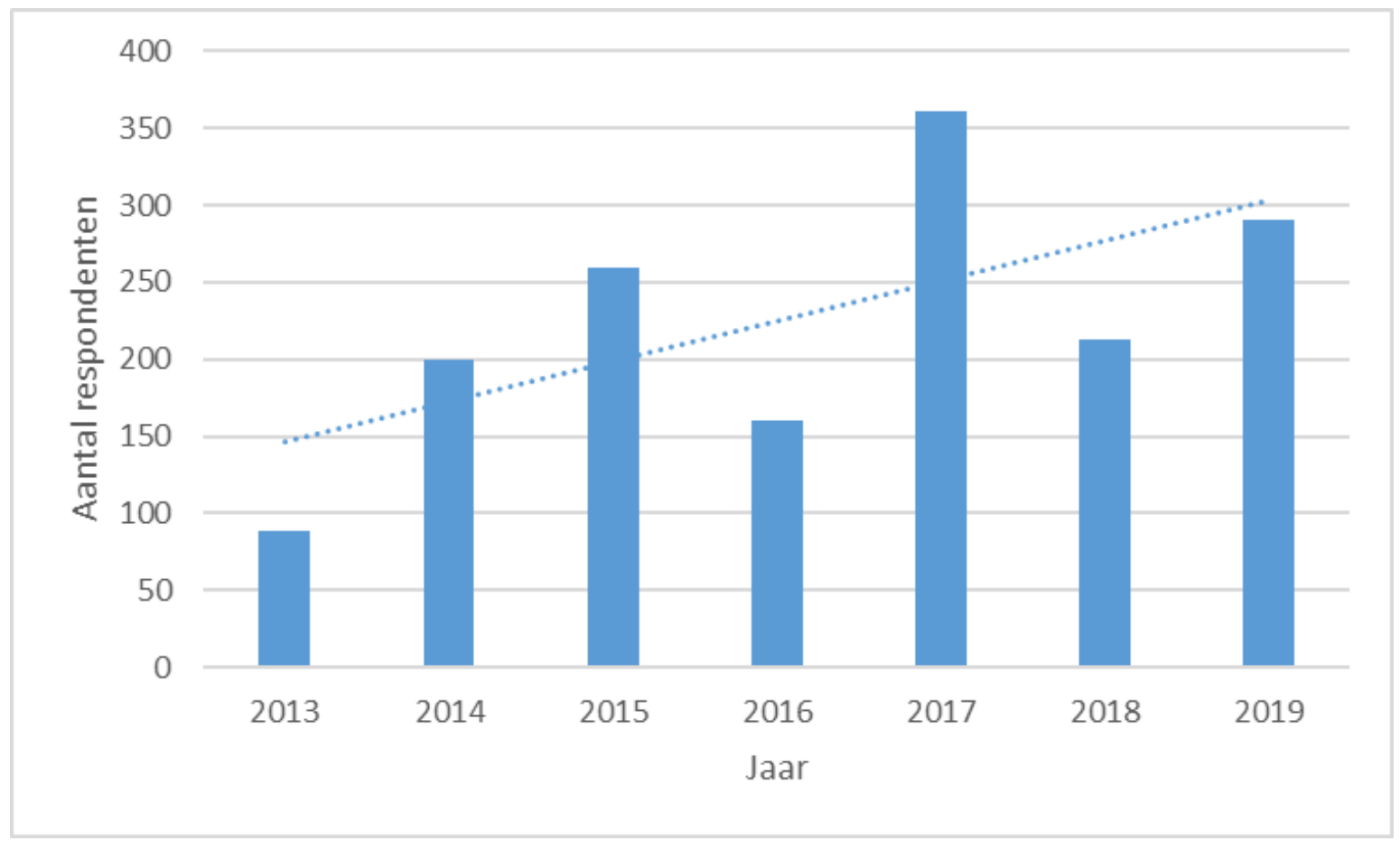

Figuur 5 Aantal respondenten per jaar.

\subsection{Persoonlijk}

Alle persoonlijke vragen om een indruk te krijgen van wat voor type mensen meedoen met de Beach clean-up zijn gesteld in 2015. Uitzondering hierop is de vraag 'Wat is je leeftijd?' die in 2016 is gesteld en 'Wat is je woonplaats?' die zowel in 2015 als in 2016 is gesteld. De resultaten geven dus geen representatief overzicht van de hele periode, maar slechts een moment opname. 


\subsubsection{Frequentie strandbezoek}

De meeste mensen bezoeken één tot enkele keren per jaar het Nederlandse strand aan de Noordzee (Figuur 5).

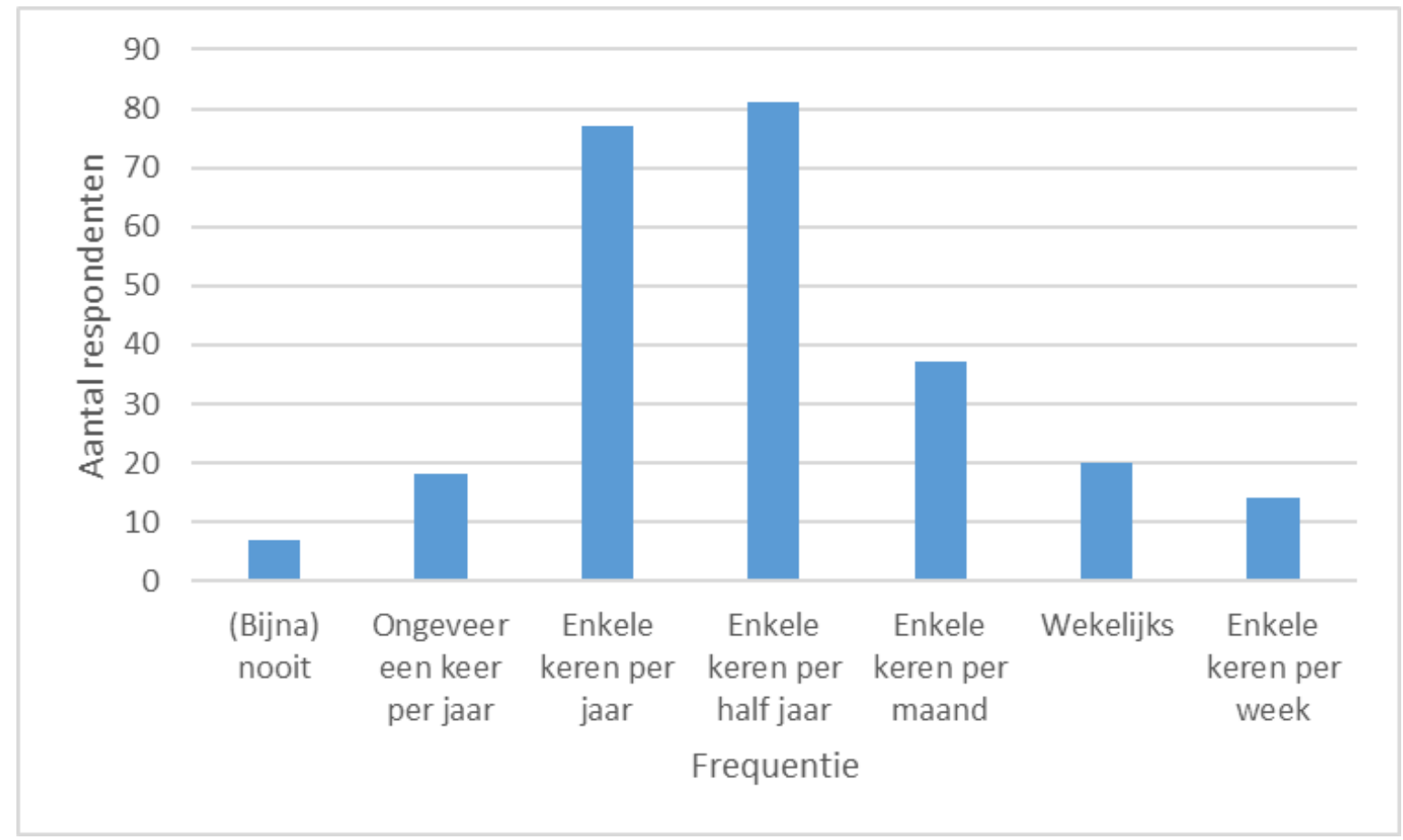

Figuur 6 Frequentie van bezoek aan Nederlandse strand aan de Noordzee, zoals aangegeven door deelnemers van de Beach Clean-up 2015.

\subsubsection{Hobby's en aandacht voor milieu}

Natuur / dier(bescherming) is het meest genoemd als hobby (Figuur 6). Andere populaire hobbycategorieën onder de respondenten zijn sport, literatuur/lezen, kunst/cultuur, muziek, koken/eten en yoga, meditatie, etc. $63 \%$ van de respondenten heeft aangegeven thuis of in zijn/haar vrije tijd ook betrokken te zijn bij andere op het milieu gericht initiatieven.

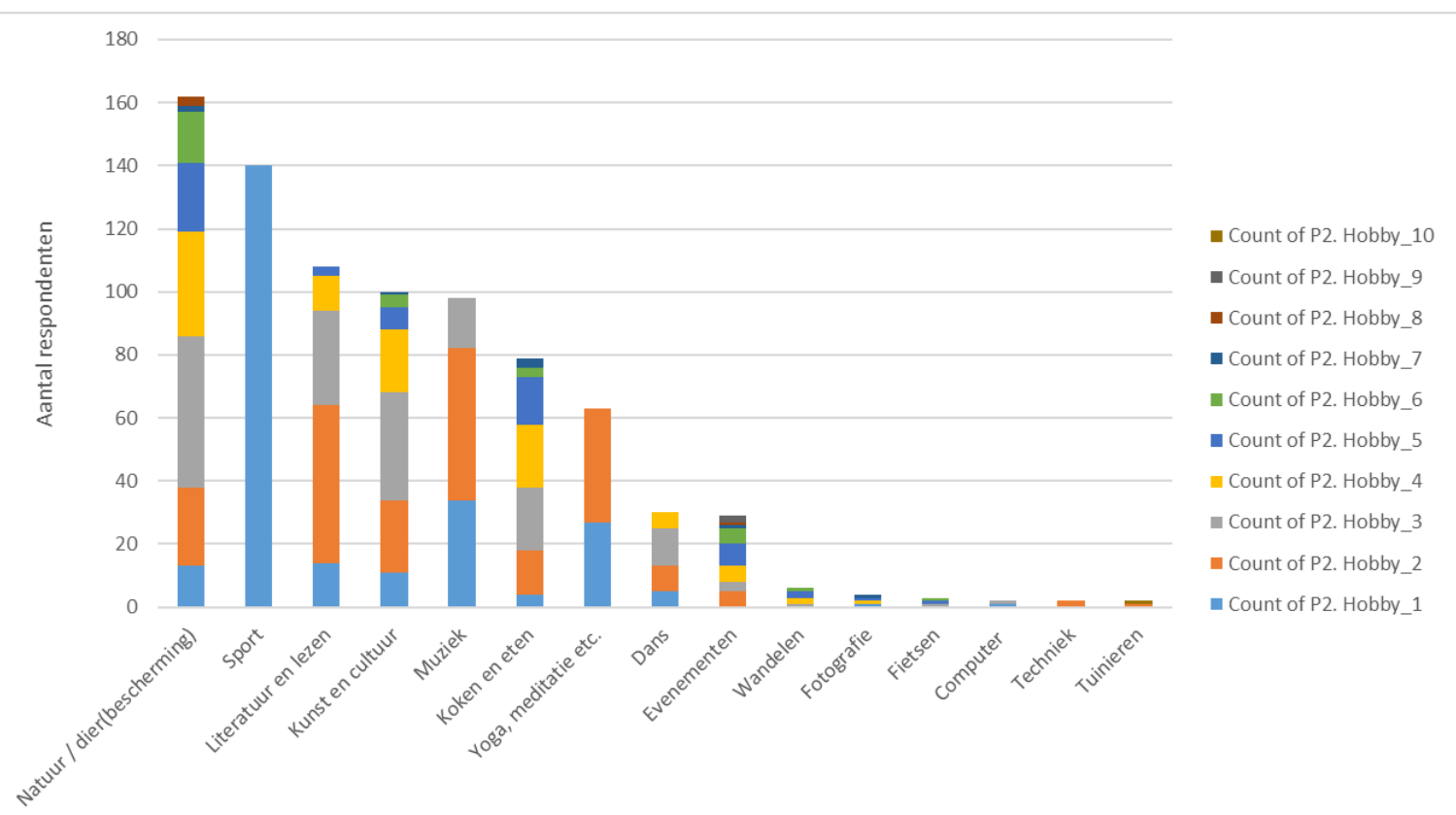

Figuur 7 Hobby's van deelnemers van de Beach Clean-up 2015, ingedeeld in categorieën. Hobby's die maar $1 x$ zijn genoemd en die niet in een categorie vallen zijn hier weggelaten. Er zijn meerdere antwoorden per respondent mogelijk. De kleuren geven de volgorde van antwoorden weer (maximum aantal antwoorden/hobby's was 10). 


\subsubsection{Werk en opleiding}

De top 5 sectoren waarin de deelnemers uit 2015 werkzaam waren zijn (Figuur 7):

1. Zorg en gezondheid;

2. Onderwijs en Opvoeding;

3. Economie en Bedrijf;

4. Aarde en milieu;

5. Techniek.

Deze 5 groepen omvatten ca. $48 \%$ van de deelnemers. Ongeveer $12 \%$ gaf aan niet werkzaam te zijn in een bepaalde sector (sector 'geen' in Figuur 7). Dit kan zijn omdat de respondent werkeloos is maar het kan ook zijn dat de respondent geen antwoord wilde geven. Ongeveer $10 \%$ van de deelnemers geeft aan gepensioneerd te zijn.

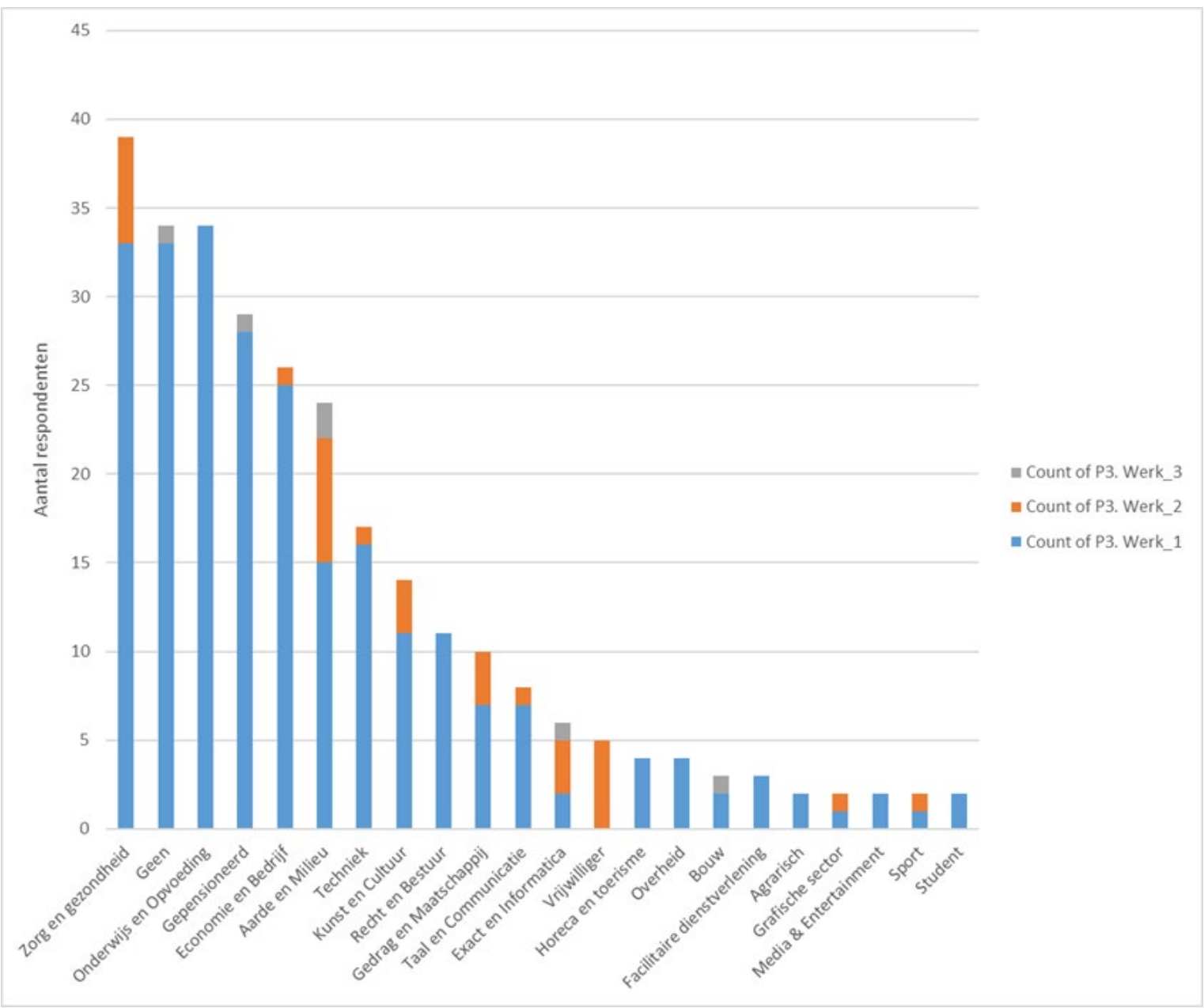

Figuur 8 Sector waarin de deelnemers van de Beach Clean-up 2015 werkzaam zijn, ingedeeld in categorieën. Sectoren die maar $1 x$ zijn genoemd en die niet in een categorie vallen zijn hier weggelaten. Er zijn meerdere antwoorden per respondent mogelijk. De kleuren geven de volgorde van antwoorden weer (maximum aantal antwoorden/sectoren was 3).

\subsubsection{Media}

Ruim driekwart van de respondenten in 2015 heeft aangegeven een krant te lezen (Figuur 8). Mail, Facebook en LinkedIn zijn in dit jaar de meest gebruikte media onder de deelnemers (Figuur 9). 


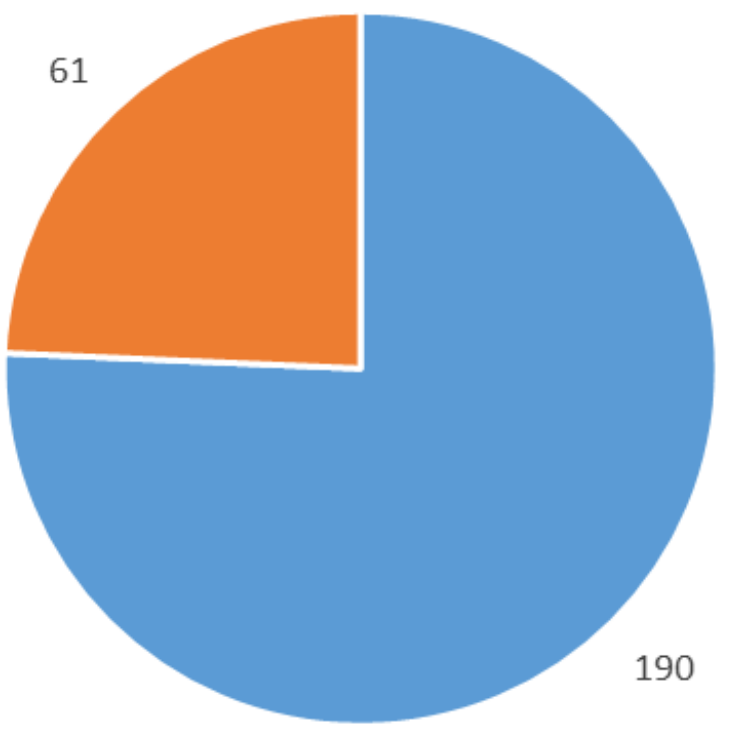

Figuur 9 Deelnemers van de Beach Clean-up 2015 die wel (ja) of geen (nee) krant lezen.

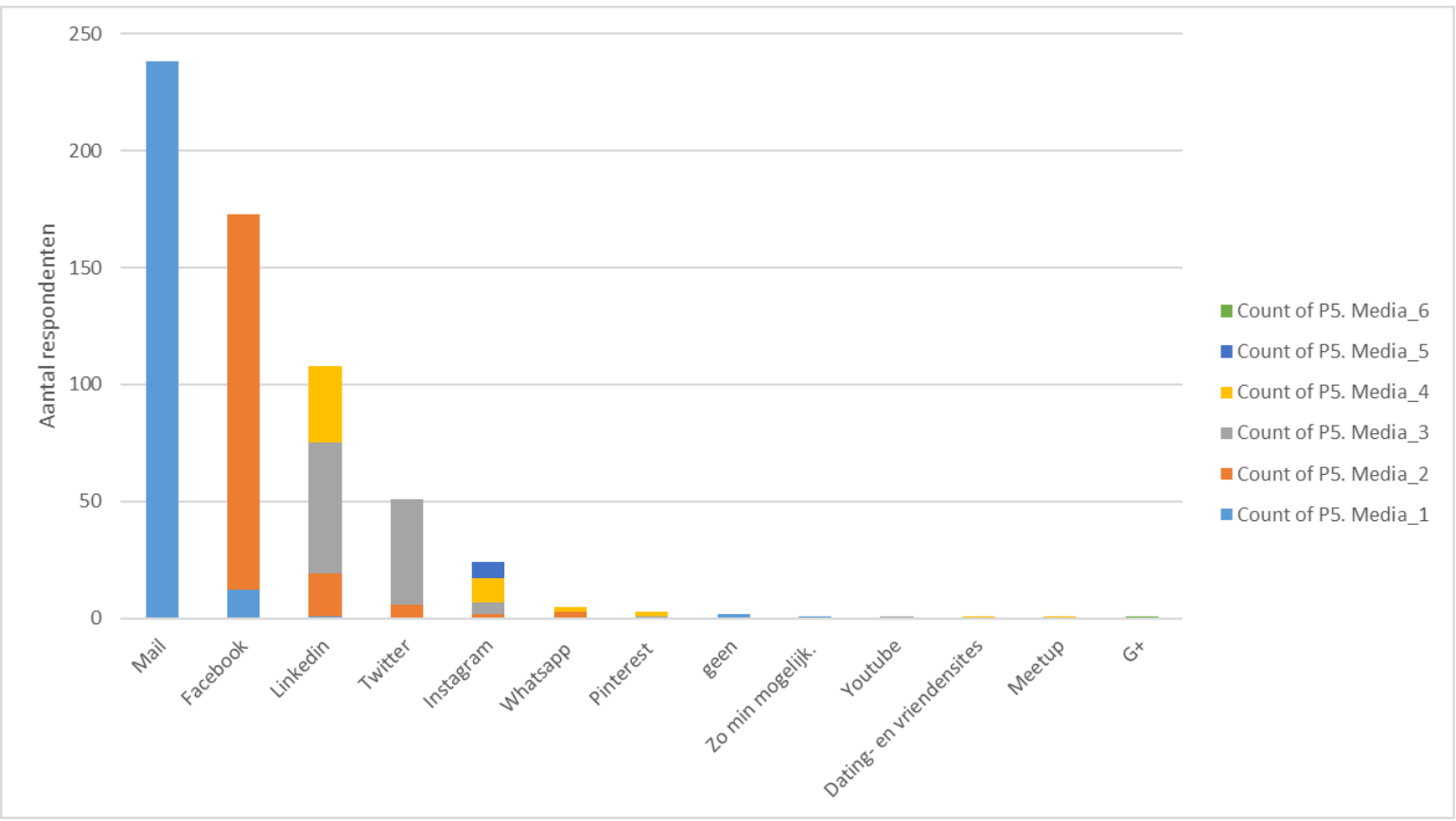

Figuur 10 Gebruik van (social) media onder de deelnemers van de Beach Clean-up 2015. Er zijn meerdere antwoorden per respondent mogelijk. De kleuren geven de volgorde van antwoorden weer (maximum aantal antwoorden/media was 6).

\subsubsection{Leeftijd, geslacht, gezinssituatie}

In 2015 is naar de geboortedatum van de respondenten gevraagd en in 2016 naar de leeftijdscategorie. De antwoorden van beide jaren geven inzicht in de leeftijd van de deelnemers (Figuur 10 en Figuur 11). De verdeling van de leeftijd is in 2015 en 2016 redelijk gelijk. Meer dan driekwart van de deelnemers zijn ouder dan 40 jaar. Op basis van de antwoorden uit 2015 blijkt de gemiddelde leeftijd van de deelnemers op ongeveer 50 jaar te liggen. Slechts 8 tot $9 \%$ van de deelnemers is jonger dan 30 jaar. 


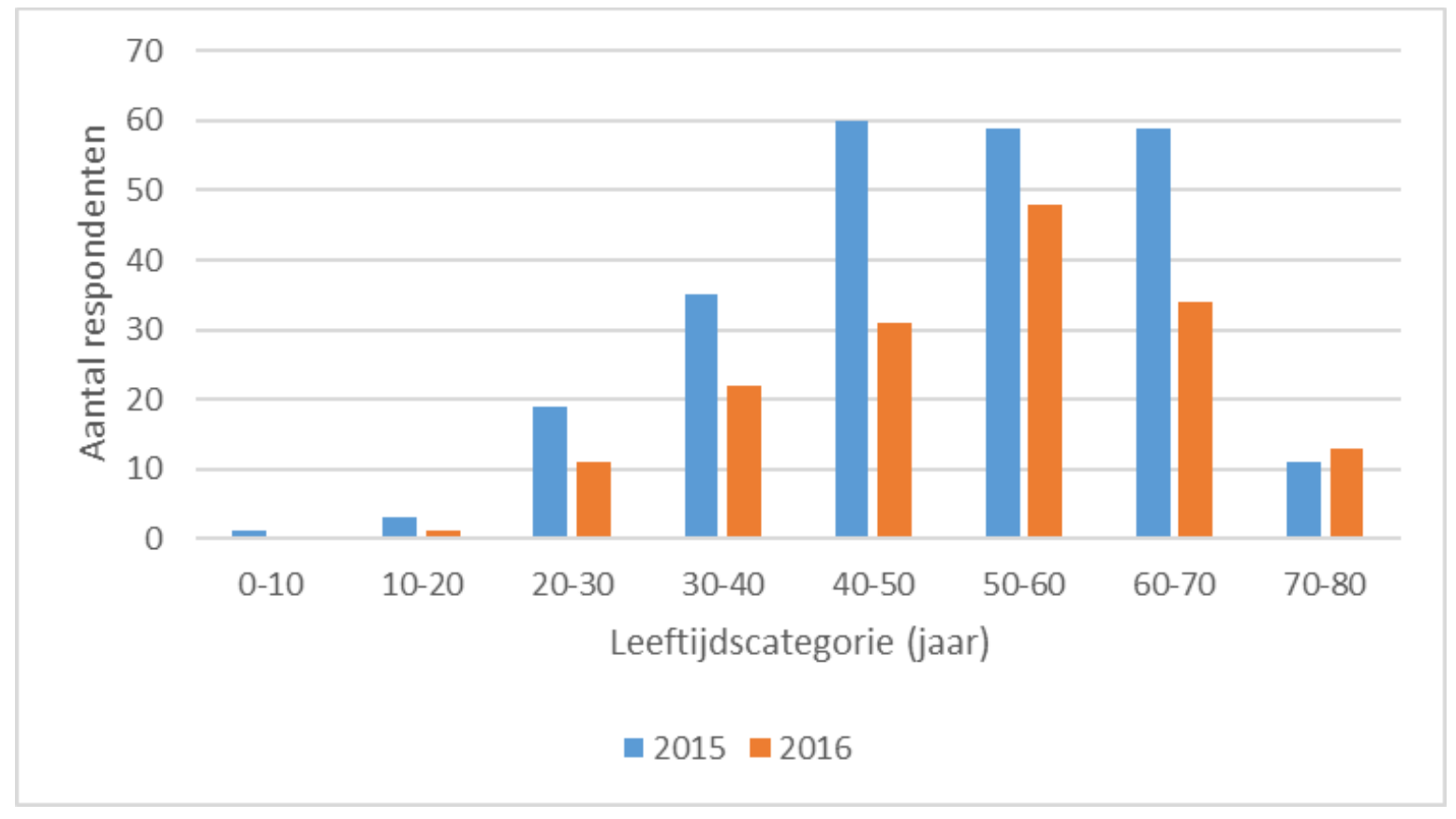

Figuur 11 Leeftijd van de deelnemers van de Beach Clean-up 2015 en 2016 ingedeeld in categorieën van 10 jaar.

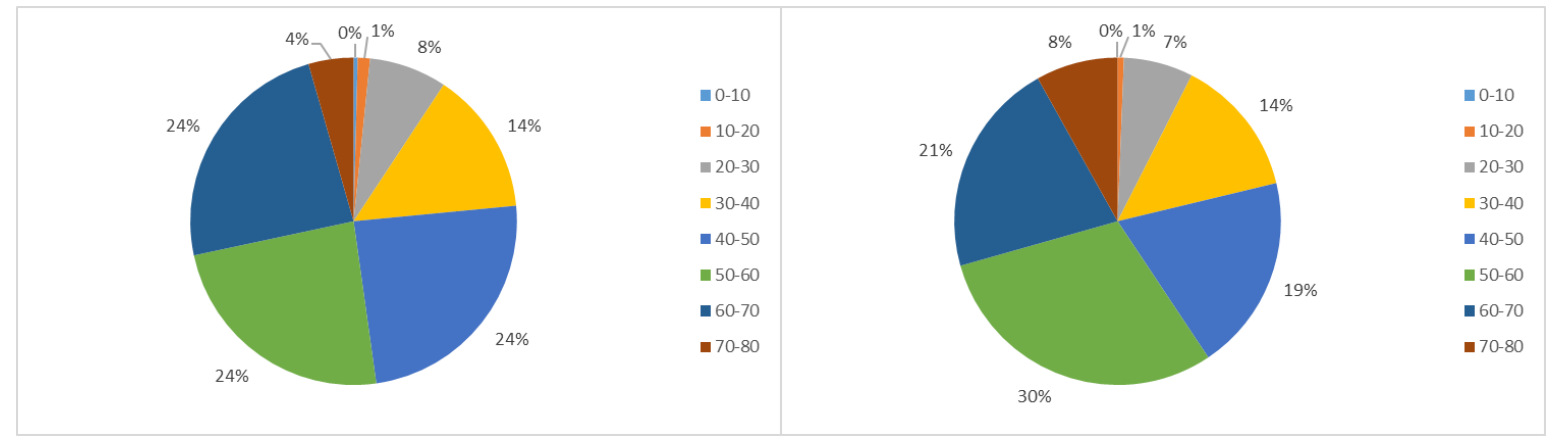

Figuur 12 Verdeling van de leeftijd van de deelnemers van de Beach Clean-up 2015 (links) en 2016 (rechts) ingedeeld in categorieën van 10 jaar.

De verdeling tussen mannen en vrouwen is redelijk gelijk (Figuur 12). De helft van de deelnemers gaf aan een partner te hebben en ongeveer een derde was single (Figuur 13). De meeste deelnemers $(61 \%)$ hebben geen kinderen (Figuur 14). Bij de deelnemers die wel kinderen hebben zijn de kinderen meestal ouder dan 12 jaar. 


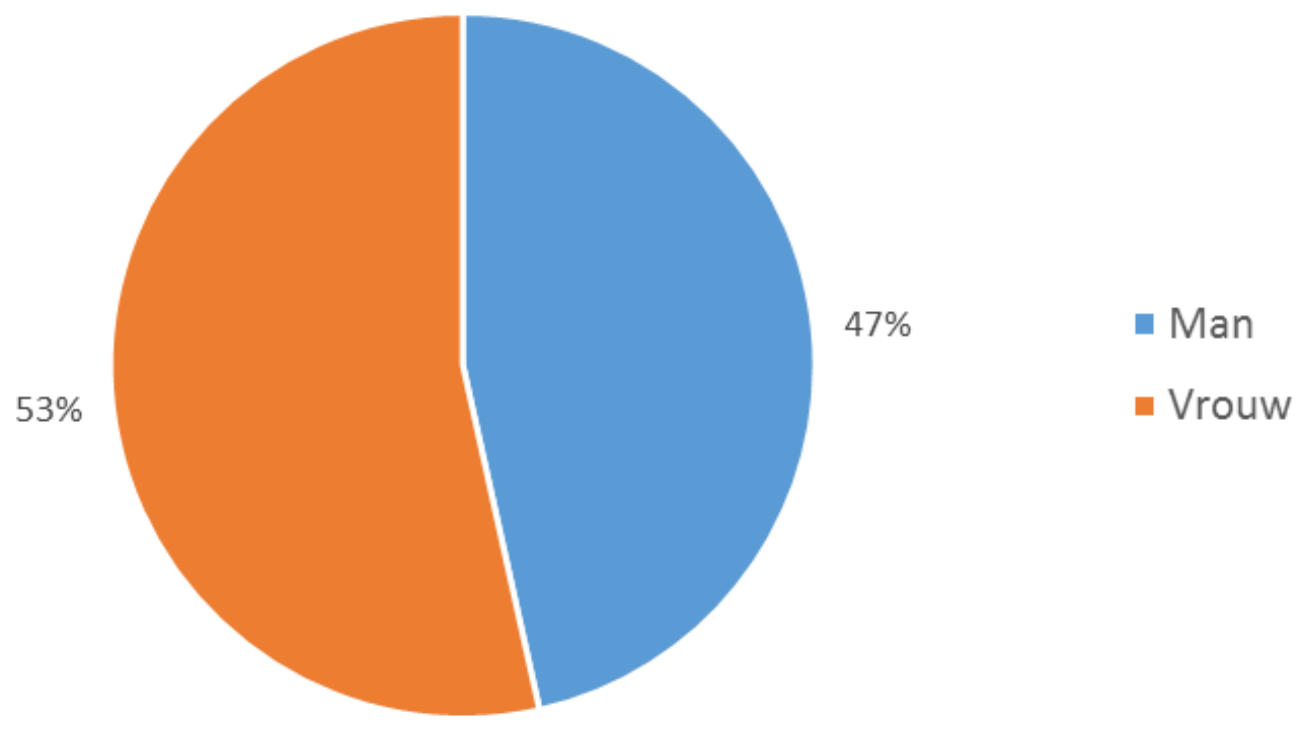

Figuur 13 Geslacht van de deelnemers van de Beach Clean-up 2015.

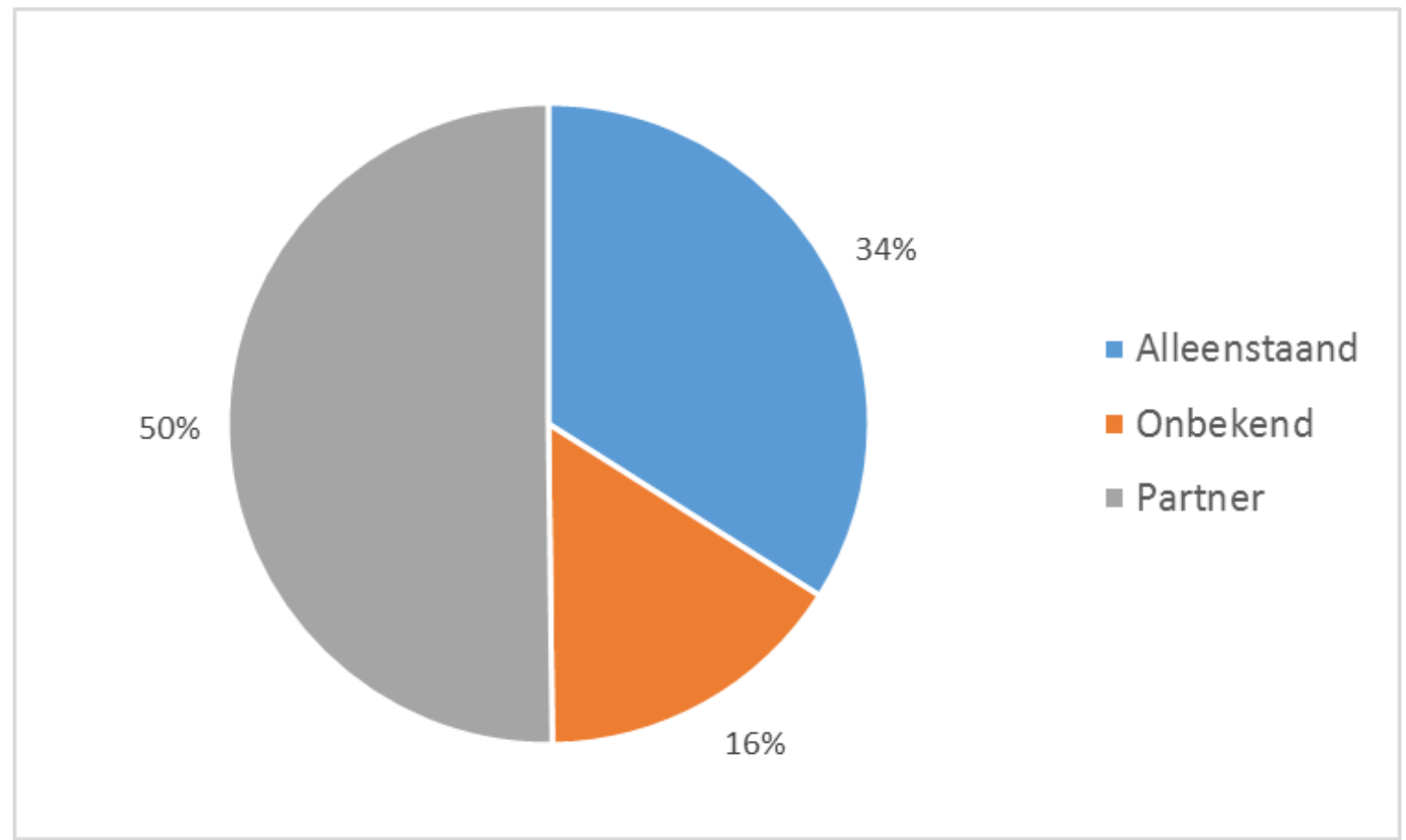

Figuur 14 Status van de deelnemers van de Beach Clean-up 2015. 


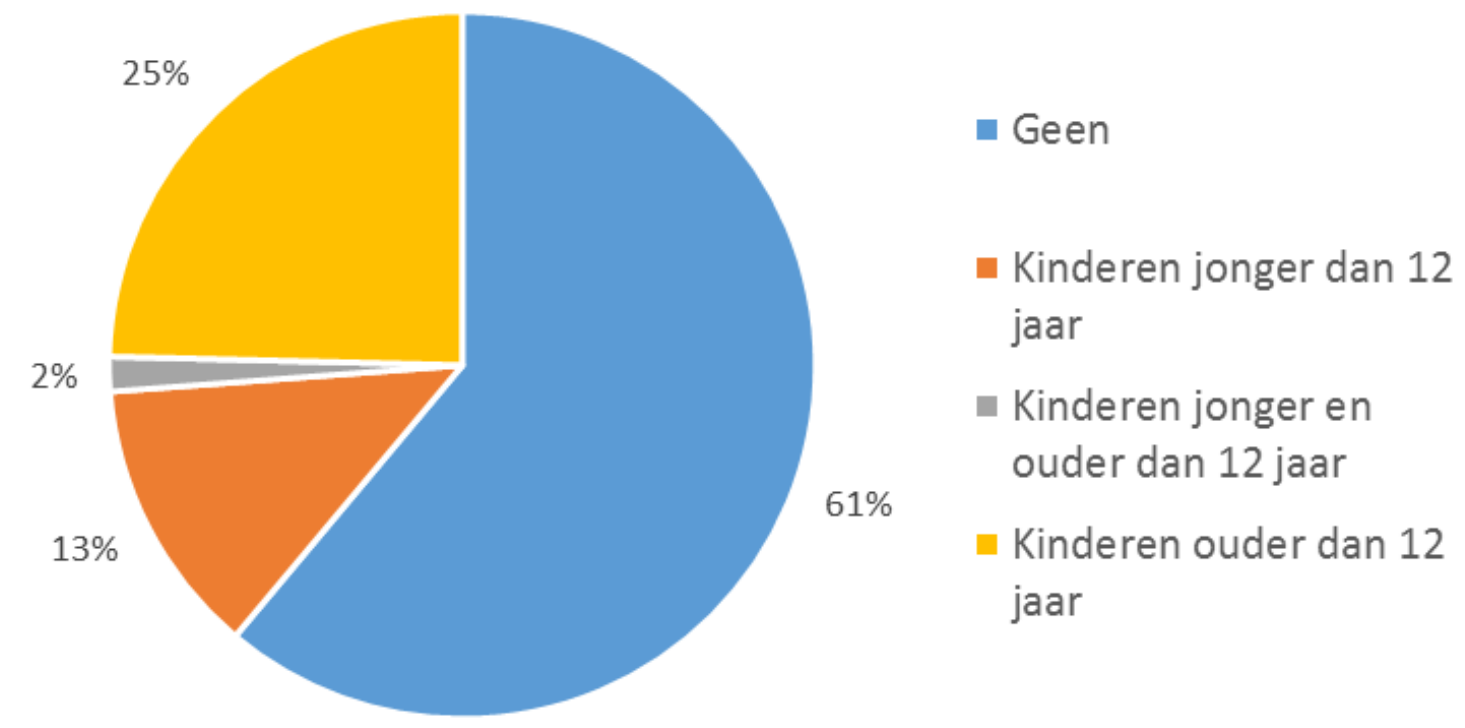

Figuur 15 Gezin van de deelnemers van de Beach Clean-up 2015.

\subsubsection{Woonplaats}

De meeste deelnemers komen uit Noord- en Zuid-Holland (Figuur 15 en Figuur 16). Beide provincies vertegenwoordigen afzonderlijk ruim een derde van het totaal aantal deelnemers (Figuur 17). Dit is te verwachten aangezien deze provincies aan de Noordzeekust liggen. Andere Noordzeekustprovincies (Zeeland, Friesland) scoren echter veel lager. Van de binnenlandse provincies komt een relatief hoog percentage deelnemers uit Utrecht (Figuur 17). Er waren in 2015 twee deelnemers uit het buitenland ( 1 België en 1 Zweden) en in 20161 deelnemers uit het buitenland (België). Deze zijn niet meegenomen in onderstaande figuren.

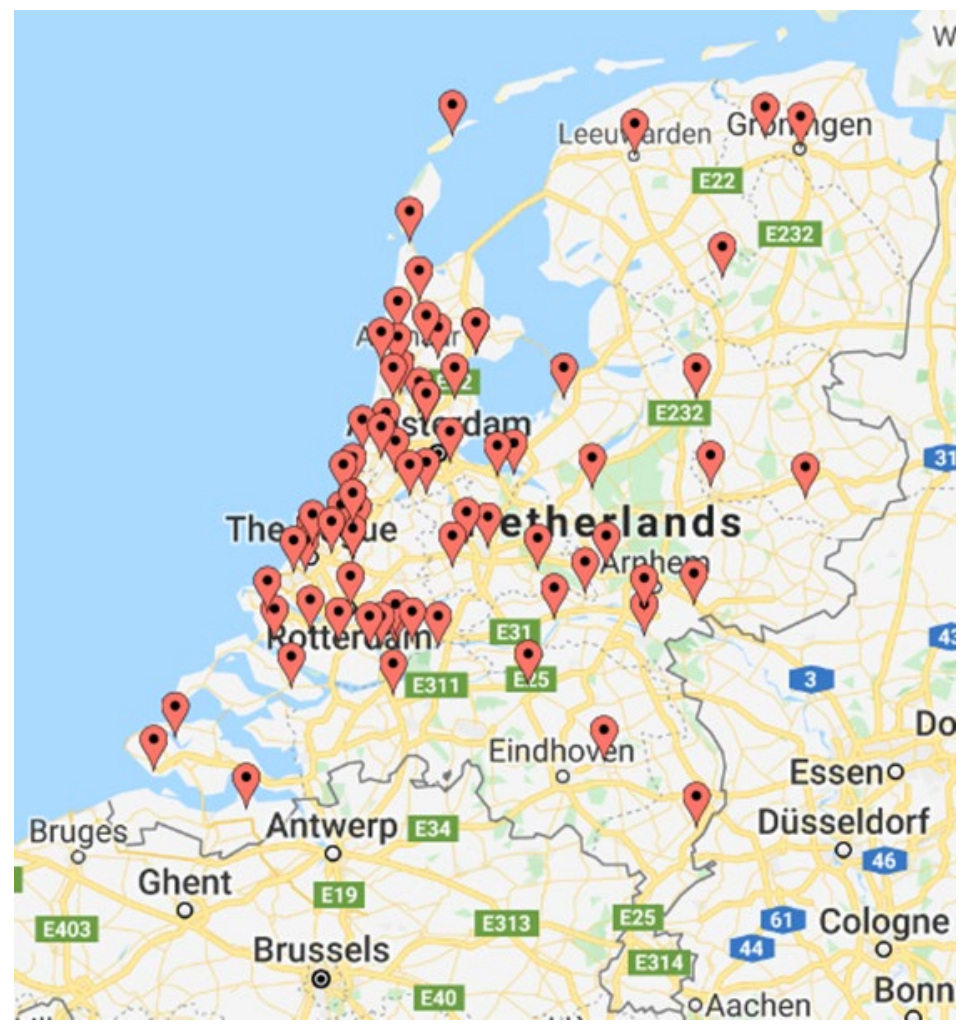

Figuur 16 Woonplaats van de deelnemers van de Beach Clean-up 2016. 


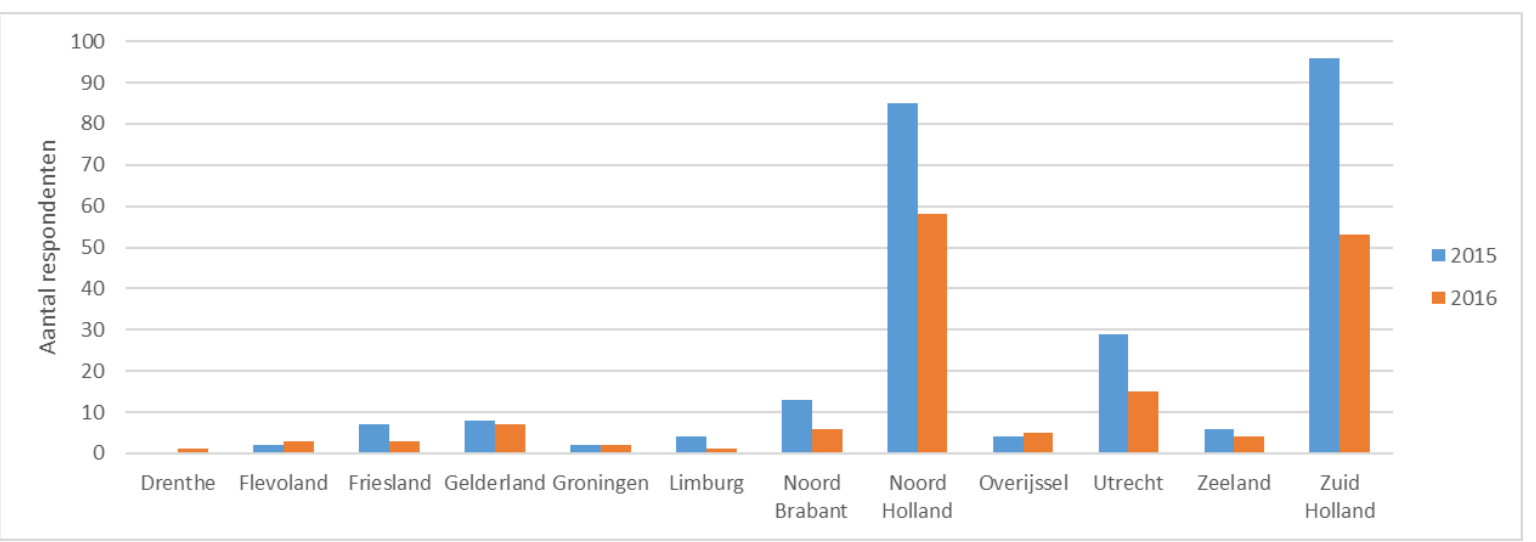

Figuur 17 Woonplaats van de deelnemers van de Beach Clean-up 2015 en 2016, ingedeeld per provincie.

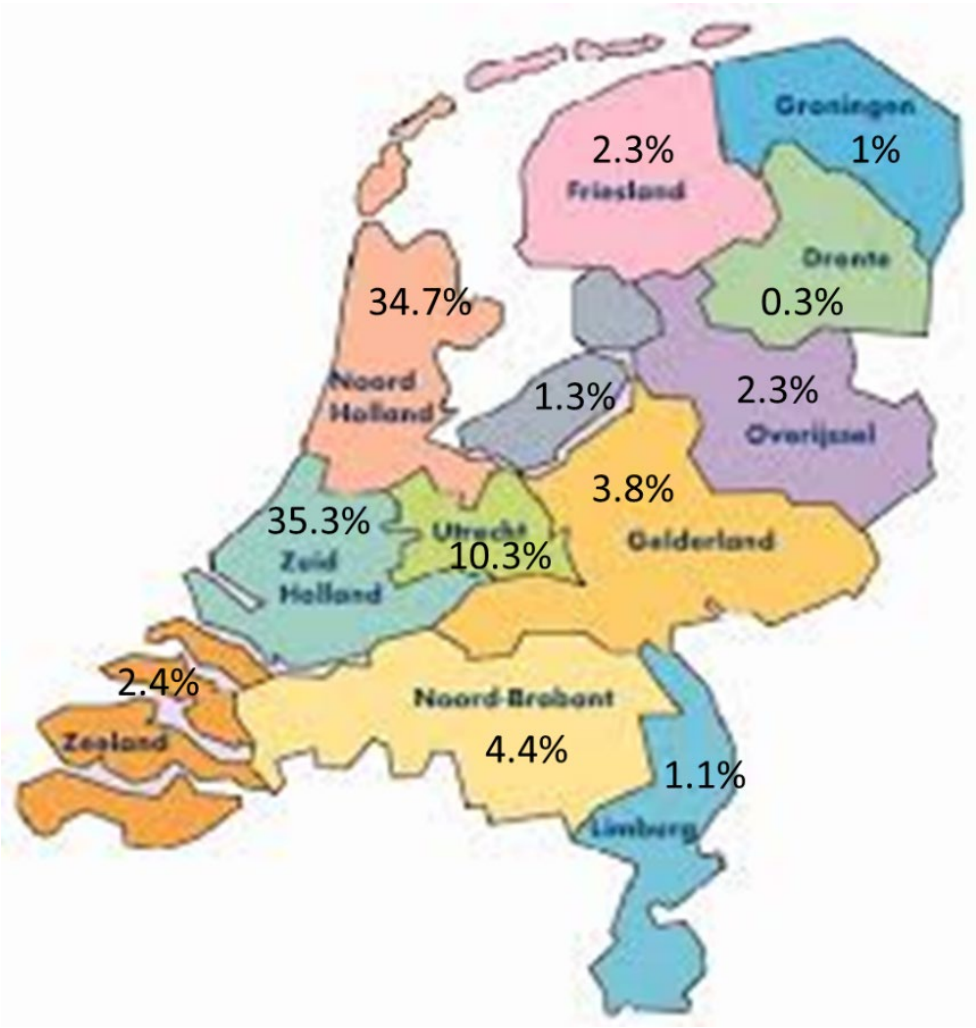

Figuur 18 Herkomst van de deelnemers van de Beach Clean-up in percentage per provincie, gemiddelde van 2015 en 2016.

\subsection{Waar/wanneer/hoe}

In deze paragraaf is weergegeven welke etappes het populairst zijn (4.3.1). Vervolgens, om een beeld te krijgen van de hoeveelheid inzet of moeite de deelnemers er voor over hebben gehad om bij te dragen aan de Beach Clean-up, is gekeken naar de reisafstand (4.3.2), of mensen er speciaal naartoe zijn gereisd (4.3.3), of ze vrij hebben genomen van werk (4.3.4) en naar de wijze van transport (4.3.5).

\subsubsection{Etappes}

Op basis van de resultaten van de enquêtes van 2013 t/m 2019 zijn het aantal deelnemers van de Beach Clean-up per etappe en jaar in kaart gebracht (Figuur 18). Gegevens van het jaar 2015 ontbreken aangezien destijds in de enquête niet is gevraagd aan welke etappes men heeft deelgenomen. Over het algemeen hebben etappes $6 \mathrm{t} / \mathrm{m} 19$ de meeste deelnemers. Van het gemiddeld aantal deelnemers over de periode 2013-2019 heeft etappe 25 (Vlieland) het minimum 
aantal deelnemers en etappe 19 (Petten) het maximum aantal deelnemers (Figuur 18). In 2016 was het traject van etappe $21 \mathrm{t} / \mathrm{m} 28$ relatief populair, ten opzichte van andere jaren en andere trajecten. Dit zijn de eilanden Texel, Vlieland en Terschelling (Figuur 19).

De populairste etappes liggen in Zuid Holland (etappes 5 tot 14) gevolgd door Noord Holland (etappe 15 tot 20), zie Figuur 19 en Figuur 20. De etappes in Zeeland en Friesland zijn een stuk minder populair. Dit komt overeen met de herkomst van de deelnemers; de meeste mensen komen uit Zuiden Noord Holland. Het aantal deelnemers uit Zeeland en Friesland ligt een stuk lager (Figuur 19).

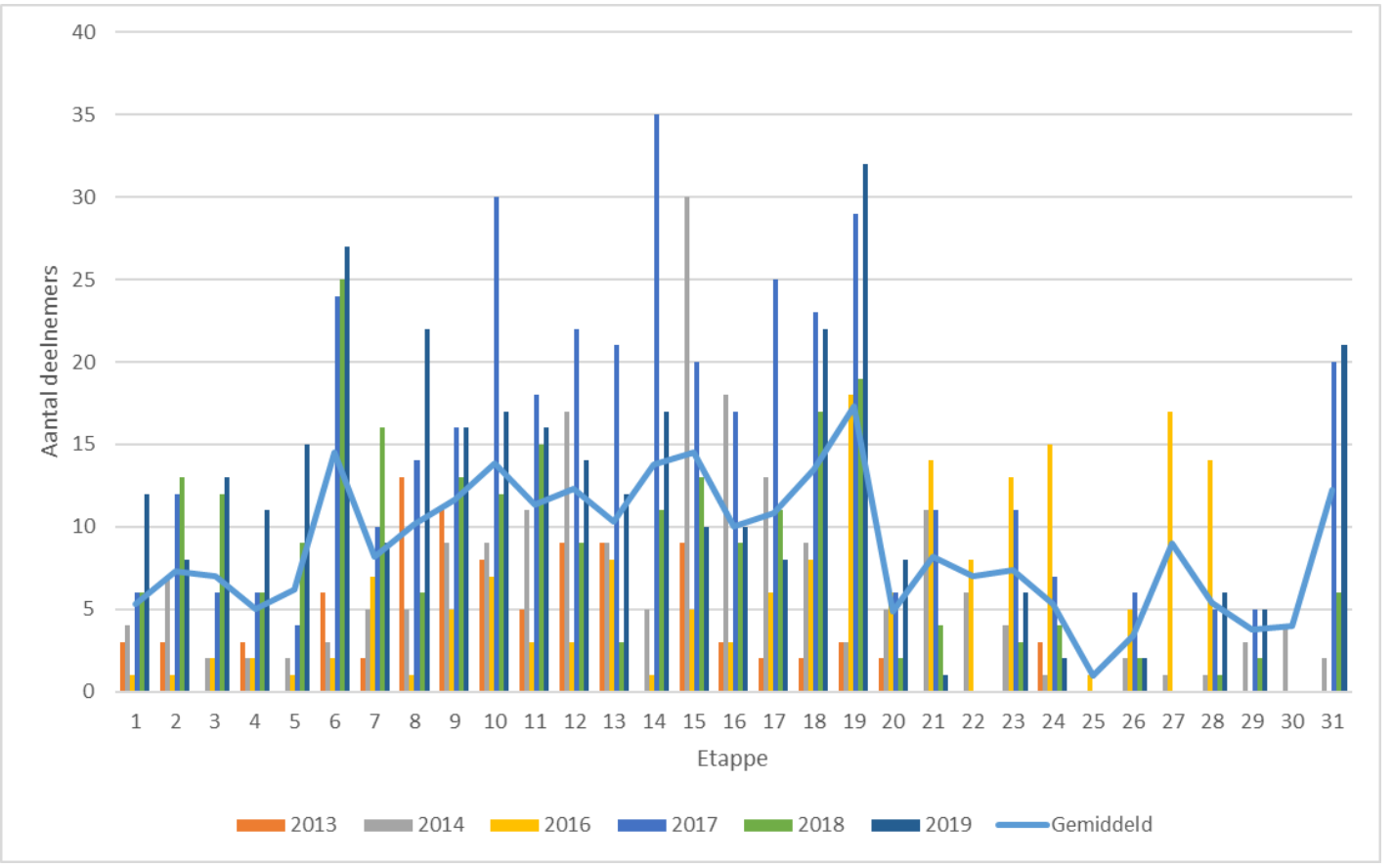

Figuur 19 Aantal deelnemers van de Beach Clean-up per etappe en jaar op basis van de resultaten van de enquêtes van 2013 t/m 2019, met uitzondering van 2015, waar deze vraag ontbreekt. De blauwe lijn geeft het gemiddelde aantal over 2013-2019 per etappe aan. Etappes per provincie: Zeeland 1-4; Zuid Holland 5-14; Noord Holland 15-24; Friesland 25-31. 


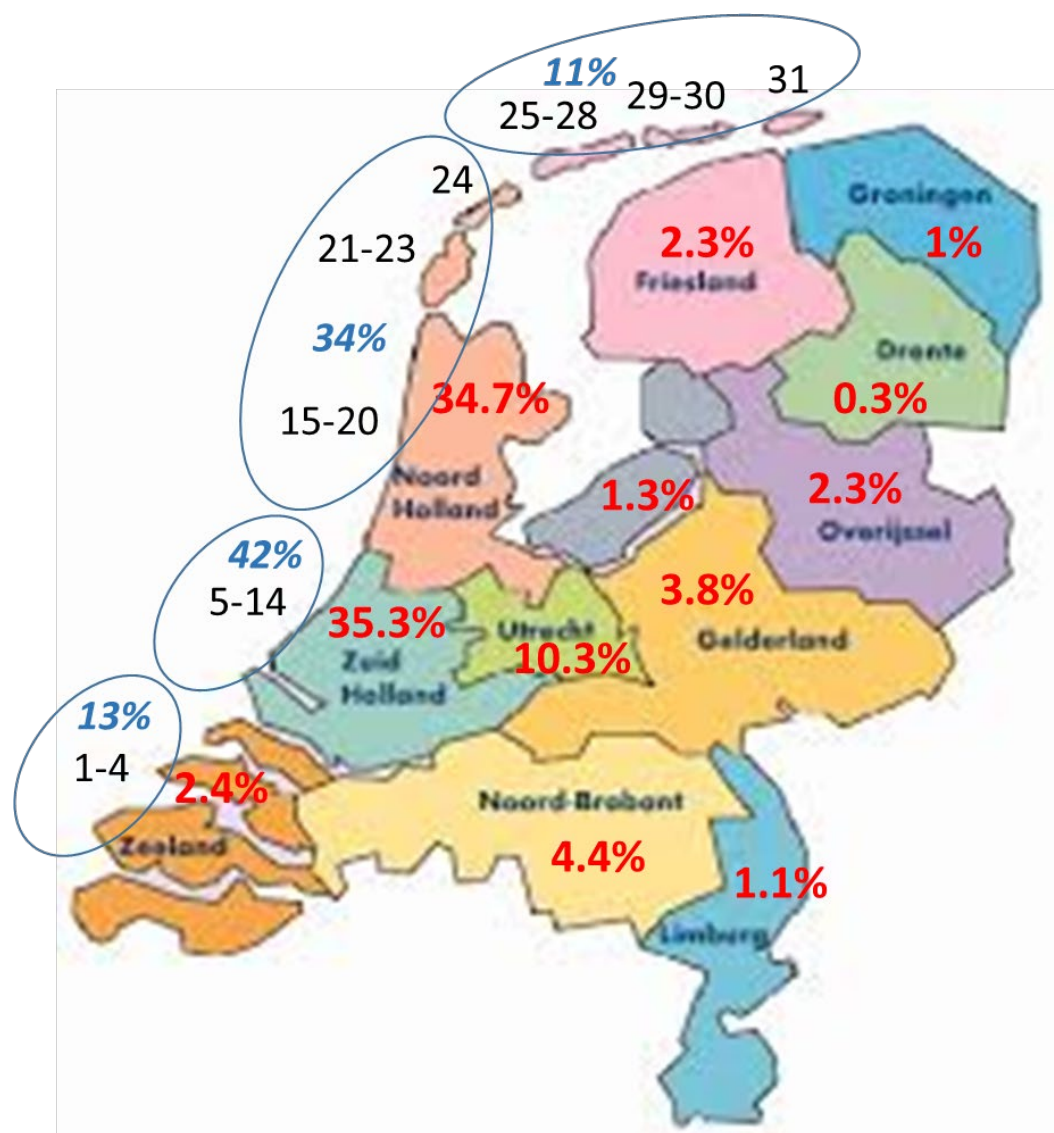

Figuur 20 Verdeling van het aantal deelnemers van de Beach Clean-up etappes per provincie (percentages in blauw cursief) op basis van de resultaten van de enquêtes van $2013 \mathrm{t} / \mathrm{m} \mathrm{2019}$, met uitzondering van 2015, waar deze vraag ontbreekt. De percentages in rood geven de herkomst van de deelnemers aan, op basis van de gegevens van 2015 en 2016. De cijfers in zwart geven de etappes per provincie aan: Zeeland 1-4; Zuid Holland 5-14; Noord Holland 15-24; Friesland 25-31.

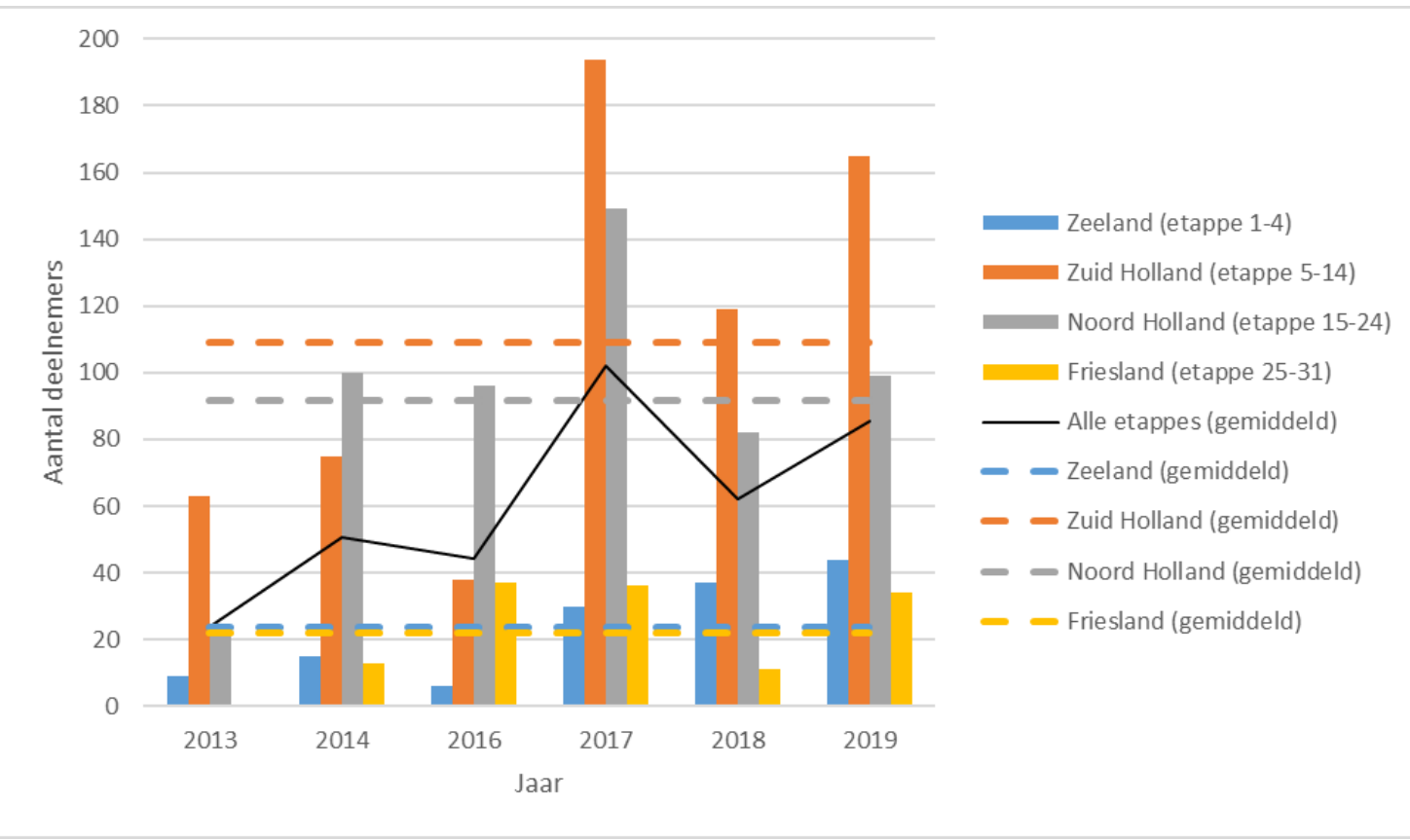

Figuur 21 Aantal deelnemers van de Beach Clean-up etappes ingedeeld per provincie en jaar op basis van de resultaten van de enquêtes van 2013 t/m 2019, met uitzondering van 2015, waar deze vraag ontbreekt. De zwarte lijn geeft het gemiddelde aantal van alle etappes per jaar aan. De gestippelde lijnen geven het gemiddeld aantal deelnemers van de etappes per provincie over de gehele periode. Etappes per provincie: Zeeland 1-4; Zuid Holland 5-14; Noord Holland 15-24; Friesland 25-31. 


\subsubsection{Reisafstand}

$\mathrm{Er}$ is een grote variatie in reisafstand met een minimum van ca. $10 \mathrm{~km}$ en een maximum van $338 \mathrm{~km}$ (Figuur 21). De maximale afstand was voor een deelnemer uit België, die hier waarschijnlijk op vakantie was. De grootste afstand onder Nederlanders was $311 \mathrm{~km}$. De gemiddelde reisafstand was $125 \mathrm{~km}$ per deelnemer. Deze analyse is gebaseerd op de gegevens uit 2016. De reisafstand is de afstand tussen de opgegeven woonplaats en de plaats behorende bij de eerst genoemde etappe (zie Bijlage 2 voor plaatsnamen van etappes). Hierbij is aangenomen dat iedere deelnemer vanaf de woonplaats reist naar de eerst opgegeven etappe.

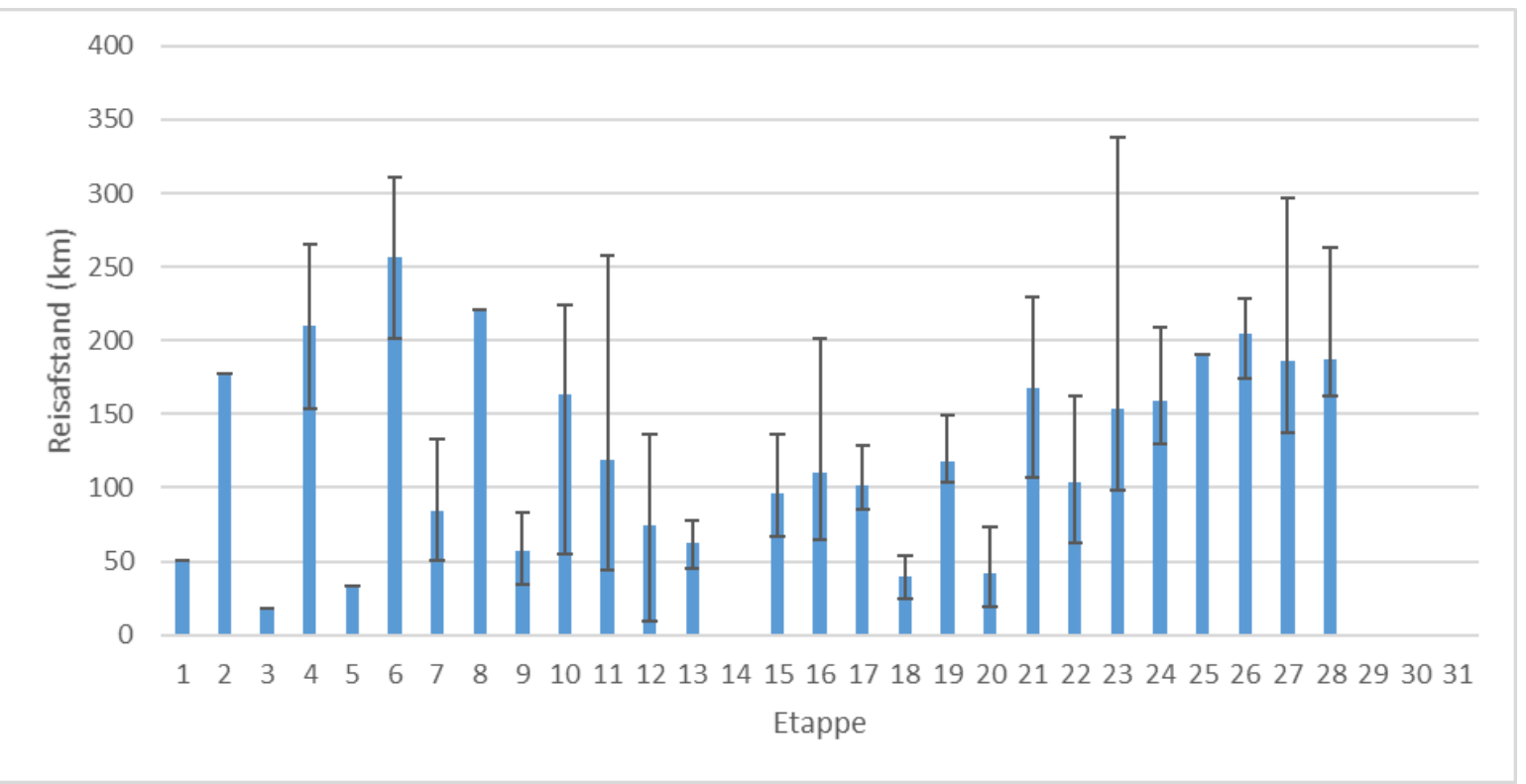

Figuur 22 Gemiddelde reisafstand per etappe van de Beach Clean-up (uitgaande van de afstand tussen de opgegeven woonplaats en de eerste genoemde etappe per deelnemer, op basis van de enquête 2016). De error bars geven de minimale en maximale reisafstand per etappe weer. Etappes per provincie: Zeeland 1-4; Zuid Holland 5-14; Noord Holland 15-24; Friesland 25-31.

In Figuur 22 is het percentage deelnemers van de Beach Clean-up per provincie en het percentage deelnemers verdeeld over de etappes per provincie in kaart gebracht. De provincies Noord- en Zuid Holland zijn zowel in de deelname aan de etappes als in woonplaats het meest voorkomend. 


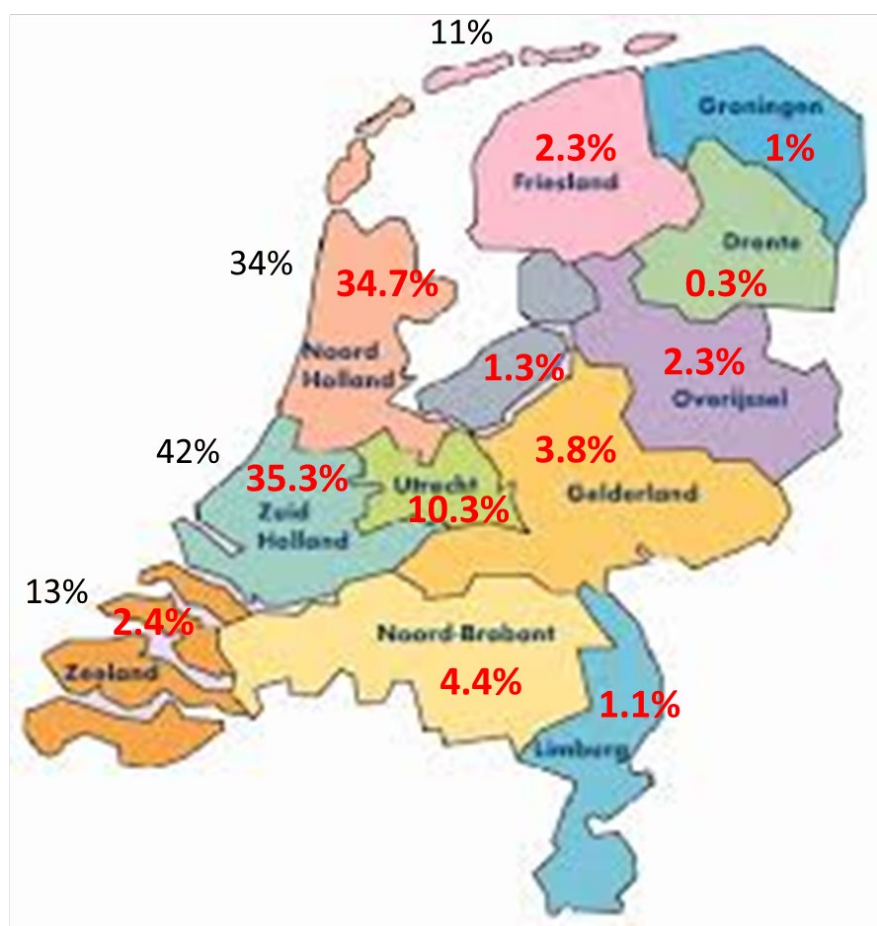

Figuur 23 Woonplaats deelnemers Beach Clean-up per provincie in rood (aantal per provincie ten opzichte van het totaal aantal deelnemers in procent, gemiddelde van 2015 en 2016) en het percentage deelnemers verdeeld over de etappes per provincie (aantal per deeletappe ten opzichte van het totaal aantal deelnemers, gemiddelde van alle jaren (uitgezonderd 2015: geen gegevens)).

\subsubsection{Speciaal er naartoe}

Het percentage respondenten dat heeft aangegeven speciaal naar de Beach Clean-up te zijn gereisd varieert tussen de 31 en $88 \%$ met een gemiddelde van 64\% (Figuur 23). Het grootste deel van de deelnemers reist er dus speciaal naar toe. Andere deelnemers hebbe aangegeven in de buurt te zijn of de deelname te combineren met andere doeleinden zoals vakantie of familiebezoek (Figuur 24). Bij etappe 19 (Petten) is een piek te zien voor deelnemers die er speciaal naartoe reizen.

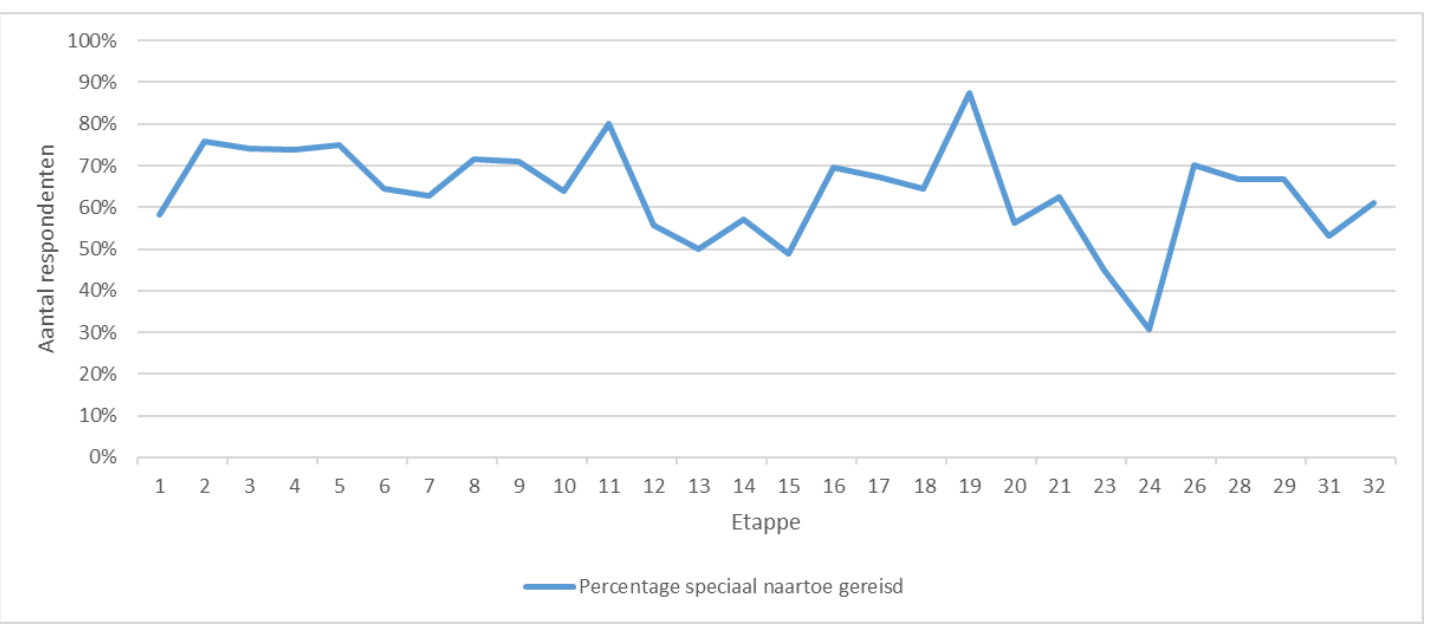

Figuur 24 Het percentage respondenten van de Beach Clean-up dat heeft aangegeven speciaal naar de Beach Clean-up te zijn gereisd. Etappes per provincie: Zeeland 1-4; Zuid Holland 5-14; Noord Holland 15-24; Friesland 25-31. 


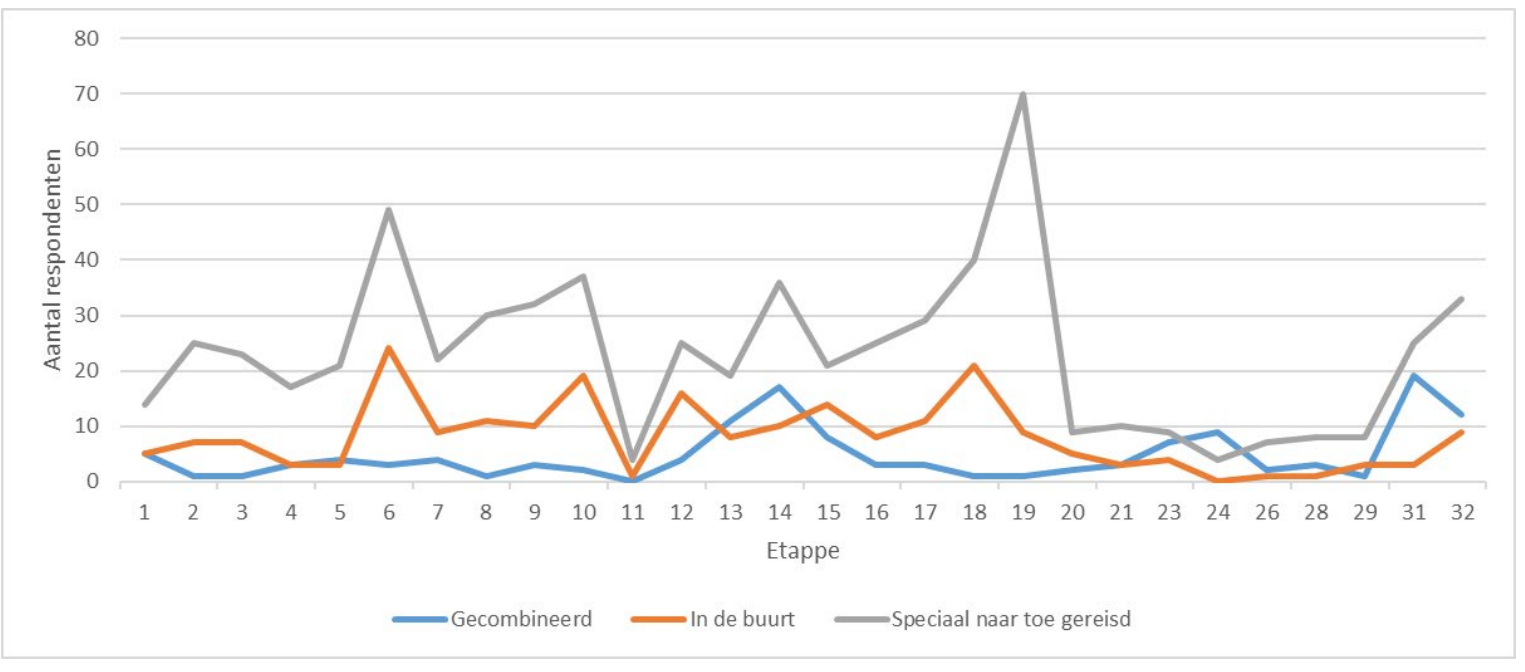

Figuur 25 Het aantal respondenten van de Beach Clean-up dat heeft aangegeven speciaal naar de Beach Clean-up te zijn gereisd, of in de buurt was, of de deelname heeft gecombineerd met bijvoorbeeld vakantie of familiebezoek. Etappes per provincie: Zeeland 1-4; Zuid Holland 5-14; Noord Holland 15-24; Friesland 25-31.

\subsubsection{Vrij genomen van werk}

Meer dan een derde van de respondenten hebben een vrije dag genomen van het werk om mee te kunnen doen (Figuur 25). Deze vraag is alleen in 2017 t/m 2019 gesteld. Er is een stijging in het aandeel van de mensen die een vrije dag hebben genomen ten opzichte van degene die dat niet hebben gedaan (of niet hebben hoeven doen). In 2017 was de verhouding wel/geen vrije dag 0.36, in 2017 was dat 0.37 en in 2019 was de verhouding 0.43 .

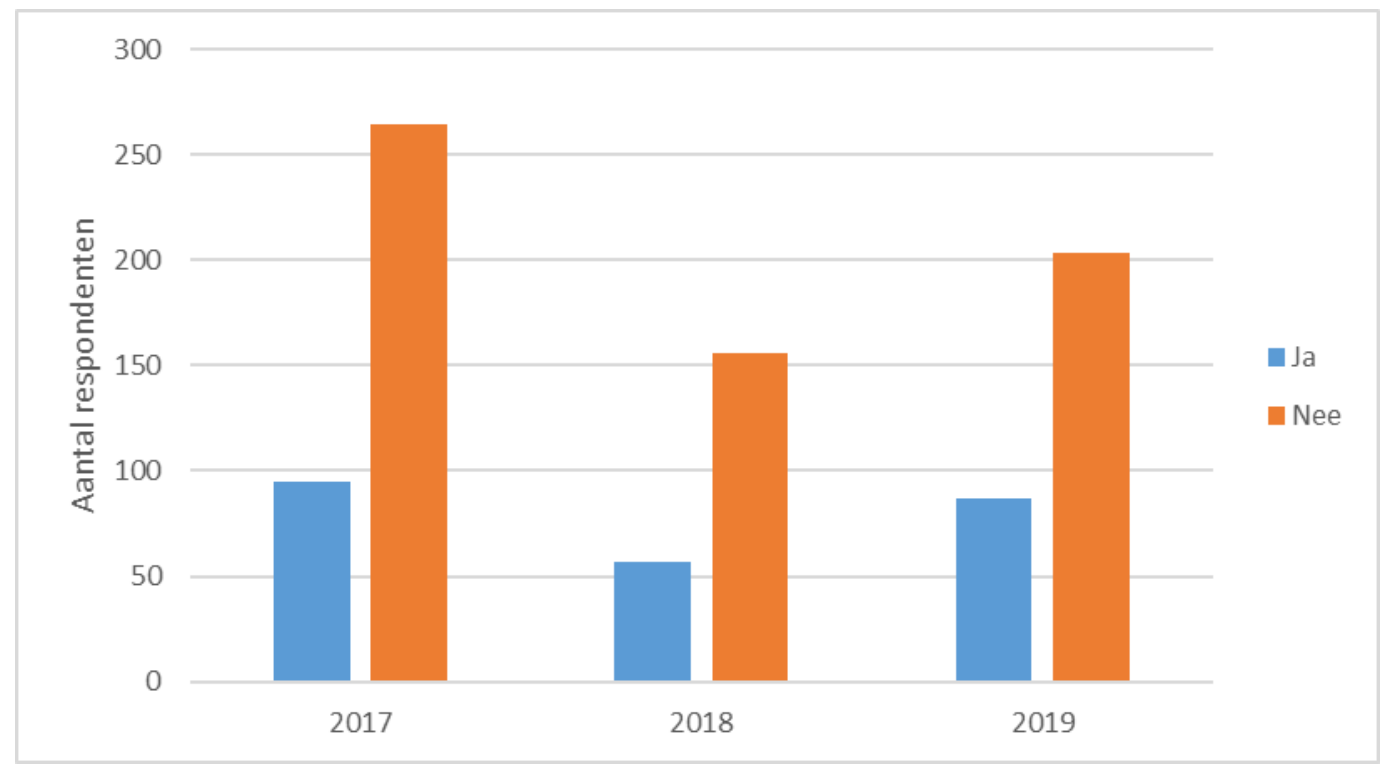

Figuur 26 Het aantal respondenten dat vrij heeft genomen van het werk (blauwe balk, 'ja') en het aantal die dat niet heeft gedaan / niet heeft hoeven doen (oranje balk, 'nee') om mee te doen met de Beach Clean-up in 2017, 2018 en 2019. In andere jaren is deze vraag niet gesteld..

\subsubsection{Wijze van transport}

De meeste deelnemers zijn met de auto naar de Beach Clean-up gekomen (Figuur 26). 


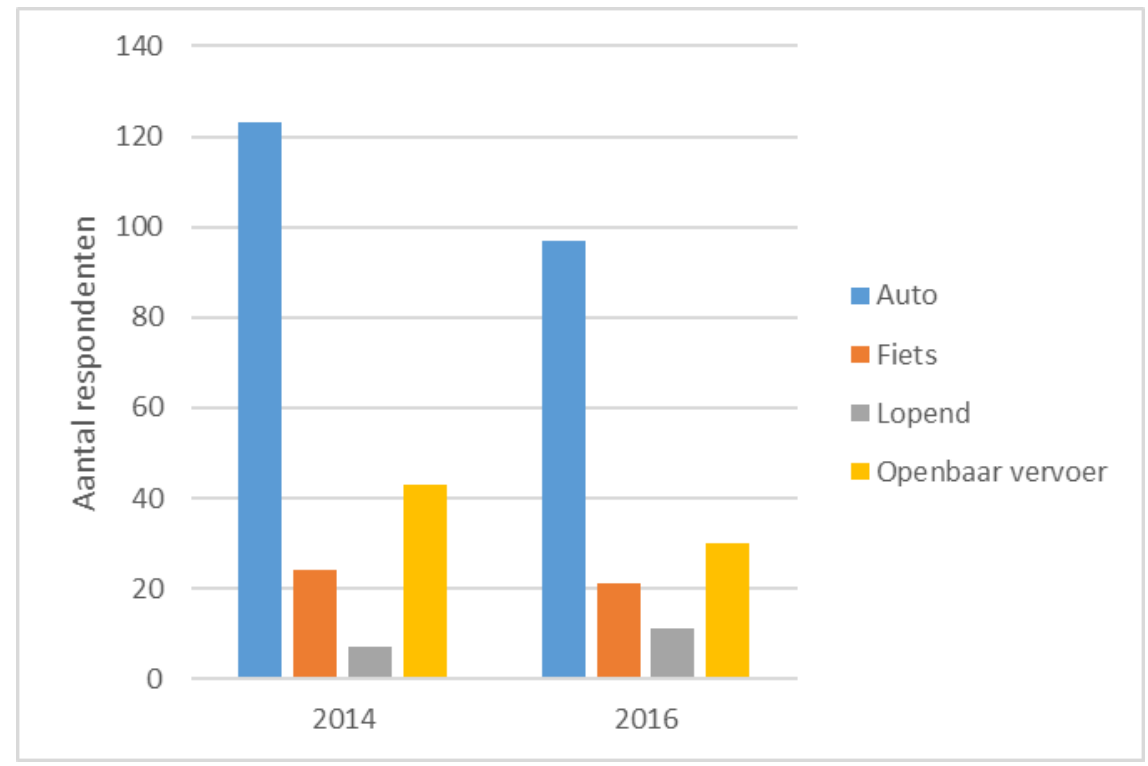

Figuur 27 Het vervoer waarmee de respondenten naar de Beach Clean-up zijn gekomen in 2014 en 2016. In andere jaren is deze vraag niet gesteld.

\subsection{Motivatie}

\subsubsection{Aantal motivaties}

De respondenten konden meerdere motivaties opgeven. De verdeling van het aantal motivaties dat de respondenten hebben opgegeven over de verschillende jaren laat zien dat de meeste respondenten maar 1 motivatie opgeven (Figuur 27). Het maximum aantal motivaties was 6. In 2016 hebben alle respondenten slechts één motivatie opgegeven. Waarschijnlijk was het dat jaar niet mogelijk om meerdere antwoorden te geven.

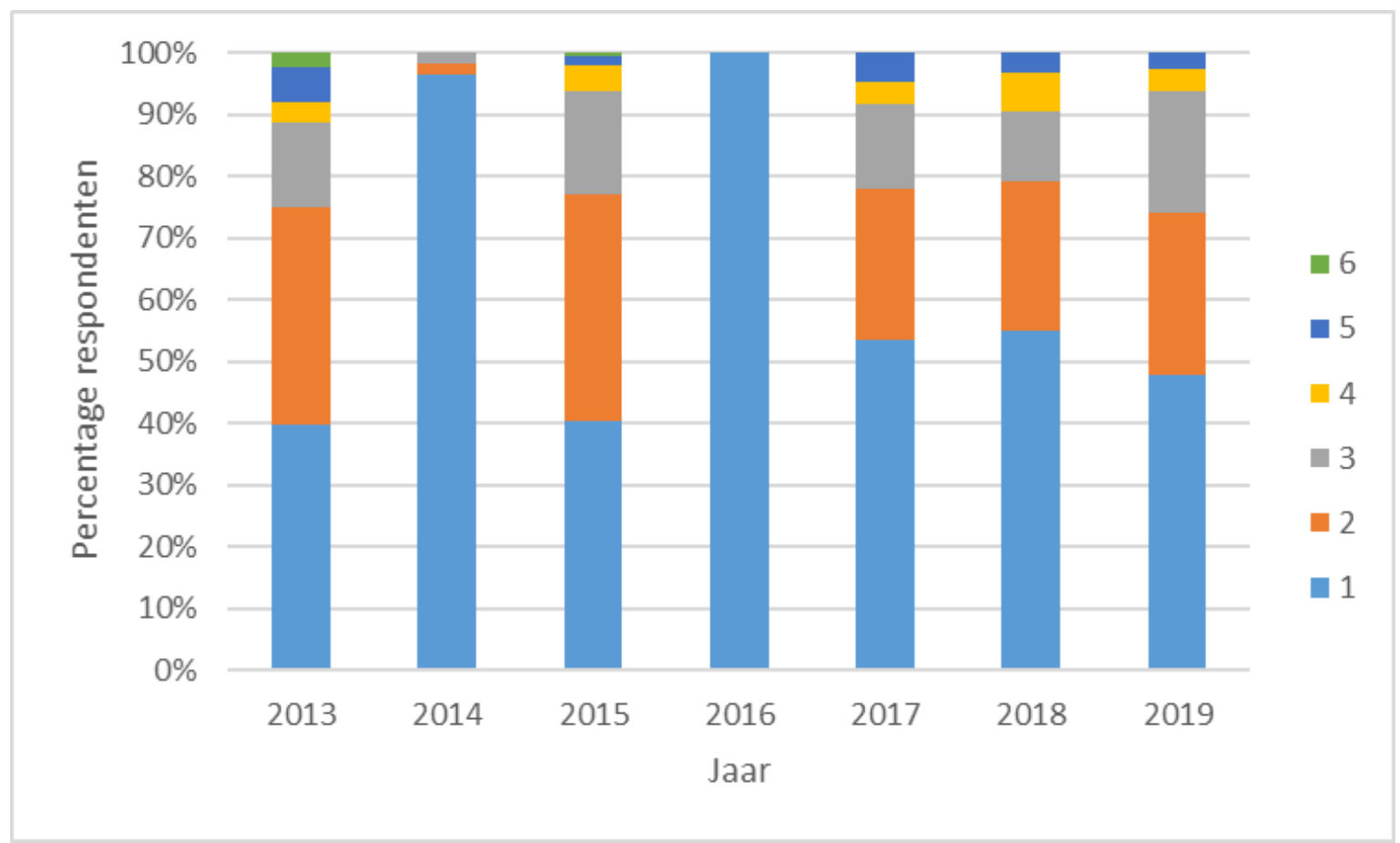

Figuur 28 Het aantal motivaties per respondent uitgedrukt in percentage van de Beach Clean-up respondenten per jaar. De kleuren geven het aantal motivaties aan. 


\subsubsection{Type motivaties}

Het aantal motivaties van de Beach Clean-up respondenten per motivatiecategorie is voor elk jaar en gemiddeld over de hele periode in een taartdiagram weergegeven (Figuur 28).

Een belangrijke motivatie die wordt gegeven door de respondenten is iets doen aan de plastic soep (Figuur 28), welke in bijna alle jaren het meest genoemd wordt als motivatie. Bij de start van de Beach Clean-up in 2013 was het percentage van de motivatie 'plastic soep' ten opzichte van alle motivaties met $30 \%$ het laagst. De jaren daarna was het percentage veel hoger, met uitschieters van $76 \%$ in 2014 en $74 \%$ in 2016. De laatste jaren ( $2017 \mathrm{t} / \mathrm{m} \mathrm{2019)}$ is het aandeel vrij stabiel en varieert tussen de $41 \%$ en $44 \%$. De motivatie heeft een stijgende trend over de periode 2013-2019 (Figuur 29). Verder valt op dat sinds 2017 de motivaties in de categorie 'opruimen, schoon strand, actie ondernemen' een belangrijk aandeel heeft, terwijl dat in de periode 2013-2016 nauwelijks een rol speelde. Goed doen voor de natuur heeft ook een belangrijk aandeel in de motivatie en scoorde zeer hoog bij de eerste Beach Clean-up in 2013. De daarop volgende jaren, van 2014 t/m 2016, speelde het nauwelijks tot geen rol waarna in 2017 en daarna weer een aanzienlijk deel van de respondenten 'goed doen voor de natuur' als motief aangaf ( $16 \%$ tot $18 \%$ van alle motivaties). Een laatste belangrijke motivatiecategorie is sportief, gezond en gezellig, met een sterke piek in 2015 (48\%) en een dieptepunt het jaar daarop (6\% in 2016). De verdeling van motivaties is vrij stabiel de laatste jaren (2017 t/m 2019).

De motivaties die de Beach Clean-up respondenten hebben aangegeven, zijn vervolgens ook onderverdeeld in twee hoofdcategorieën: motivaties gericht op natuur/milieu (o.a. plastic soep, opruimen) en motivaties gericht op menselijke aspecten (gezellig, sportief, werk). De verhouding tussen motivaties gericht op natuur/milieu en motivaties gericht op menselijke aspecten (Figuur 30) geeft inzicht in de onderliggende drijfveer van de mensen: gaat het om de natuur te helpen of om de gezelligheid en sportiviteit? Met uitzondering van 2015 is elk jaar de natuur verreweg de grootste motivatie, met ongeveer 2 tot 6 keer vaker dan menselijke aspecten. Er is ook een stijgende trend in de verhouding natuur/mens gerichte motivatie. De natuur lijkt dus een steeds grotere rol te spelen voor mensen om in actie te komen. Echter, aangezien het totaal aantal respondenten ook een stijgende trend laat zien (Figuur 29), kan dit een vertekend beeld geven van de verandering in motivatie over de jaren. Om een zo duidelijk mogelijk beeld te krijgen van een eventuele verandering in motivatie, is daarom ook een relatief overzicht gemaakt door het aantal antwoorden per motivatie categorie te delen door het totaal aantal antwoorden (Figuur 31) en door het totaal aantal respondenten (Figuur 32). 


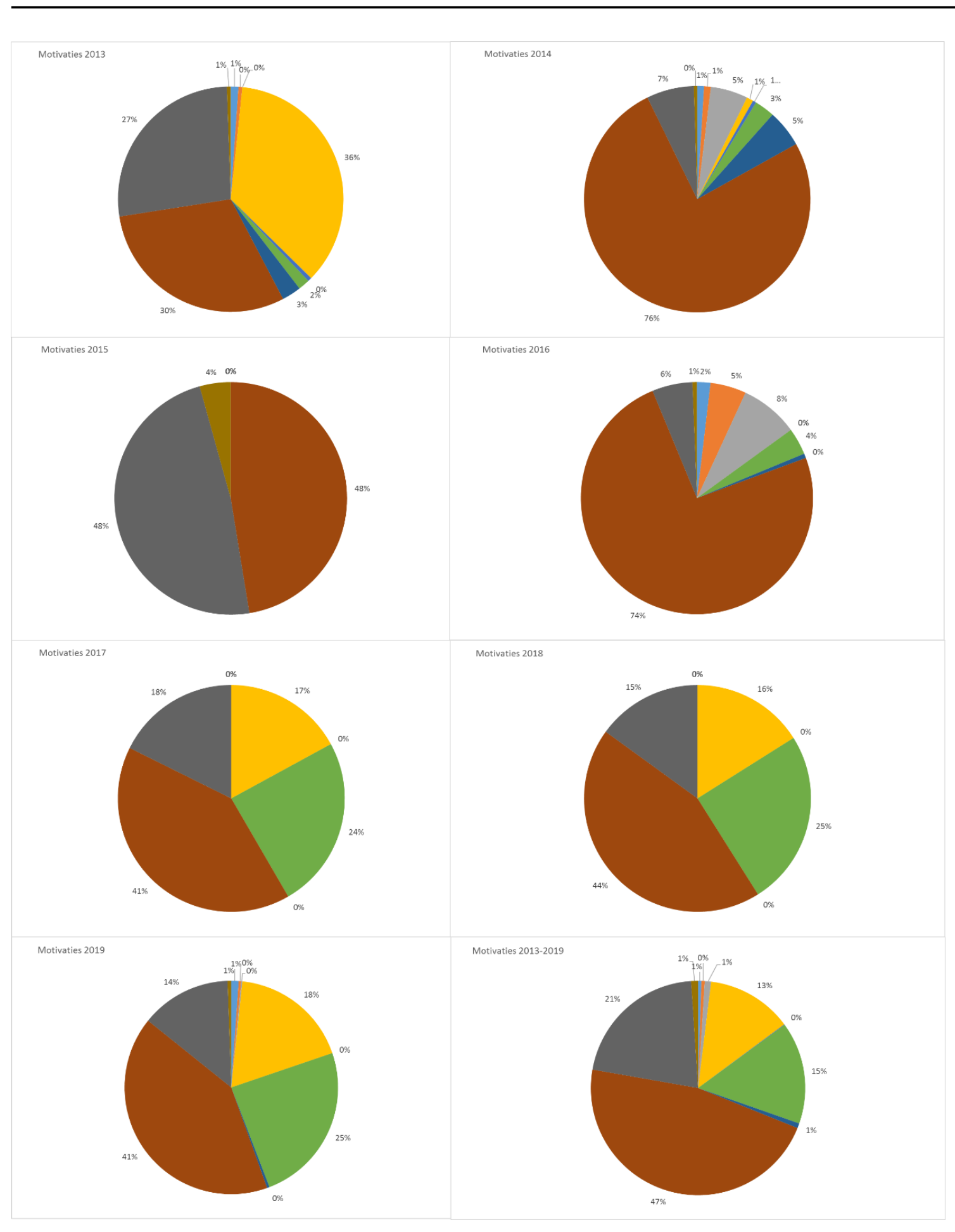

\author{
- Bewustwording \\ Educatief \\ - Netwerken \\ - Overig \\ - Sportief, gezond en gezellig
}

\author{
- Combinatie natuur/milieu en sportief/gezond/gezellig \\ - Goed doen (natuur, milieu, samenleving, St. de NZ) \\ - Opruimen, schoon strand, actie ondernemen \\ - Plastic soep \\ - Werk
}

Figuur 29 Het aandeel (\%) motivaties van de Beach Clean-up respondenten per motivatiecategorie per jaar (2013 (linksboven) tot en met 2019 (linksonder)) en gemiddeld over de periode 2013-2019 (rechtsonder). De kleuren geven de motivatiecategorieën aan. 


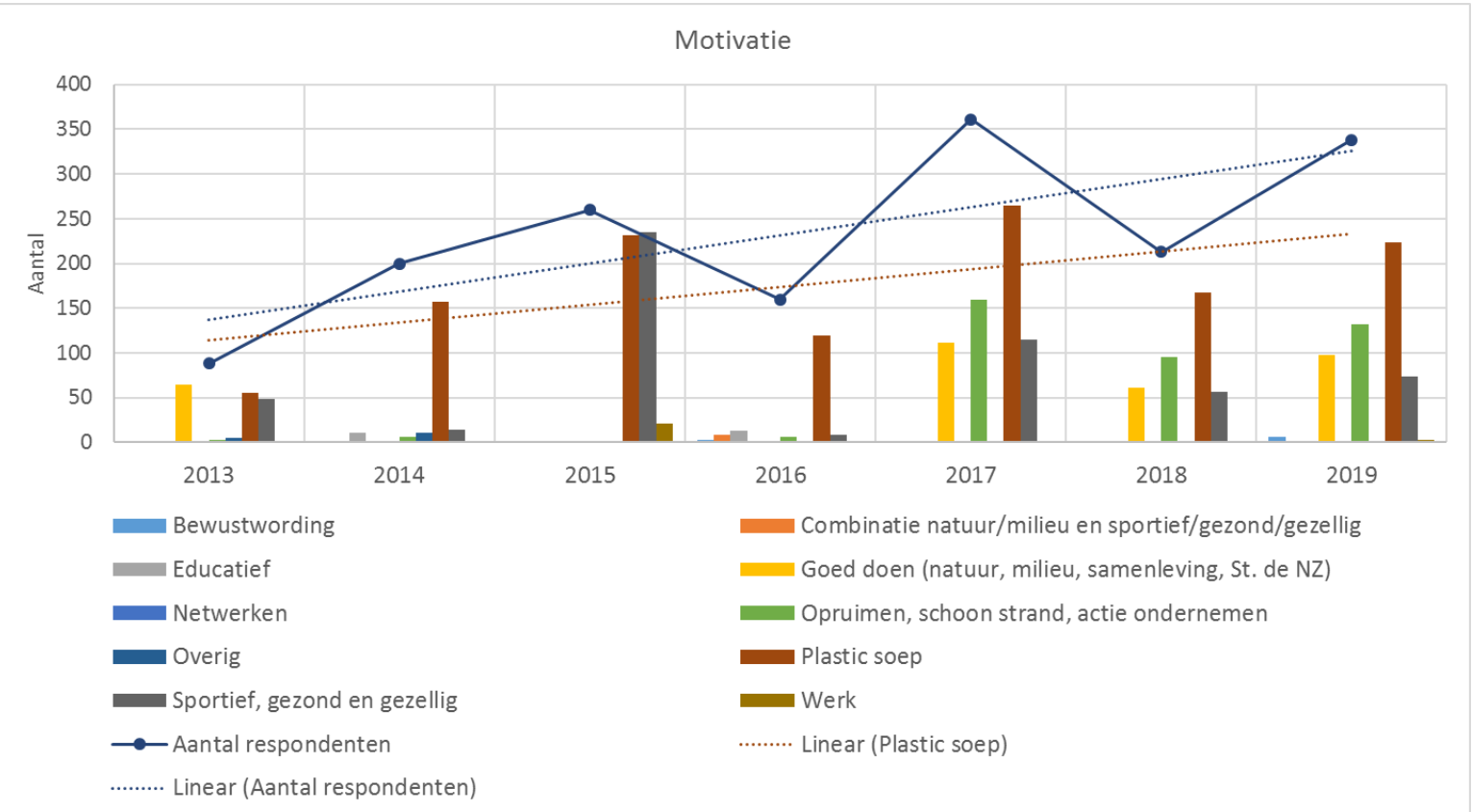

Figuur 30 Aantal motivaties van de Beach Clean-up respondenten per categorie (zie Bijlage 1 Enquêtevragen). Het aantal respondenten is aangegeven door de blauwe lijn. De stippellijnen geven de lineaire trend aan (Excel functie) voor het aantal respondenten (blauwe stippellijn) en het aantal 'plastic soep motivaties' (rode stippellijn). Meerdere motivaties per respondent zijn mogelijk.

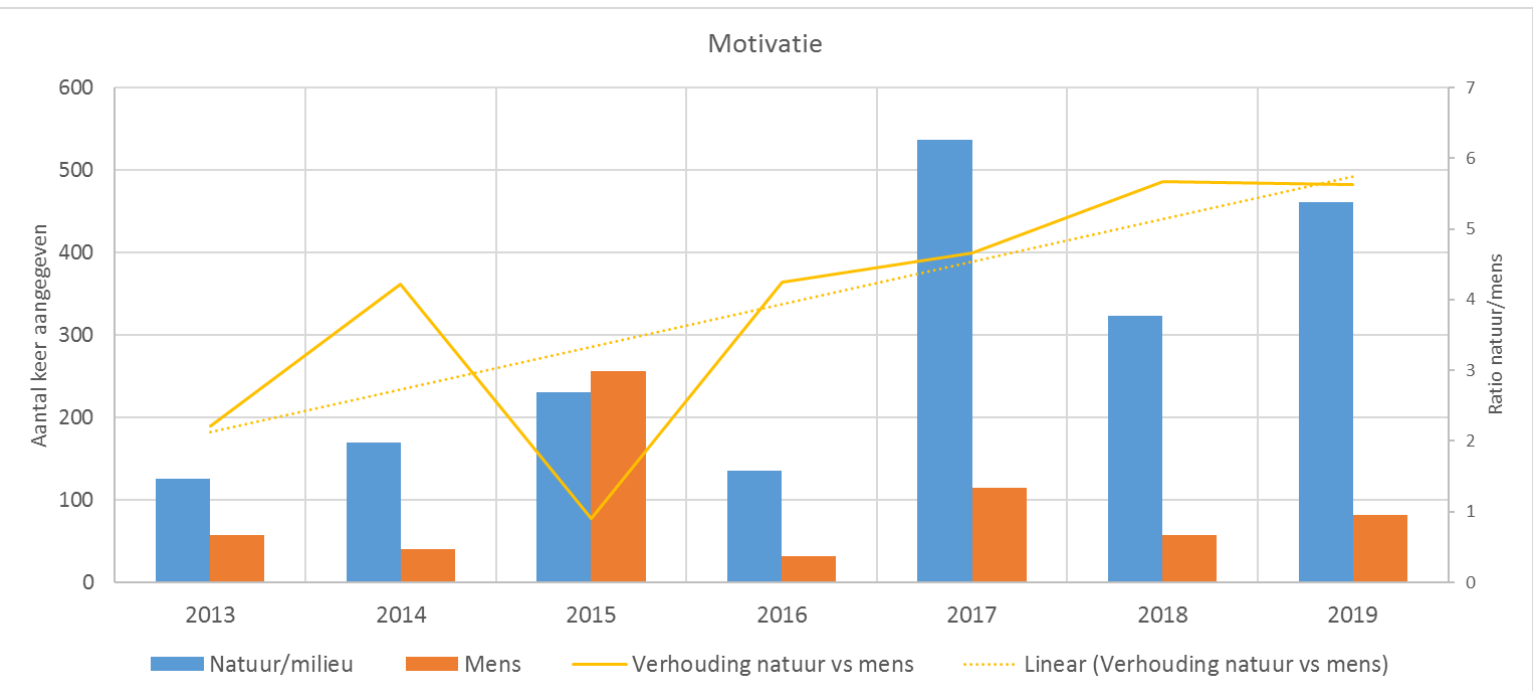

Figuur 31 Aantal motivaties van de Beach Clean-up respondenten per hoofdcategorie. De verhouding tussen motivaties gericht op natuur/milieu (o.a. plastic soep, opruimen) en motivaties gericht op menselijke aspecten (gezellig, sportief, werk) is aangegeven door de gele lijn, waarbij de geel gestippelde lijn de trend aangeeft. Meerdere motivaties per respondent zijn mogelijk.

Relatief gezien laat de verandering van de motivatie over de jaren een ander beeld zien, waarbij de motivatie 'Plastic soep' relatief per antwoord (Figuur 31) een dalende trend laat zien en relatief per respondent (Figuur 32) een neutrale trend. Relatief gezien is de motivatie voor een schoon strand en actie te ondernemen sterk gestegen van 2013 tot 2019. 
Motivatie, relatief

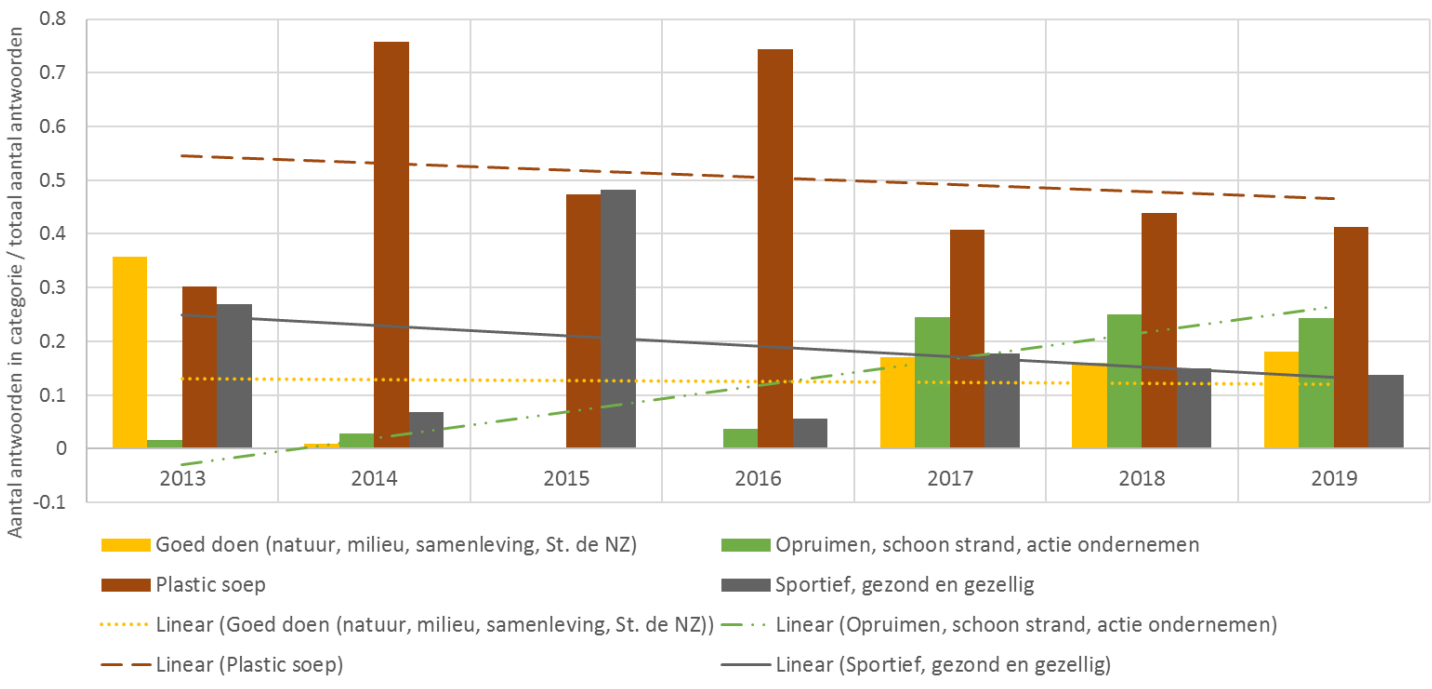

Figuur 32 Aantal motivaties van de Beach Clean-up per categorie gedeeld door het totaal aantal antwoorden. Alleen de 4 grootste categorieën (met het meest aantal antwoorden) zijn weergegeven. Voor elke categorie is de trend weergegeven (m.b.v. Excel functie). Meerdere motivaties per respondent zijn mogelijk.

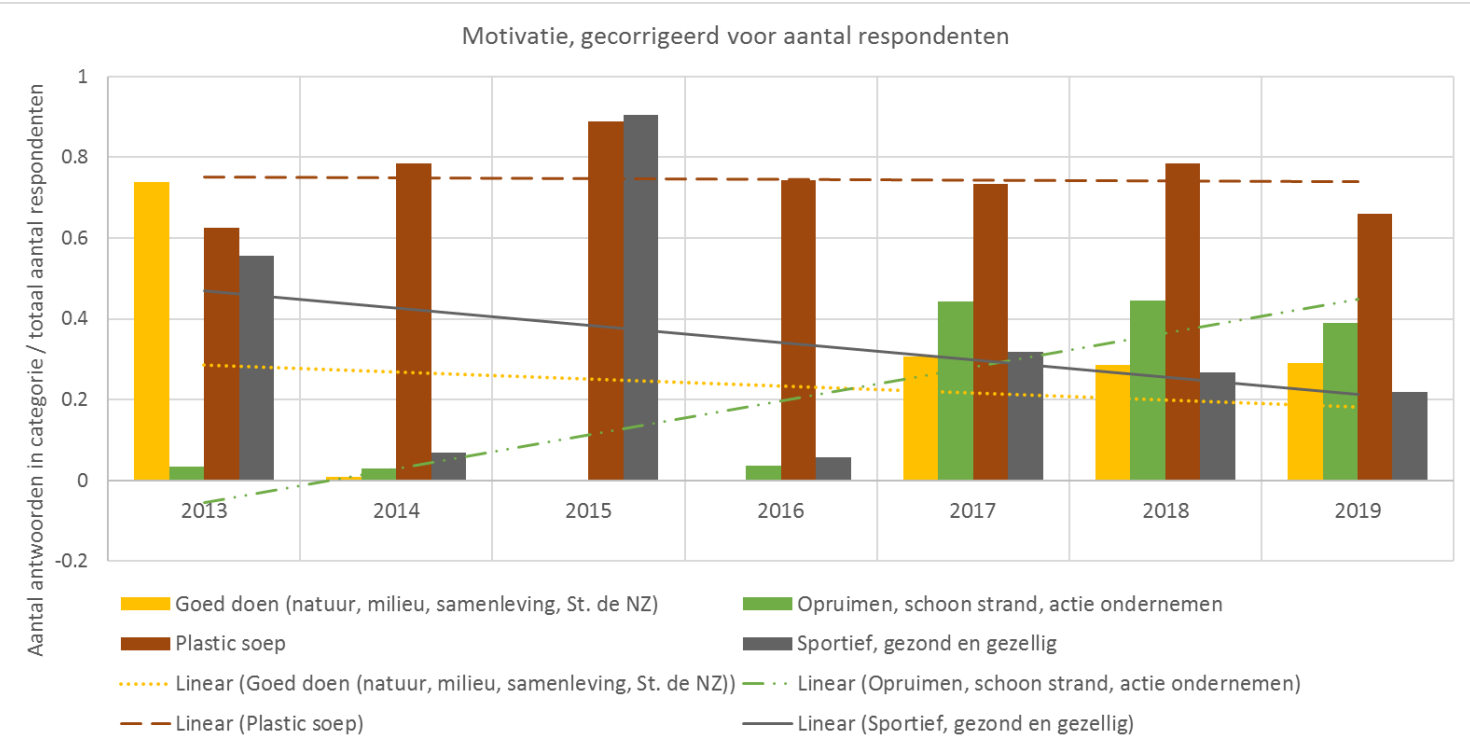

Figuur 33 Aantal motivaties van de Beach Clean-up per categorie gedeeld door het totaal aantal respondenten. Alleen de grootste categorieën (met het meest aantal antwoorden) zijn weergegeven. Voor elke categorie is de trend weergegeven (m.b.v. Excel functie). Meerdere motivaties per respondent zijn mogelijk.

\subsubsection{Plastic soep in het nieuws}

De motivatie om iets te doen aan de plastic soep onder de respondenten en de aandacht voor plastic soep in het nieuws nemen beide toe in de periode 2013-2019 (Figuur 33). De stijging van plastic soep in het nieuws is iets groter en minder variabel dan de stijging van plastic soep als motivatie. Er lijkt wel een relatie te zijn tussen de motivatie en de aandacht in het nieuws (Figuur 34). 


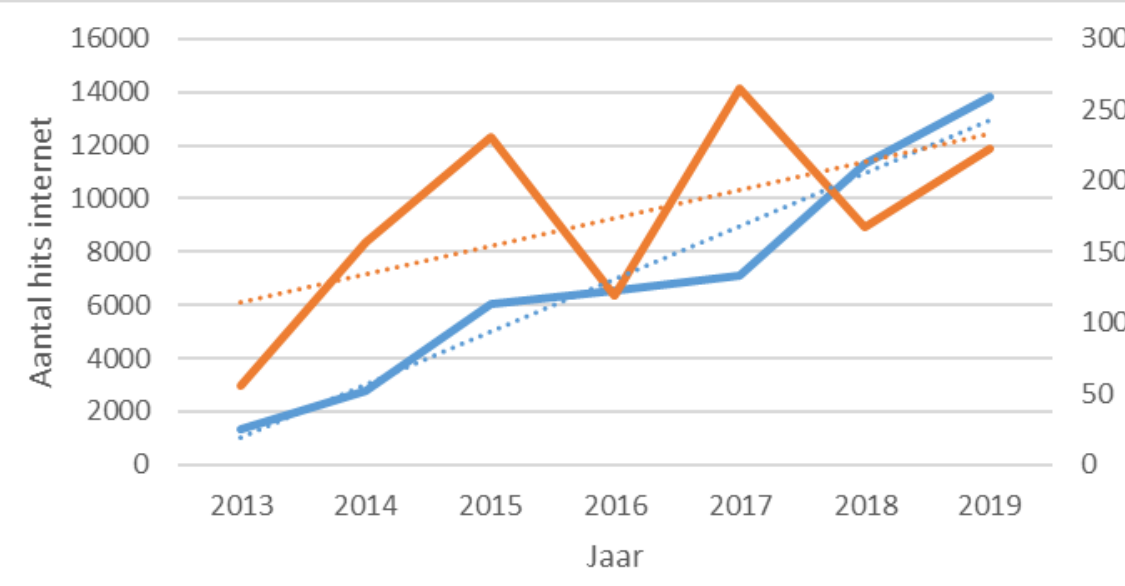

Figuur 34 Aandacht voor plastic soep in het nieuws (weergegeven door de blauwe lijn als aantal google hits op de zoektermen 'plastic soep soup' per jaar, linker $y$-as) en de motivatie om daar iets aan te doen (weergegeven door de oranje lijn als het aantal respondenten van de Beach Clean-up die als motivatie ' iets doen aan de plastic soep' hebben opgegeven, rechter $y$-as) in de periode 20132019. Voor beide is de trend weergegeven door de stippellijnen (m.b.v. Excel functie).

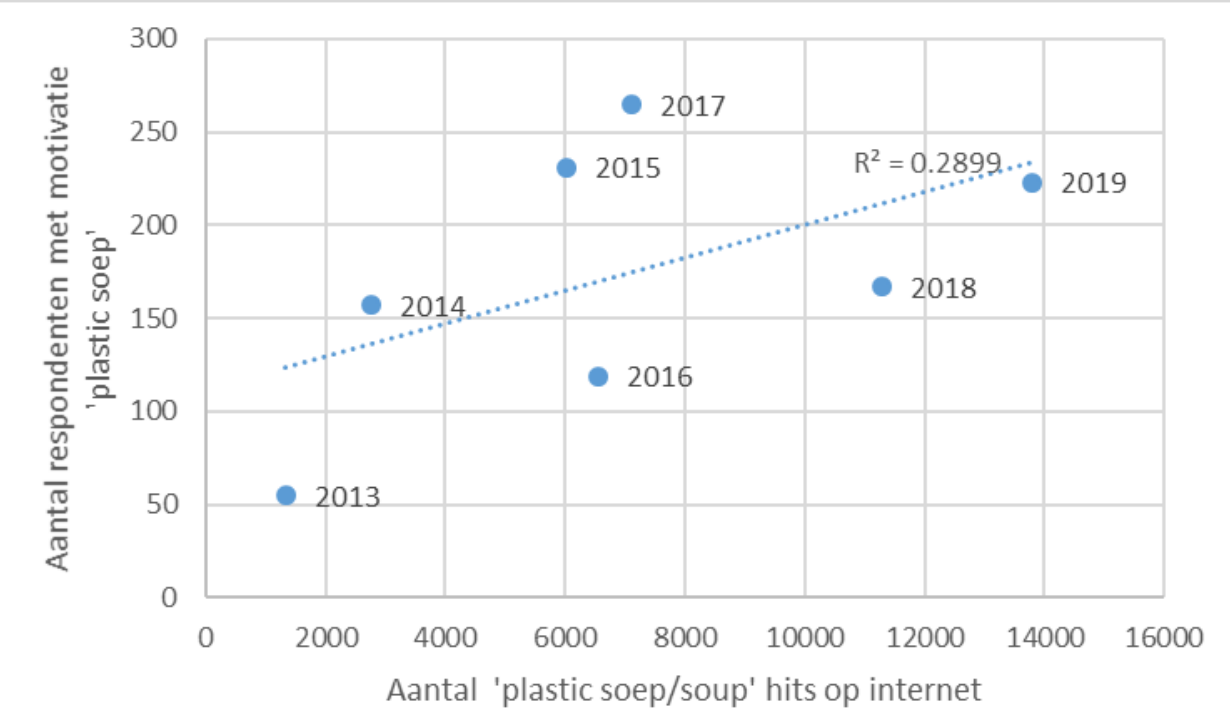

Figuur 35 Aandacht voor plastic soep in het nieuws (weergegeven als aantal google hits op de zoektermen 'plastic soep soup' per jaar, $x$-as) versus de motivatie om daar iets aan te doen (weergegeven als het aantal respondenten van de Beach Clean-up die als motivatie 'iets doen aan de plastic soep' hebben opgegeven, $y$-as) in de periode 2013-2019. De relatie is weergegeven door de stippellijn, inclusief correlatiecoëfficiënt (m.b.v. Excel functie).

\subsubsection{Invloed seizoen en weer}

Van de gevraagde respondenten in 2017-2019 heeft 68\% aangegeven ook mee te willen doen met de Beach Clean-up als dat in een ander seizoen wordt georganiseerd (Figuur 35). Een zeer klein deel (4\%) wil dat niet en de rest twijfelt of zou dat onder bepaalde omstandigheden wel willen. In 2017 is ook gevraagd of het weer invloed heeft op de deelname: "Zou je ook het strand willen schoonmaken bij slecht(er) weer?". Daarop heeft $84 \%$ met "ja" geantwoord. 

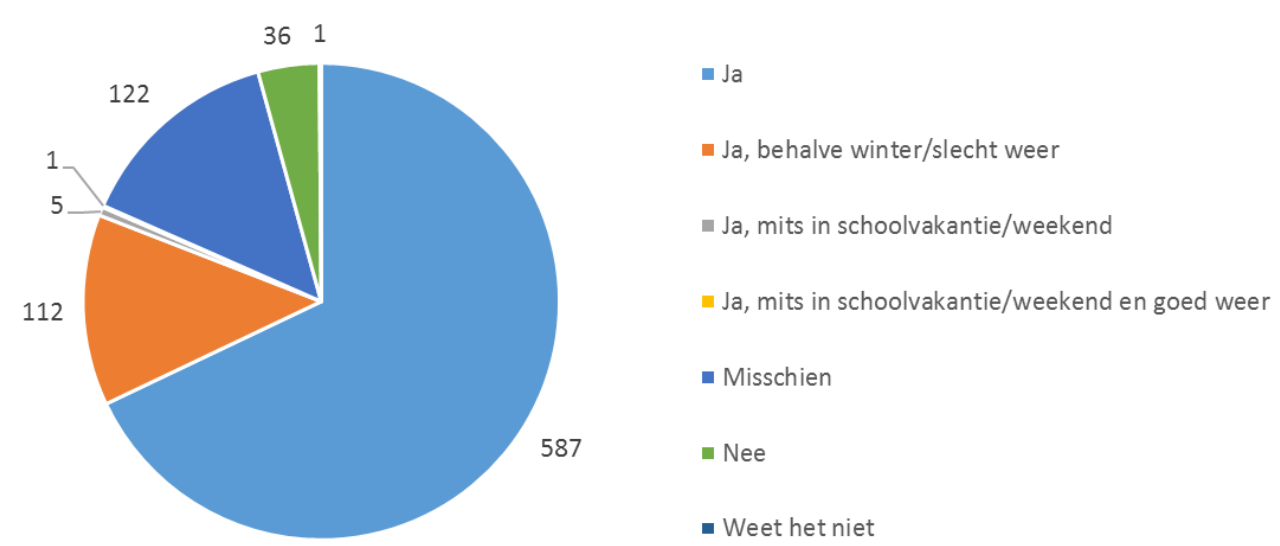

Figuur 36 Het aantal respondenten van de Beach Clean-up die hebben aangegeven met antwoorden op de vraag of ze ook in een ander seizoen mee zouden willen doen.

\subsubsection{Volgend jaar weer?}

Verreweg de meeste deelnemers hebben aangegeven volgend jaar weer mee te willen (Figuur 36). Dit betekent echter niet dat ze dit ook daadwerkelijk hebben gedaan, aangezien het aantal respondenten in 2017 dat volgend jaar weer mee zou willen doen groter is dan het aantal deelnemers in 2018. Het jaar daarop zou dit wel het geval kunnen zijn. Deze vraag is alleen in $2017 \mathrm{t} / \mathrm{m} 2019$ gesteld waardoor er geen andere jaren kunnen worden vergeleken. Wel is in 2015 gevraagd in welke jaren de respondent heeft meegedaan. Op basis daarvan blijkt dat $72 \%$ één jaar heeft meegedaan (alleen in 2015), 18\% 2 jaar en 10\% heeft alle drie de jaren meegedaan.

In 2019 is gevraagd of men plezier heeft gehad in de deelname. Daarop heeft slechts 1 respondent met nee geantwoord. Bijna iedereen heeft dus plezier gehad, waarvan $21 \%$ heeft aangegeven dat dit boven verwachting was.

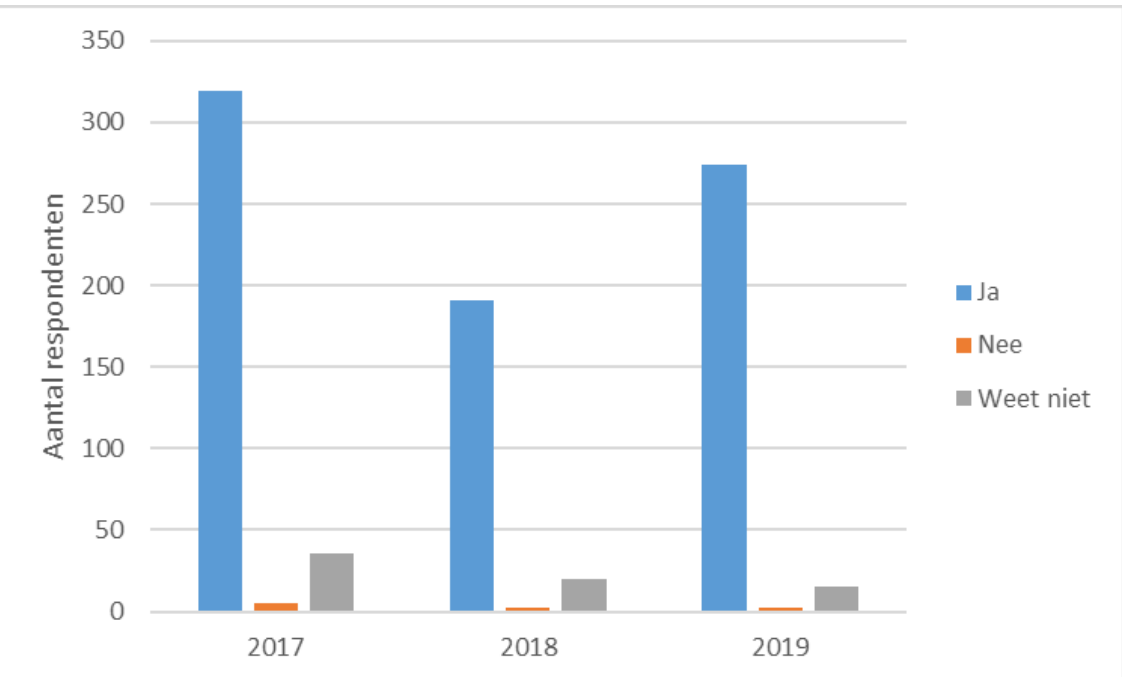

Figuur 37 Het aantal respondenten van de Beach Clean-up in 2017, 2018 en 2019 die hebben aangegeven volgend jaar weer mee te willen doen (blauwe balk, 'ja'), het aantal die dat niet willen (oranje balk, 'nee') en het aantal die dat nog niet weten of twijfelen (grijze balk, 'weet niet'). 


\subsection{Extra vragen burgerbetrokkenheidsonderzoek (2019)}

\subsubsection{Betrokkenheid bij het milieu}

$62 \%$ van de deelnemers geeft aan tijdens thuis of in hun vrije tijd ook betrokken te zijn bij op het milieu gerichte initiatieven (Figuur 37). Voorbeelden die deelnemers hierbij geven zijn bijvoorbeeld het opruimen van afval op straat, het scheiden van afval, vegetarisch of biologisch eten en het doen van vrijwilligerswerk in de natuur. Ook steunen deelnemers groene initiatieven op financieel vlak, doen ze aan natuurvriendelijk tuinieren of zijn ze lid van een politieke partij die zich bezig houdt met milieu.

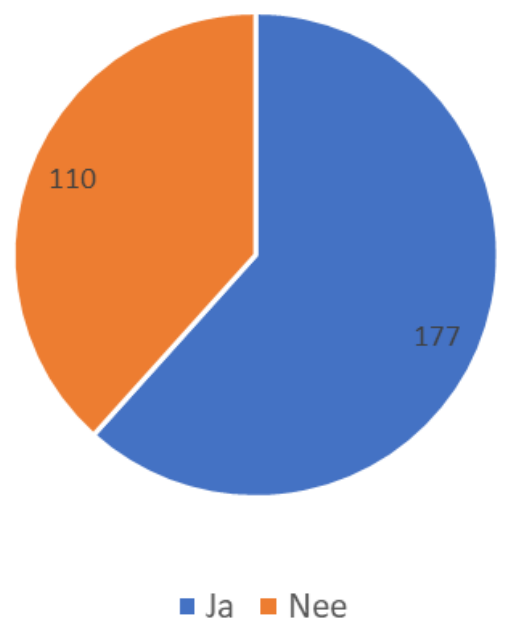

Figuur 37 Het aantal respondenten van de Beach Clean-up in 2019 dat heeft aangegeven of zij naast deelname aan de Beach Clean-up ook op andere manieren betrokken zijn met op het milieu gerichte initiatieven. Ja (blauwe deel), Nee (oranje deel).

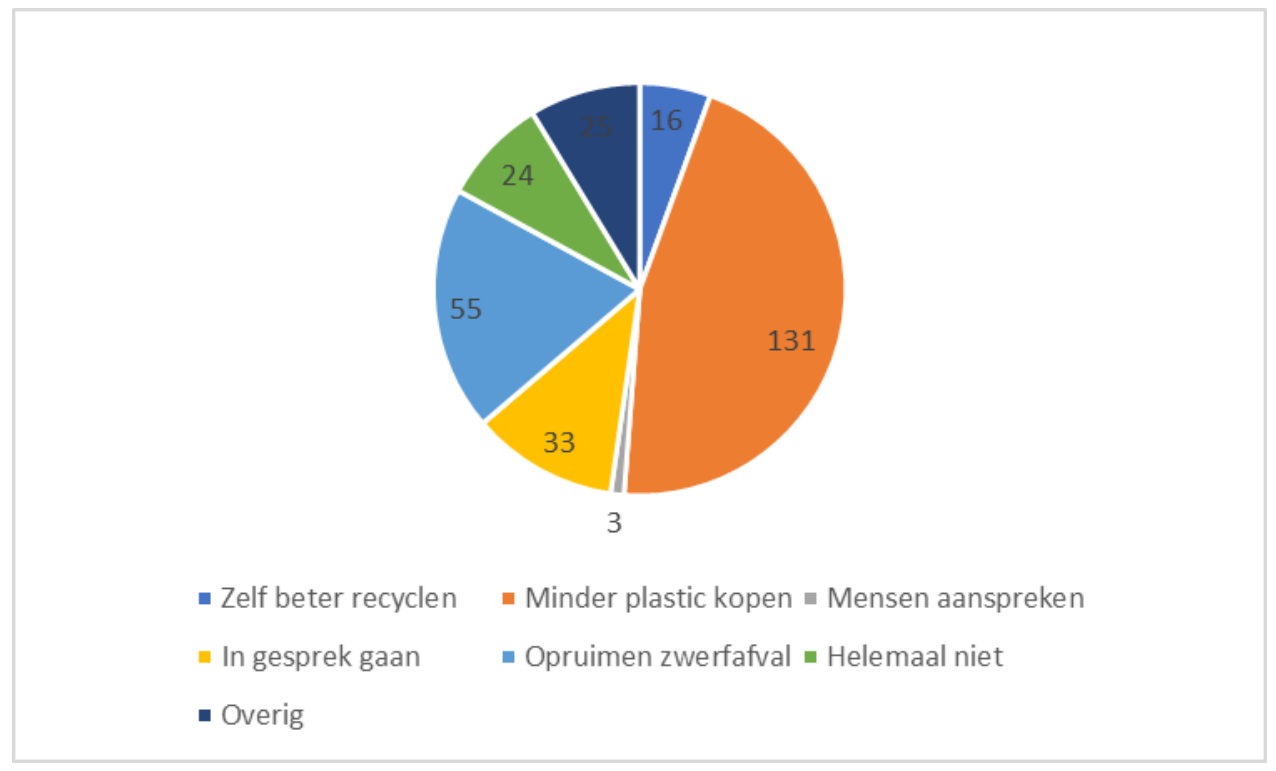

Figuur 39 Het aantal respondenten van de Beach Clean-up in 2019 per antwoord op de vraag of zij in hun dagelijks leven anders met (zwerf)afval omgaan na deelname aan de Clean-Up. Bijvoorbeeld door zelf beter te recyclen (middel blauwe deel), minder plastic te kopen (oranje deel), mensen aanspreken die afval op straat gooien (grijze deel), in gesprek te gaan met familie en vrienden (gele deel), zelf zwerfafval op te ruimen (licht blauwe deel). Ook zijn er deelnemers die niet anders omgaan met zwerfafval na deelname ('helemaal niet', groene deel) of andere opties aangaven ('overig', donkerblauwe deel). 


\subsubsection{Verandering van gedrag na deelname}

$82 \%$ van de deelnemers geeft aan dat hij of zij anders met (zwerf)afval omgaat sinds zijn of haar deelname aan de Clean-Up. 46\% geeft aan minder plastic artikelen te kopen, $19 \%$ ruimt zwerfafval op op straat en $11 \%$ gaat in gesprek met vrienden en familie over dit onderwerp (Figuur 38).

\subsubsection{Bijdrage Beach Clean-up aan verminderen plastic soep}

De meeste deelnemers (74\%) hebben aangegeven dat ze denken dat de Beach Clean-up op de lange termijn bijdraagt aan het verminderen van de plastic soep. Veel respondenten hebben daarbij wel hun vraagtekens, door aan te geven dat ze hopen dat het een bijdrage levert. Ook zijn er respondenten die aangeven dat het vooral zal werken via de media-aandacht, of door toeristen die de actie opmerken, zodat mensen bewuster zullen omgaan met afval.
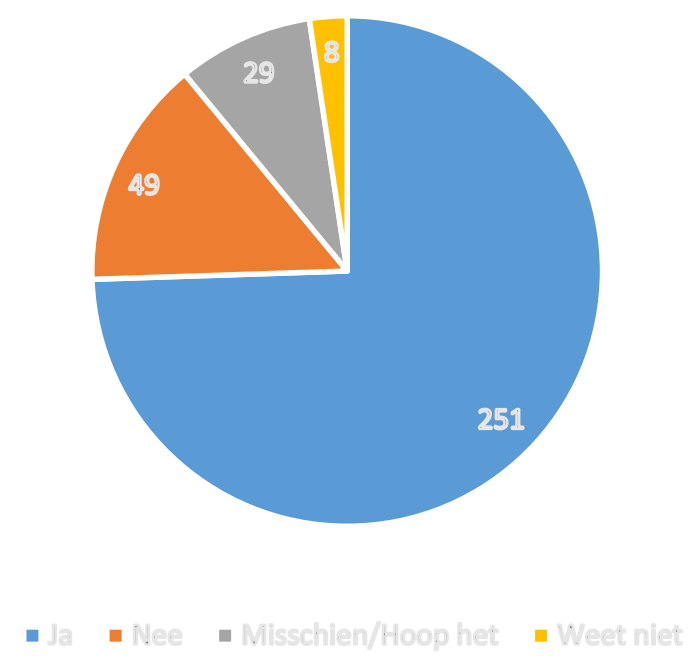

Figuur 38 Het aantal respondenten van de Beach Clean-up in 2019 die hebben aangegeven dat de Beach Clean-up bijdraagt aan het op de lange termijn verminderen van de plasticsoep (blauwe deel, 'ja'), het aantal die denken dat het geen bijdrage levert (oranje deel, 'nee'), het aantal dat denkt dat het misschien een bijdrage levert of dat hoopt (grijze deel, 'misschien/hoop het' en het aantal die dat niet weten (gele deel, 'weet niet'). 


\section{Conclusies}

Op basis van de enquêtes van de Beach Clean-up 2013-2019 zijn de volgende conclusies te trekken. Hierbij moet worden opgemerkt dat de enquêtes sterk verschillen per jaar. De resultaten geven daarom niet altijd een representatief overzicht van de hele periode.

In het jaar 2019 zijn extra vragen voor het onderzoek naar de rol van burgerbetrokkenheid in het natuurbeheer opgenomen. Hieronder worden de conclusies weergegeven uit de analyse van de jaarlijkse enquête die Stichting De Noordzee heeft gehouden (2013-2019) en voor de additionele vragen (2019).

\subsection{Conclusies jaarlijkse deelnemers enquête 2013-2019}

\subsubsection{Wat voor type mensen doe mee met de Beach Clean-up?}

- De meeste mensen bezoeken één tot enkele keren per jaar het Nederlandse strand aan de Noordzee.

- Natuur / dier(bescherming) is het meest genoemd als hobby.

- Het grootste deel van de respondenten is thuis en/of in de vrije tijd ook bezig met het milieu.

- $\quad$ De meeste waren werkzaam in de sector Zorg en gezondheid. Ongeveer $12 \%$ gaf aan niet werkzaam te zijn in een bepaalde sector en $10 \%$ van de deelnemers gaven aan gepensioneerd te zijn.

- Ruim driekwart heeft aangegeven een krant te lezen. Mail, facebook en LinkedIn waren de meest gebruikte media onder de deelnemers.

- Meer dan driekwart was ouder dan 40 jaar en de gemiddelde leeftijd was ongeveer 50 jaar. Slechts 8 tot $9 \%$ van de deelnemers was jonger dan 30 jaar.

- De verdeling tussen mannen en vrouwen is redelijk gelijk.

- De helft van de deelnemers gaf aan een partner te hebben en ongeveer een derde was single. De meeste deelnemers (61\%) hebben geen kinderen. Bij de deelnemers die wel kinderen hebben zijn de kinderen meestal ouder dan 12 jaar.

\subsubsection{Waar komen de deelnemers vandaan?}

De meeste deelnemers komen uit Noord- en Zuid Holland (ieder ca. 35\%). Dit is te verwachten aangezien deze provincies aan de Noordzeekust liggen. Andere Noordzeekustprovincies (Zeeland, Friesland) scoren echter veel lager (ruim 2\%). Van de binnenlandse provincies komt een relatief hoog percentage deelnemers uit Utrecht (ruim 10\%). Enkele deelnemers komen uit het buitenland (België en Zweden).

\subsubsection{Welke etappes worden gelopen?}

Van het gemiddeld aantal deelnemers over de periode 2013-2019 heeft etappe 25 (Vlieland) het minimum aantal deelnemers en etappe 19 (Petten) het maximum aantal deelnemers. De populairste etappes liggen in Zuid Holland gevolgd door Noord Holland. De etappes in Zeeland en Friesland zijn een stuk minder populair. Dit komt overeen met de herkomst van de deelnemers; de meeste mensen komen uit Zuid- en Noord Holland.

\subsubsection{Hoe ver reizen de deelnemers?}

De reisafstand is bepaald op basis van de afstand tussen de opgegeven woonplaats en de plaats behorende bij de eerst genoemde etappe. Hierbij is aangenomen dat iedere deelnemer vanaf de woonplaats reist naar de eerst opgegeven etappe. Deze analyse is gebaseerd op de gegevens uit 
2016. $\mathrm{Er}$ is een grote variatie in reisafstand met een minimum van ca. $10 \mathrm{~km}$ en een maximum van $338 \mathrm{~km}$. De maximale afstand was voor een deelnemer uit België, die hier waarschijnlijk op vakantie was. De grootste afstand onder Nederlanders was $311 \mathrm{~km}$. De gemiddelde reisafstand was $125 \mathrm{~km}$ per deelnemer.

\subsubsection{Met welk vervoersmiddel?}

De meeste deelnemers (ruim 60\%) zijn met de auto naar de Beach Clean-up gekomen en ongeveer $20 \%$ met het openbaar vervoer.

\subsubsection{Zijn de deelnemers speciaal voor de Beach Clean-up gekomen?}

Het percentage respondenten dat heeft aangegeven speciaal naar de Beach Clean-up te zijn gereisd varieert tussen de 31 en $88 \%$ met een gemiddelde van $64 \%$. Het grootste deel van de deelnemers reist er dus speciaal naar toe. Andere deelnemers hebbe aangegeven in de buurt te zijn of de deelname te combineren met andere doeleinden zoals vakantie of familiebezoek.

\subsubsection{Hebben ze daarvoor een vrije dag genomen?}

Meer dan een derde van de respondenten hebben een vrije dag genomen van het werk om mee te kunnen doen. Deze vraag is alleen in 2017 t/m 2019 gesteld. Er is een stijging in het aandeel van de mensen die een vrije dag hebben genomen ten opzichte van degene die dat niet hebben gedaan (of niet hebben hoeven doen). In 2017 was de verhouding wel/geen vrije dag 0.36, in 2017 was dat 0.37 en in 2019 was de verhouding 0.43 .

\subsubsection{Wat was de motivatie om mee te doen?}

Iets doen aan de plastic soep is in bijna alle jaren het meest genoemd wordt als motivatie. De motivatie 'plastic soep' ten opzichte van alle motivaties varieert van 30\% (2013) tot 76\% (2014). De laatste jaren (2017 t/m 2019) is het aandeel vrij stabiel en varieert tussen de $41 \%$ en $44 \%$. De motivatie heeft een stijgende trend over de periode 2013-2019. Ook de aandacht voor plastic soep in het nieuws neemt toe in deze periode. Relatief gezien laat de verandering van de motivatie over de jaren een ander beeld zien, waarbij de motivatie 'Plastic soep' relatief per antwoord een dalende trend laat zien en relatief per respondent een neutrale trend. Relatief gezien is de motivatie voor een schoon strand en actie te ondernemen sterk gestegen van 2013 tot 2019.

Sinds 2017 hebben de motivaties in de categorie 'opruimen, schoon strand, actie ondernemen' een belangrijk aandeel, terwijl dat in de periode 2013-2016 nauwelijks een rol speelde.

$\mathrm{Er}$ is een stijgende trend in de verhouding natuur- versus mensgerichte (sportief/gezellig) motivatie. De natuur lijkt dus een steeds grotere rol te spelen voor mensen om in actie te komen.

Verreweg de meeste deelnemers hebben aangegeven volgend jaar weer mee te willen doen. Bijna iedereen heeft plezier gehad, waarvan $21 \%$ heeft aangegeven dat dit boven verwachting was.

\subsection{Extra vragen onderzoek Burgerbetrokkenheid}

\subsubsection{Betrokkenheid bij milieu naast deelname Clean-Up}

$62 \%$ van de deelnemers geeft aan naast hun deelname aan de Clean-Up ook op andere manieren betrokken te zijn bij het milieu. Deelnemers ruimen bijvoorbeeld afval op straat, scheiden hun afval of doen vrijwilligers in de natuur. Sommige deelnemers geven aan dat ze vegetarisch of biologisch eten ten behoeve van het milieu en dat ze lid zijn van een politieke partij die zich richt op natuur- en milieubescherming. Ook geven deelnemers aan dat ze groene doelen steunen, of in hun eigen tuin natuurvriendelijk tuinieren. 


\subsubsection{Verandering van gedrag met betrekking tot (zwerf)afval}

$82 \%$ van de deelnemers geeft aan dat hij of zij anders met (zwerf)afval omgaat sinds zijn of haar deelname aan de Clean-Up. De verandering die bij de meeste deelnemers plaatsvindt is het kopen van minder plastic artikelen. Daarnaast ruimen mensen zwerfafval op op straat of gaan in gesprek over de plastic soep. Slechts een klein deel van de deelnemers geeft aan mensen op straat aan te spreken wanneer deze afval op straat gooien (1\%).

\subsubsection{Bijdrage aan oplossen van de plastic soep}

Een groot deel van de deelnemers (74\%) denkt dat zijn of haar deelname aan de Beach Clean-Up op de lange termijn bijdraagt aan het verminderen van de plastic soep. Deelnemers geven echter ook aan dat ze vooral hopen dat het een bijdrage leveren, of dat het een druppel op de gloeiende plaat is. Vooral bewustwording en toenemende media aandacht wordt gezien als iets dat gestimuleerd wordt door de Clean-Up, wat kan leiden tot ander beleid (bijvoorbeeld statiegeld op kleine flesjes).

\subsection{Aanbevelingen}

De analyse van de deelnemers enquête van de Boskalis Beach Clean-up heeft een schat aan informatie opgeleverd over de kenmerken en motivaties van de deelnemers in de periode 2013-2019. Daarnaast biedt de enquête de mogelijkheid om ook de ervaringen van de deelnemers rond de organisatie en logistiek te analyseren. Deze vragen over deze onderwerpen zijn niet meegenomen in deze analyse, omdat deze buiten de scope van het Kennisbasis-project 'Citizens for Biodiversity' vallen.

Voor het uitvoeren van de analyse over de periode 2013-2019 is veel tijd gaan zitten in het harmoniseren van de vragen. De formulering van de vragen verschilde veelal van jaar tot jaar, waardoor deze niet zonder harmonisatie vergeleken konden worden. Daarnaast waren er veel open vragen, die voor de analyse in antwoord categorieën zijn gerubriceerd. Ook dit was tijdsintensief en zorgt voor onzekerheid vanwege mogelijke interpretatiefouten. Voor de toekomstige deelnemers enquête hebben wij twee aanbevelingen om de enquêteresultaten op een eenvoudigere manier, met minder inspanning en zorgt voor onzekerheid vanwege mogelijke interpretatiefouten beschikbaar te maken.

1. Werk met vaste basisvragen die bij voorkeur in dezelfde volgorde worden gesteld;

2. Werk zoveel mogelijk met een 'meerkeuzesysteem' met vaste antwoord categorieën (met eventueel een aanvullende optie: 'anders, namelijk...'). Dit geeft na afloop van de enquête direct inzicht in de verdeling van de antwoordenmogelijkheden per vraag.

De geharmoniseerde vragen en de categorisering van antwoorden voor de analyse in deze rapportage kunnen hierbij als handvat gebruikt worden. 


\section{Kwaliteitsborging}

Wageningen Marine Research beschikt over een ISO 9001:2015 gecertificeerd kwaliteitsmanagementsysteem. Dit certificaat is geldig tot 15 december 2021. De organisatie is gecertificeerd sinds 27 februari 2001. De certificering is uitgevoerd door DNV GL. 


\section{Literatuur}

Kennisonline (2019). Rol burgers in natuurbeheer. https://www.wur.nl/nl/OnderzoekResultaten/Onderzoeksprojecten-LNV/Expertisegebieden/kennisonline/Rol-burgers-innatuurbeheer.htm (geraadpleegd 4 mei 2020). 


\section{Verantwoording}

Rapport C046/20

Projectnummer: KB-36-005-001

Dit rapport is met grote zorgvuldigheid tot stand gekomen. De wetenschappelijke kwaliteit is intern getoetst door een collega-onderzoeker en het verantwoordelijk lid van het managementteam van Wageningen Marine Research.

Akkoord:

Dr. ir. N.A. Steins

Onderzoeker

Handtekening:

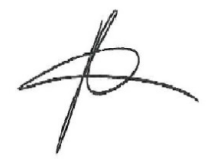

Datum:

15 mei 2020

Akkoord:

Drs. J. Asjes

Manager Integratie

Handtekening:

Datum:

15 mei 2020 


\section{Bijlage 1 Enquêtevragen}

Tabel 11 Overzicht van de enquêtevragen over de Beach clean-up tour 2013 t/m 2019 . Om vergelijking mogelijk te maken zijn de oorspronkelijke vragen iets aangepast tot een uniforme opzet.

\begin{tabular}{|c|c|c|c|c|c|c|c|}
\hline Enquêtevragen & $\stackrel{m}{\stackrel{n}{0}}$ & $\stackrel{4}{\stackrel{4}{0}}$ & $\stackrel{\text { กิ }}{n}$ & $\stackrel{\text { No }}{\circ}$ & సิ & $\stackrel{\infty}{\stackrel{\infty}{0}}$ & कृ \\
\hline \multicolumn{8}{|l|}{ Meegenomen in de analyse } \\
\hline \multicolumn{8}{|l|}{ Categorie: Motivatie } \\
\hline $\begin{array}{l}\text { Bent u thuis of in uw vrije tijd ook betrokken bij andere op het milieu gericht } \\
\text { initiatieven? }\end{array}$ & & & & & & & 1 \\
\hline \multicolumn{8}{|l|}{$\begin{array}{l}\text { Denkt u dat uw meehelpen aan de Beach Clean-up Tour bijdraagt aan het op de } \\
\text { lange termijn verminderen van de plasticsoep? }\end{array}$} \\
\hline Heb je een dag vrij genomen om deel te nemen aan dit evenement? & & & & & 1 & 1 & 1 \\
\hline $\begin{array}{l}\text { Heeft het weer invloed op jouw deelname? Zou je ook het strand willen } \\
\text { schoonmaken bij slecht(er) weer? }\end{array}$ & & & & & 1 & & \\
\hline \multicolumn{8}{|l|}{$\begin{array}{l}\text { Hoe groot is de kans dat je Boskalis Beach Clean-up Tour aanbeveelt bij } \\
\text { vrienden, familie en/of collega's? }\end{array}$} \\
\hline Wat is jouw belangrijkste motivatie geweest om met een etappe mee te helpen? & 1 & 1 & 1 & 1 & 1 & 1 & 1 \\
\hline Wil je volgend jaar weer meedoen? & & & & & 1 & 1 & 1 \\
\hline Zou je de Beach Clean-up Tour aanraden aan anderen? & & & & & 1 & 1 & 1 \\
\hline $\begin{array}{l}\text { Zou je ook meedoen als we de Beach Clean-up Tour in een ander seizoen zouden } \\
\text { organiseren? }\end{array}$ & & & & & 1 & 1 & 1 \\
\hline \multicolumn{8}{|l|}{ Categorie: Persoonlijk (hobby, werk, gezin, etc.) } \\
\hline Hoe vaak bezoek je gemiddeld het Nederlandse strand aan de Noordzee? & & & 1 & & & & \\
\hline In welke categorie valt jouw hobby? (Meerdere antwoorden mogelijk) & & & 1 & & & & \\
\hline In welke sector ben je werkzaam? (Meerdere antwoorden mogelijk) & & & 1 & & & & \\
\hline Lees je een krant? Zo ja welke: (Meerdere antwoorden mogelijk) & & & 1 & & & & \\
\hline Van welke (social) media maak je gebruik? (Meerdere antwoorden mogelijk) & & & 1 & & & & \\
\hline Wat is je geboortedatum? & & & 1 & & & & \\
\hline Wat is je geslacht? & & & 1 & & & & \\
\hline Wat is je gezinssituatie? (Meerdere antwoorden mogelijk) & & & 1 & & & & \\
\hline Wat is je leeftijd? & & & & 1 & & & \\
\hline Wat is je woonplaats? & & & 1 & 1 & & & \\
\hline Wat voor opleiding(en) heb je gevolgd? (Meerdere antwoorden mogelijk) & & & 1 & & & & \\
\hline Welk(e) strand(en) en strandpaviljoen(s) bezoek je het meeste? & & & 1 & & & & \\
\hline \multicolumn{8}{|l|}{ Categorie: Waar/wanneer/hoe (jaar, welke etappe, vervoer) } \\
\hline Heb je de hele etappe of een gedeelte meegelopen? & 1 & 1 & & 1 & & & \\
\hline Hoeveel etappes heb je in totaal meegelopen? & & & 1 & & & & \\
\hline $\begin{array}{l}\text { In welk jaar heb je meegedaan aan de Beach Clean-up Tour? (Meerdere } \\
\text { antwoorden mogelijk) }\end{array}$ & & & 1 & & & & \\
\hline Met welk vervoersmiddel ben je naar de etappe gekomen? & & 1 & & 1 & & & \\
\hline Was je tijdens jouw etappe van de Beach Clean-up: & & & & & 1 & 1 & 1 \\
\hline Welke etappe(s) heb je gelopen? & 1 & 1 & & 1 & 1 & 1 & 1 \\
\hline
\end{tabular}




\section{Niet meegenomen in de analyse}

Categorie: Feedback (cijfer, tips, wat vind je van.., etc.)

Geef een algemeen cijfer voor de Beach Clean-up

Heb je algemene opmerkingen, tips of verbeterpunten voor de Beach Clean-up

Tour?

Kun je aangeven welke van onderstaande materialen je graag wilt gebruiken

tijdens een opruimactie?

Wat is volgens jou de beste maand om de tour te organiseren?

Wat verwacht je dat Stichting De Noordzee tijdens de Boskalis Beach Clean-up Tour voor jou als deelnemer organiseert

Wat vind je de beste lengte van de tour?

Wat vind je van de lengte van één etappe?

Wat vond je van de 100-meter telling (meestal aan de start van de etappe)?

Wat vond je van de begeleiding van Stichting De Noordzee?

Wat vond je van de beschikbare materialen voor deelnemers?

Wat vond je van de briefing in de ochtend?

Wat vond je van de verzamel- en starttijd

Wat vond je van het dagteam dat de Beach Clean-up begeleidde? (Toelichting bij optie 'anders')

Wat zijn jouw verwachtingen tijdens een Beach Clean-up?

Vind je dat de tour gedurende één maand moet plaatsvinden, of gedurende een kortere periode (waarbij er op één dag meerdere etappes tegelijk plaatsvinden)? Wat vond je van de informatie vooraf via de mail en website? Wat vond je van de starttijd (10.00 uur)?

Wat vond je van de informatiematerialen op de inschrijftafel?

Wat vond je van de snacks van de Plus?

Wat vond je van het petje?

Wat vond je van de 100-meter telling?

Heb je nog tips voor de begeleiding?

\section{Categorie: Overig/administratief}

Extra: Als je mee wilt doen om een KRNWTR-bidon te winnen vul dan hier jouw adres in:

Hoe heb je gehoord van de My Beach Clean-up Challenge?

Ik geef toestemming dat de gegevens van deze enquête ook gebruikt mogen worden door andere partijen dan Stichting De Noordzee voor data-analyse en onderzoek.

Indien je een pakketje wilt ontvangen in mei / juni: super! Wat is je naam + adres?

Tijdstempel

Wat is je naam?

Wat is je emailadres?

Misschien meenemen in de analyse

\section{Categorie: Feedback (cijfer, tips, wat vind je van.., etc.)}

Heb je ideeën over hoe we meer mensen kunnen enthousiasmeren om een etappe mee te lopen?

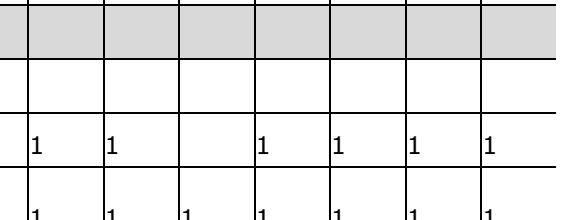

\begin{tabular}{l|l|l|l|l|l|l}
1 & 1 & 1 & 1 & 1 & 1 & 1
\end{tabular}

1

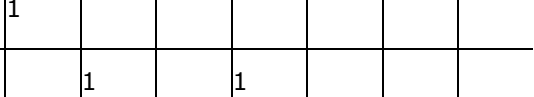

.


Als je een gedeelte hebt meegelopen, wat was de reden dat je niet de hele etappe hebt meegelopen?

Als je je wel hebt opgegeven; maar toch niet aanwezig was; kun je aangeven waarom dat was?

Heb je met plezier meegedaan?

Hoe beïnvloedt uw deelname aan de Beach Clean-up Tour de manier waarop u in uw dagelijks leven omgaat met zwerfafval?

Hoe ben je teruggekomen (aan het eind van de etappe)?

Vind je dat we met de tour de héle Noordzeekust moeten schoonmaken of dat we alleen zogenaamde 'hotspots' moeten aanpakken?

Categorie: Overig/administratief

Wil je ons helpen met de promotie van de Boskalis Beach Clean-up Tour?

\begin{tabular}{ll|l|l|l|l|l|l}
\hline & & & & 1 & 1 & 1 \\
& & & 1 & 1 & 1 \\
\hline
\end{tabular}

\begin{tabular}{l|l|l|l|l|l|l} 
& & & & & & 1 \\
\hline 1 & & & & & & \\
\hline & 1 & & 1 & & & \\
\hline 19 & 21 & 19 & 23 & 21 & 18 & 21
\end{tabular}




\section{Bijlage 2 Etappes}

De etappes van zuid naar noord in de periode 2013-2016 zijn als volgt:

$\begin{array}{ll}\text { Etappe } 1 & \text { Cadzand - Breskens } \\ \text { Etappe 2 } & \text { Vlissingen - Westkapelle } \\ \text { Etappe 3 } & \text { Domburg - Vrouwenpolder } \\ \text { Etappe 4 } & \text { Burgh Haamstede - Renesse } \\ \text { Etappe 5 } & \text { Brouwersdam, Ouddorp - Ouddorp } \\ \text { Etappe 6 } & \text { Kwade Hoek } \\ \text { Etappe 7 } & \text { Rockanje - Oostvoorne } \\ \text { Etappe 8 } & \text { Maasvlakte } \\ \text { Etappe 9 } & \text { Hoek van Holland - Monster } \\ \text { Etappe 10 } & \text { Monster - Scheveningen } \\ \text { Etappe 11 } & \text { Scheveningen - Wassenaar } \\ \text { Etappe 12 } & \text { Wassenaar - Noordwijk } \\ \text { Etappe 13 } & \text { Noordwijk - Langevelderslag } \\ \text { Etappe 14 } & \text { Langevelderslag - Zandvoort } \\ \text { Etappe 15 } & \text { Zandvoort - IJmuiden } \\ \text { Etappe 16 } & \text { Velsen-Noord - Castricum } \\ \text { Etappe 17 } & \text { Castricum - Bergen aan Zee } \\ \text { Etappe 18 } & \text { Bergen aan Zee - Camperduin } \\ \text { Etappe 19 } & \text { Petten - Callantsoog } \\ \text { Etappe 20 } & \text { Callantsoog - Den Helder } \\ \text { Etappe 21 } & \text { Texel: Paal 9 - Paal 17 } \\ \text { Etappe 22 } & \text { Texel: Paal 17 - zuidkant slufter } \\ \text { Etappe 23 } & \text { Texel: noordkant Slufter - vuurtoren } \\ \text { Etappe 24 } & \text { Vlieland: Reddingbootpad - Pad van 20 } \\ \text { Etappe 26 } & \text { Terschelling: Groene Strand - Badweg } \\ \text { Etappe 27 } & \text { Terschelling: Badweg - Oosterender Badweg } \\ \text { Etappe 28 } & \text { Terschelling: Oosterender Badweg - Noordkaap } \\ \text { Etappe 29 } & \text { Ameland: Oranjeweg - Strandweg } \\ \text { Etappe 30 } & \text { Ameland: Strandweg - Oerduinen } \\ \text { Etappe 31 } & \text { Schiermonnikoog: Badweg - Oosterzand } \\ & \end{array}$

De etappes in de periode 2017-2019 zijn:

N1 Schiermonnikoog (Paviljoen de Marlijn) - Schiermonnikoog (Paviljoen de Marlijn)

Z1 Cadzand (Moio Beach) - Groede (Paviljoen Puur)

N2 Schiermonnikoog (Paviljoen de Marlijn) - Schiermonnikoog (Paviljoen de Marlijn)

Natuurmonumenten etappe

Z2 Vlissingen (Panta Rhei) - Zoutelande (Paviljoen Zeeuwse Riviera)

N3 Ameland (Paviljoen 't Strandhuys) - Ameland (Paviljoen 't Strandhuys)

Z3 Neeltje Jans (Atlantis) - Neeltje Jans (Atlantis)

N4 Terschelling (Paviljoen Zandzeebar) - Terschelling (Paviljoen Zandzeebar)

Z4 Westenschouwen (Sand and Pepper) - Renesse (Paviljoen Zeelust) DUPI Group-etappe

N5 Terschelling (Paviljoen West aan Zee) - Terschelling (Paviljoen West aan Zee)

Z5 Brouwersdam (Natural High) - Ouddorp (Strandtent Iloon)

N6 Vlieland (Paviljoen 't Badhuys) - Vlieland (Paviljoen 't Badhuys)

Z6 Kwade Hoek 1 (Paviljoen C-side) - Kwade Hoek 1 (Paviljoen Paal 10) Natuurmonumenten etappe

N7 Texel (Paal 28) - Texel (Paal 28)

Z7 Kwade Hoek 2 (Paviljoen C-side) - Kwade Hoek 2 (Paviljoen Paal 10)

N8 Texel (Ecomare) - Texel (Paal 9) Werelderfgoed etappe

Z8 Rockanje (Beachclub Havana) - Oostvoorne (Restaurant aan Zee) 
N9 Huisduinen (Restaurant Storm aan Zee) - Grote Keeten (Paviljoen De Princen Keet)

Z9 Maasvlakte (Paviljoen Stormvogel) - Maasvlakte (Paviljoen Stormvogel) Hondenetappe

N10 Petten (Paviljoen Zee \& Zo) - Noordelijke etappe Dubbele etappe: Bultrug

N10 Petten (Paviljoen Zee \& Zo) - Zuidelijke etappe Dubbele etappe: Zeehond

Z10 Hoek van Holland (Beachclub Royal) - Monster (Bondi Beachclub) Filter etappe

N11 Hargen aan Zee (Paviljoen Hargen) - Egmond aan Zee (Nautilus aan Zee)

Z11 Monster (Bondi Beachclub) - Kijkduin (Beachclub People)

N12 Egmond aan Zee (Nautilus aan Zee) - Castricum aan Zee (Paviljoen Zeezicht)

Z12 Scheveningen (The Shore) - Wassenaar (Paviljoen Sport) Chefs voor Goede Vis etappe

N13 Castricum aan Zee (Paviljoen Zeezicht) - Wijk aan Zee (DITTIS Sunsea) Sportieve etappe

Z13 Wassenaar (Strandpaviljoen Sport) - Noordwijk (Strandpaviljoen De Zeemeeuw) Maritieme etappe

N14 Wijk aan Zee (DITTIS Sunsea) - Velsen-Noord (Paviljoen Aloha) Familiedag

Z14 Noordwijk (Koele Costa) - Langevelderslag (Strandrestaurant Nederzandt)

N15 IJmuiden (Paviljoen Noordzee) - Zandvoort (Paviljoen Ahoi) Einde NOORD • Finish en eindfeest

Z15 Langevelderslag - Zandvoort (Paviljoen Ahoi) Einde ZUID • Finish en eindfeest 


\section{Bijlage 3 Motivaties}

Tabel 12 Ingevulde motivaties ingedeeld per motivatie categorie. Per respondent zijn meerdere motivaties mogelijk

\begin{tabular}{|c|c|c|c|c|c|c|c|c|c|c|}
\hline Motivatie & 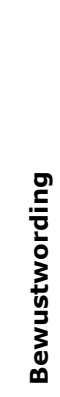 & 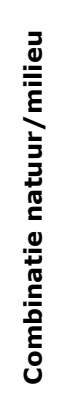 & 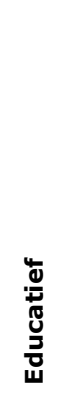 & 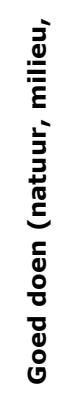 & 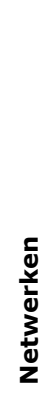 & 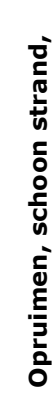 & $\frac{0}{2}$ & 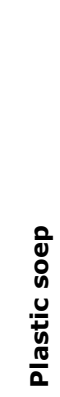 & 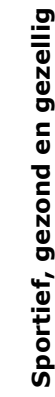 & 产 \\
\hline Aandacht vragen voor het probleem & 1 & & & & & & & & & \\
\hline Actie i.p.v. ergernis & & & & & & 1 & & & & \\
\hline $\begin{array}{l}\text { Bekenden die ik per Facebook heb uitgenodigd } \\
\text { om mee te lopen }\end{array}$ & & & & & & & 1 & & & \\
\hline Bewustwording van 'hun' strand. & 1 & & & & & & & & & \\
\hline $\begin{array}{l}\text { Broertje helpen met maatschappelijk project voor } \\
\text { school }\end{array}$ & & & & & & & 1 & & & \\
\hline De fysieke uitdaging & & & & & & & & & 12 & \\
\hline $\begin{array}{l}\text { De wens vrijwilligerswerk te doen met ons gezin } \\
\text { tijdens vakantie }\end{array}$ & & & & 1 & & & & & & \\
\hline $\begin{array}{l}\text { Dus mijn persoonlijke motivatie had geen invloed } \\
\text { op het meelopen. }\end{array}$ & & & & 1 & & & & & & \\
\hline $\begin{array}{l}\text { Een gezellig dagje met vriend(en) / familie op het } \\
\text { strand }\end{array}$ & & & & & & & & & 19 & \\
\hline Even niet alleen zijn & & & & & & & & & 1 & \\
\hline Het was een bewolkte dag (in het begin) & & & & & & & 1 & & & \\
\hline Iets concreets doen tegen de plastic soep in zee & & & & & & & & 1 & & \\
\hline Iets om handen hebben om te doen & & & & & & & 1 & & & \\
\hline Ik houd van een sportieve uitdaging & & & & & & & & & 66 & \\
\hline Ik vind het geschikt als uitje met collega's & & & & & & & & & & 13 \\
\hline Ik vind het geschikt als uitje met familie & & & & & & & & & 26 & \\
\hline Ik vind het geschikt als uitje met vrienden & & & & & & & & & 36 & \\
\hline $\begin{array}{l}\text { Ik vind het leuk om aan een strandactiviteit mee } \\
\text { te doen in de zomervakantie }\end{array}$ & & & & & & & & & 91 & \\
\hline $\begin{array}{l}\text { Ik wil bijdragen aan oplossingen voor de plastic } \\
\text { soep in zee }\end{array}$ & & & & & & & & 34 & & \\
\hline Ik wil niet alleen maar praten over dat er vuil ligt & & & & & & 1 & & & & \\
\hline Ik wilde graag iets gezonds doen & & & & & & & & & 14 & \\
\hline Inzicht verwerven & 1 & & & & & & & & & \\
\hline Leuk en educatief & & & 1 & & & & & & & \\
\hline Maar ook actie ondernemen & & & & & & 1 & & & & \\
\hline
\end{tabular}


Motivatie

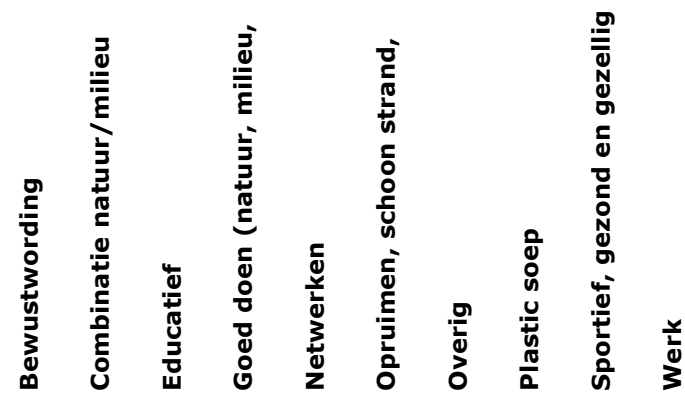

\begin{tabular}{|c|c|c|c|c|c|c|c|c|c|c|}
\hline Meehelpen rommel op te ruimen & & & & & & 1 & & & & \\
\hline Mijn jonge kinderen meegenomen & & & & & & & 1 & & & \\
\hline $\begin{array}{l}\text { Netwerken met de mensen achter My Beach } \\
\text { (vanuit Ghost Fishing) }\end{array}$ & & & & & 1 & & & & & \\
\hline $\begin{array}{l}\text { Omdat hij een spreekbeurt over plastic soep had } \\
\text { gehouden op school }\end{array}$ & & & & & & & 1 & & & \\
\hline $\begin{array}{l}\text { Voor mij was het ook een heerlijke } \\
\text { strandwandeling met een missie. }\end{array}$ & & 1 & & & & & & & & \\
\hline Wandelen en een dagje strand & & & & & & & & & 1 & \\
\hline $\begin{array}{l}\text { Wellicht iets bewuster gemaakt. Daarnaast was } \\
\text { het heel leuk om eens niet helemaal alleen } \\
\text { rotzooi op het strand te ruimen. }\end{array}$ & & & & & & 1 & & & & \\
\hline Werk gerelateerd & & & & & & & & & & 1 \\
\hline Wilde zelf meemaken wat de clean-up in hield & & & & & & & 1 & & & \\
\hline Artikel voor de krant & & & & & & & 1 & & & \\
\hline $\begin{array}{l}\text { Belangrijk om bij te dragen. Aantal deelnemers in } \\
\text { Cadzand is al jaren minimaal. }\end{array}$ & 1 & & & & & & & & & \\
\hline Bewustzijn creëren bij anderen & 1 & & & & & & & & & \\
\hline $\begin{array}{l}\text { Bijdragen aan oplossingen voor de plastic soep in } \\
\text { zee en bewustwording van zwerfafval op het } \\
\text { strand }\end{array}$ & 1 & & & & & & & & & \\
\hline Combinatie van zwerfafval opruimen & & & & & & 1 & & & & \\
\hline $\begin{array}{l}\text { Combinatie: dagje strand, opruimen iets gezonds } \\
\text { doen }\end{array}$ & & 1 & & & & & & & & \\
\hline Dagje met collega's & & & & & & & & & & 1 \\
\hline $\begin{array}{l}\text { De combi.. Fysiek en een bijdrage leveren om } \\
\text { troep op te ruimen. }\end{array}$ & & 1 & & & & & & & & \\
\hline $\begin{array}{l}\text { De combinatie van bijdragen aan het milieu, een } \\
\text { dag op het strand én iets gezonds doen. }\end{array}$ & & 1 & & & & & & & & \\
\hline De fysieke uitdaging & & & & & & & & & 2 & \\
\hline $\begin{array}{l}\text { De fysieke uitdaging, ik wilde graag iets gezonds } \\
\text { doen }\end{array}$ & & & & & & & & & 1 & \\
\hline De hond een leuke dag bezorgen & & & & & & & & & 1 & \\
\hline $\begin{array}{l}\text { Deelname aan een goed doel en een inspiratie en } \\
\text { voorbeeld voor anderen om hun levensstijl te } \\
\text { veranderen en positief mee te dragen aan de } \\
\text { vervuiling van onze mooie wereld }\end{array}$ & 1 & & & & & & & & & \\
\hline Dorian meehelpen ;) & & & & & & & 1 & & & \\
\hline Een actieve stranddag & & & & & & & & & 131 & \\
\hline Een dagje op het strand & & & & & & & & & 10 & \\
\hline
\end{tabular}




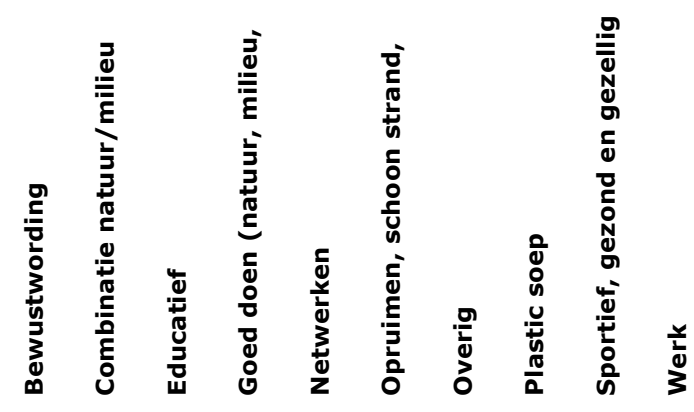

\begin{tabular}{|c|c|c|c|c|c|c|c|c|c|c|}
\hline $\begin{array}{l}\text { Een gezellig dagje met vriend(en) / familie op het } \\
\text { strand }\end{array}$ & & & & & & & & & 1 & \\
\hline $\begin{array}{l}\text { Een gezellig dagje met vrienden / familie op het } \\
\text { strand }\end{array}$ & & & & & & & & & 9 & \\
\hline $\begin{array}{l}\text { Een gezellige actieve dag op een Waddeneiland en } \\
\text { tevens wat aan de troep doen }\end{array}$ & & 1 & & & & & & & & \\
\hline Een gezellige en educatieve stranddag & & & & & & & & & 114 & \\
\hline Een leermomentje voor mijn dochter & & & 1 & & & & & & & \\
\hline Een schoon strand, zonder menselijk afval & & & & & & 1 & & & & \\
\hline $\begin{array}{l}\text { En het statement maken: kijk hoeveel rommel we } \\
\text { vinden }\end{array}$ & 1 & & & & & & & & & \\
\hline Ergernis inzetten in iets nuttigs & & & & & & 1 & & & & \\
\hline Gewoon een dagje aan het strand & & & & & & & & & 1 & \\
\hline $\begin{array}{l}\text { Gewoon een dagje aan het strand; even niet } \\
\text { alleen zijn; iets om handen hebben om te doen; } \\
\text { het was een bewolkte dag (in het begin); iets } \\
\text { concreets doen tegen de plastic soep in zee; }\end{array}$ & & & & & & & & & 1 & \\
\hline Gewoon vuilrapen op t strand & & & & & & 1 & & & & \\
\hline Het strand schoonmaken & & & & & & 1 & & & & \\
\hline $\begin{array}{l}\text { Het strand schoonmaken als eerbetoon aan mijn } \\
\text { paso verleden vriendin }\end{array}$ & & & & & & 1 & & & & \\
\hline Iets doen aan de Plastic Soep & & & & & & & & 265 & & \\
\hline Iets doen aan de plasticsoep & & & & & & & & 390 & & \\
\hline Iets doen en mijn kinderen bewust maken & 1 & & & & & & & & & \\
\hline Iets goeds doen & & & & 1 & & & & & & \\
\hline $\begin{array}{l}\text { Iets nuttigs doen gecombineerd met dagje eruit } \\
\text { en mensen leren kennen }\end{array}$ & & 1 & & & & & & & & \\
\hline $\begin{array}{l}\text { Iets terug doen voor het plezier wat ik met mijn } \\
\text { gezin jaarlijks aan het strand beleef }\end{array}$ & & & & 1 & & & & & & \\
\hline $\begin{array}{l}\text { Ik heb voor het vierde jaar meegelopen, ik kom } \\
\text { verder nooit op het strand. Opruimen vond ik een } \\
\text { leuk initiatief. }\end{array}$ & & & & & & 1 & & & & \\
\hline Ik houd van een sportieve uitdaging & & & & & & & & & 5 & \\
\hline $\begin{array}{l}\text { Ik houd van wandelen en woon in de buurt. Dit is } \\
\text { een mooie manier om het aangename met het } \\
\text { nuttige te combineren }\end{array}$ & & 1 & & & & & & & & \\
\hline $\begin{array}{l}\text { Ik ruim wekelijks delen van het strand op, en nu } \\
\text { met heel veel mensen tegelijk, leuk en nuttig! }\end{array}$ & & 1 & & & & & & & & \\
\hline Ik vind het geschikt als uitje met collega's & & & & & & & & & & 8 \\
\hline Ik vind het geschikt als uitje met familie & & & & & & & & & 1 & \\
\hline Ik vind het geschikt als uitje met vrienden & & & & & & & & & 1 & \\
\hline
\end{tabular}




\begin{tabular}{|c|c|c|c|c|c|c|c|c|c|c|}
\hline $\begin{array}{l}\text { Ik vind het leuk om aan een strandactiviteit mee } \\
\text { te doen in de zomervakantie }\end{array}$ & & & & & & & & & 9 & \\
\hline $\begin{array}{l}\text { Ik wil bijdragen aan oplossingen voor de plastic } \\
\text { soep in zee }\end{array}$ & & & & & & & & 296 & & \\
\hline Ik wil graag iets goeds doen voor de natuur & & & & 64 & & & & & & \\
\hline Ik wil iets doen aan de plastic soep & & & & & & & & 231 & & \\
\hline $\begin{array}{l}\text { Kijken waar mijn grens ligt en hoever ik er } \\
\text { overheen kan gaan }\end{array}$ & & & & & & & 1 & & & \\
\hline Lekker op het strand én nuttig bezig & & 1 & & & & & & & & \\
\hline $\begin{array}{l}\text { Leuk om met gelijkgestemden de rommel op het } \\
\text { strand op te ruimen }\end{array}$ & & 1 & & & & & & & & \\
\hline Lid van het Specific team & & & & & & & 1 & & & \\
\hline Liefde voor de natuur & & & & 1 & & & & & & \\
\hline Marchien & & & & & & & 1 & & & \\
\hline $\begin{array}{l}\text { Met collega`s een bijdrage leveren aan jullie } \\
\text { mooie initiatief en dagje uitwaaien! }\end{array}$ & & 1 & & & & & & & & \\
\hline Met collega's het strand opruimen & & & & & & & & & & 1 \\
\hline Met kind en kleinkinderen & & & & & & & 1 & & & \\
\hline Met medestanders het strand opruimen & & & & & & 387 & & & & \\
\hline Mijn strand schoonmaken & & & & & & 1 & & & & \\
\hline Mijn vrienden & & & & & & & & & 1 & \\
\hline Mijn zoon wilde meelopen & & & & & & & 1 & & & \\
\hline MVO bezig zijn & & & & 1 & & & & & & \\
\hline Netwerken & & & & & 1 & & & & & \\
\hline $\begin{array}{l}\text { Nuttige (strand ruimen) combineren met } \\
\text { aangename (strand en vrienden) }\end{array}$ & & 1 & & & & & & & & \\
\hline $\begin{array}{l}\text { Onze werkgever EMC staat toe dat wij } 3 \text { dagen per } \\
\text { jaar betaald aan een goed doel te besteden. }\end{array}$ & & & & & & & & & & 1 \\
\hline Opruimen van het strand & & & & & & 1 & & & & \\
\hline Opruimen, netwerken en singles ontmoeten. & & 1 & & & & & & & & \\
\hline Oranje handschoenen & & & & & & & 1 & & & \\
\hline Persoonlijk stil protest tegen zwerfafval & 2 & & & & & & & & & \\
\hline Samen met kids bewust worden van al het afval & 1 & & & & & & & & & \\
\hline $\begin{array}{l}\text { Samen met kleinkinderen iets leuks en educatiefs } \\
\text { doen }\end{array}$ & & & 1 & & & & & & & \\
\hline $\begin{array}{l}\text { Samen met mijn kind(eren) iets doen wat leuk én } \\
\text { educatief is }\end{array}$ & & & 22 & & & & & & & \\
\hline Signaalfunctie van het project versterken & 1 & & & & & & & & & \\
\hline Te lang voor kinderen & & & & & & & 2 & & & \\
\hline
\end{tabular}




\begin{tabular}{|c|c|c|c|c|c|c|c|c|c|c|}
\hline Motivatie & 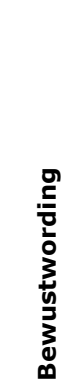 & 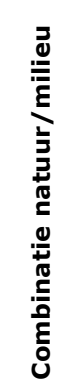 & 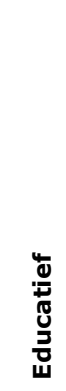 & 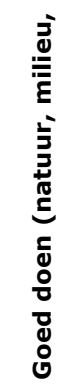 & 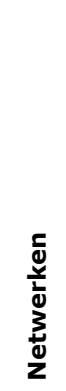 & 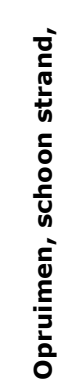 & 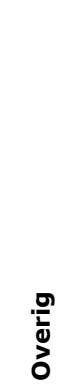 & 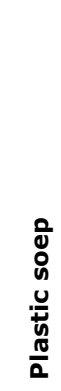 & 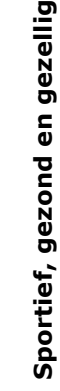 & $\begin{array}{l}\frac{r}{0} \\
3\end{array}$ \\
\hline Team activiteit van werk & & & & & & & & & & 1 \\
\hline Troep op het strand opruimen & & & & & & 1 & & & & \\
\hline Voor ons is het een kleine extra vakantie. & & & & & & & 1 & & & \\
\hline $\begin{array}{l}\text { Was een georganiseerd bedrijfsuitje; dus mijn } \\
\text { persoonlijke motivatie had geen invloed op het } \\
\text { meelopen. }\end{array}$ & & & & & & & & & & 1 \\
\hline Werk van Stichting De Noordzee ondersteunen & & & & 269 & & & & & & \\
\hline Young Boskalis & & & & & & & 1 & & & \\
\hline \multicolumn{11}{|l|}{ (Blank) } \\
\hline Grand Total & 13 & 13 & 25 & $\begin{array}{c}33 \\
9\end{array}$ & 2 & $\begin{array}{c}40 \\
2\end{array}$ & 19 & $\begin{array}{l}12 \\
17\end{array}$ & $\begin{array}{c}55 \\
4\end{array}$ & 27 \\
\hline
\end{tabular}


Wageningen Marine Research

T +31 (0)317480900

E: marine-research@wur.nl

www.wur.eu/marine-research
Wageningen Marine Research levert met kennis, onafhankelijk wetenschappelijk onderzoek en advies een wezenlijke bijdrage aan een duurzamer, zorgvuldiger beheer, gebruik en bescherming van de natuurlijke rijkdommen in zee-, kust- en zoetwatergebieden.

\section{Bezoekers adres:}

- Ankerpark 271781 AG Den Helder

- Korringaweg 7, 4401 NT Yerseke

- Haringkade 1, 1976 CP IJmuiden 